\title{
The millipede genus Antichiropus (Diplopoda: Polydesmida: Paradoxosomatidae), part 1: redefinition of the genus and redescriptions of existing species
}

\author{
Catherine A. Car ${ }^{1,4}$, Janine M. Wojcieszek ${ }^{2}$ and Mark S. Harvey ${ }^{1,3}$ \\ 1 Department of Terrestrial Zoology, Western Australian Museum, Locked Bag 49, Welshpool DC, \\ Western Australia 6986, Australia. \\ 2 School of Veterinary and Life Sciences, Murdoch University, Western Australia 6150, Australia. \\ ${ }^{3}$ Research Associate, Division of Invertebrate Zoology, American Museum of Natural History, \\ New York, U.S.A.; Research Associate, Department of Entomology, California Academy of Sciences, \\ San Francisco, California, U.S.A.; School of Animal Biology, University of WA, Crawley, \\ Western Australia 6009, Australia; School of Natural Sciences, Edith Cowan University, Joondalup, \\ Western Australia 6027, Australia. \\ ${ }^{4}$ Corresponding author: Email: catherine.ann.car@gmail.com
}

\begin{abstract}
A taxonomic review of the previously named species of the Australian endemic millipede genus Antichiropus Attems is presented. The genus is redefined and the existing nine species redescribed with lectotypes designated for seven species. New images of morphological features are included to standardise species descriptions within the genus here, and in future publications. The distribution of each species is documented.
\end{abstract}

KEYWORDS: taxonomy, short-range endemic, south-western Australia, biodiversity, morphology

\section{INTRODUCTION}

The described paradoxosomatid fauna of Australia is represented by 139 named millipede species in 40 genera (Mesibov 2013b). Knowledge of the Australian paradoxosomatid fauna is, however, extremely fragmentary and the described species represent only a small fraction of the total number of Australian species: hundreds of undescribed species have been collected in recent surveys (Car 2009; Mesibov 2008) and large tracts of Australia remain unexplored for this family of millipedes.

The described fauna of Western Australia (WA) falls into eight genera of which four represent paradoxosomatid species that have been introduced to the region, namely: Akamptogonus novarae (Humbert and de Saussure, 1869), Orthomorpha coarctata (de Saussure, 1860), Oxidus gracilis (C.L. Koch, 1847) and Solaenodolichopus pruvoti (Brolemann, 1931). The remaining four genera, Antichiropus Attems, 1911, Boreohesperus Shear, 1992, Helicopodosoma Verhoeff, 1924 and Stygiochiropus Humphreys and Shear, 1993, with one exception, occur exclusively in WA. Boreohesperus, the only member of the tribe Australiosomatini Brölemann, 1916 in WA, is represented by six species from the Cape Range area and the Pilbara region of the State, including Barrow Island (Car and Harvey 2013). The remaining genera are of the tribe Antichiropodini Brölemann, 1916. Helicopodosoma is represented only by $H$. melas Verhoeff, 1924, recorded from Kununurra $\left(15^{\circ} 46^{\prime} \mathrm{S}\right.$, $128^{\circ} 4^{\prime} \mathrm{E}$ ) and a new species from Mt Hart Station $\left(16^{\circ} 49^{\prime} \mathrm{S}, 124^{\circ} 55^{\prime} \mathrm{E}\right)$ (C. Car and M. Harvey, unpublished data). Stygiochiropus is a troglobitic genus, with all four species occurring only in caves of the Cape Range region near Exmouth (ca. $21^{\circ} 55^{\prime} \mathrm{S}, 114^{\circ} 00^{\prime} \mathrm{E}-22^{\circ} 26^{\prime} \mathrm{S}$, $114^{\circ} 07^{\prime} \mathrm{E}$ ) (Humphreys and Shear 1993). Conversely, the fourth genus, Antichiropus, is diverse, with approximately 160 new species identified (C. Car and M. Harvey, unpublished data). It is also wide ranging, occurring from the Pilbara region in the north $\left(20^{\circ} 25^{\prime} \mathrm{S}\right.$, $\left.118^{\circ} 04^{\prime} \mathrm{E}\right)$ to West Cape Howe in the south of WA $\left(35^{\circ} 08^{\prime} \mathrm{S}, 117^{\circ} 36^{\prime} \mathrm{E}\right)$ (Figure 20). One Antichiropus species has also been found in the south-eastern region of WA on the Nullarbor Plain $\left(31^{\circ} 43^{\prime} \mathrm{S}, 127^{\circ} 13^{\prime} \mathrm{E}\right)$ but the genus is not found east of this locality, except for a single species, A. mammillifer Jeekel 2006, found only

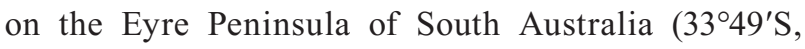
$\left.136^{\circ} 43^{\prime} \mathrm{E}\right)$. 
TABLE 1 Explanation of terms used in description of Antichiropus gonopod structures.

\begin{tabular}{|c|c|c|c|}
\hline Structure & Abbreviation & Explanation & Remarks \\
\hline Coxa & $\mathrm{C}$ & Section of gonopod attached to body. & \\
\hline Prefemur & $\mathrm{PF}$ & $\begin{array}{l}\text { Section between the coxa and the upright femorite } \\
\text { with many setae; at the base of the femorite and often } \\
\text { demarcated from the femorite by a line or fissure. }\end{array}$ & $=$ femur $($ Attems 1911) \\
\hline Femorite & $\mathrm{F}$ & $\begin{array}{l}\text { Long upright 'stalk' of the telopodite } \\
(=\text { solenomere+femorite+prefemur })\end{array}$ & $=$ tibia $($ Attems 1911) \\
\hline Solenomere & $\mathrm{S}$ & $\begin{array}{l}\text { Curved apical structure of the gonopod, carrying the } \\
\text { sperm canal which opens at its tip }\end{array}$ & \\
\hline Main femoral process & MFP & $\begin{array}{l}\text { The process found in all species, arising on the lateral surface } \\
\text { of the femorite, just before its apex }\end{array}$ & $=\mathrm{c}$ process $($ Attems $)$ \\
\hline Other femoral processes & $\mathrm{fp} 1, \mathrm{fp} 2$ etc & $\begin{array}{l}\text { Often absent but additional processes near the apex } \\
\text { of the femorite }\end{array}$ & $\begin{array}{l}=\mathrm{b} \text { process (Attems) and } \\
\text { tibiotarsus (Shear 1992) }\end{array}$ \\
\hline Prolongation of femorite & prof & $\begin{array}{l}\text { prolongation of femorite after it leads into the } \\
\text { solenomere (Shear 1992) }\end{array}$ & $=\mathrm{a}$ process $($ Attems $)$ \\
\hline Solenomere process & $\mathrm{sp} 1$ & $\begin{array}{l}\text { the process (spine or lobe) on the solenomere } \\
\text { closest to its tip }\end{array}$ & $=\mathrm{d}$ process $($ Attems $)$ \\
\hline Solenomere process & $\mathrm{sp} 2, \mathrm{sp} 3 \mathrm{etc}$ & $\begin{array}{l}\text { other processes found on the solenomere and numbered } \\
\text { sequentially from the tip to the solenomere base }\end{array}$ & $=1$ process $($ Attems $)$ \\
\hline
\end{tabular}

Although the genus Antichiropus is widespread and speciose in the region south of the Kimberley, just nine species have been described (Attems 1911; Jeekel 1982; Shear 1992). In this paper, we redefine the genus and redescribe the existing species, designating lectotypes for seven of those species in accordance with Article 74 of the International Code of Zoological Nomenclature, $4^{\text {th }}$ edition (1999). We also include images of various morphological features which occur in Antichiropus species to standardise their descriptions within the genus. Some of these features cannot be discussed in this paper as many specimens of described species are rare, old, damaged or discoloured and cannot be dissected. Terms that are standardised here will be used in a forthcoming paper on Antichiropus species of the Great Western Woodlands area of WA (C. Car and M. Harvey, unpublished data).

\section{MATERIAL AND METHODS}

The material examined for this study is lodged in the Australian National Insect Collection, Canberra (ANIC), California Academy of Sciences, San Francisco (CAS), Naturhistorisches Museum Wien, Vienna (NHMW), South Australian Museum, Adelaide (SAM), Western Australian Museum, Perth (WAM), Museum für Naturkunde, Berlin (ZMB) and the Zoologisches Museum, Hamburg (ZMH).

All gonopods from specimens lodged in the NHMW were originally mounted on slides by Attems with 'gelatin glyzein' but were removed from the slides by NHMW staff by dissolving the mounting medium with warm water. Specimens were subsequently stored in $75 \%$ ethanol. Some of the gonopods showed some degree of flattening and other damage after being removed from the slides. All other material was preserved and examined in $75 \%$ ethanol.

Specimens were examined with Leica MZ6 and MZ16A stereo microscopes and the images were generated with a Leica MZ16A automontage imaging system using Leica Application Suite Version 3.7.0 software. Where possible, images of whole specimens were captured first and then various body parts were removed for imaging. A set of images of each gonopod from four orientations (posterior, anterior, medial and lateral) was captured. In most cases, images of lectotype material were generated: where the type material was slightly damaged or gonopods were obscured on the type specimen, other suitable specimens were used for imaging.

Throughout the text and in figure captions, WA is used for Western Australia. 


\section{GONOPOD MORPHOLOGY}

The paradoxosomatid gonopod is the single most reliable morphological feature used to separate species but there is no standardised terminology for describing polydesmidan gonopods (Jorgensen and Sierwald 2010; Rowe and Sierwald 2006). Here, we have largely followed Car and Harvey (2013) in labelling the main structures of the gonopod. Attems (1911) adopted a system of labelling gonopodal processes with letters when describing the genus Antichiropus. These processes vary in number among species; there may be one, two or three processes 'of indeterminate identity' (Shear 1992) arising near the distal end of the Antichiropus femorite and these were labelled ' $a$ ', 'b' and 'c' by Attems. According to Shear, process ' $a$ ' appears to be a prolongation of the femorite, ' $b$ ' is the tibiotarsus as identified by Jeekel (1968) and 'c' is a femoral process. In addition, there may be several other processes present on the solenomere, labelled ' $d$ ' and ' $l$ ' by Attems. The labelling of processes on the gonopod using Attems' notation has been abandoned in this paper. For clarity, sections of the telopodite used in species descriptions have been given standardised abbreviations (Figure 1) and are explained and compared with Attems' notation (Table 1). Thus, the gonopod coxa is labelled $\mathbf{C}$, the prefemur $=\mathbf{P F}$, the femorite $=\mathbf{F}$, the main lateral femoral process $=\mathbf{M F P}$, other femoral processes $=\mathbf{f p} \mathbf{1}, \mathbf{f p} \mathbf{2}$ etc., prolongation of the femorite

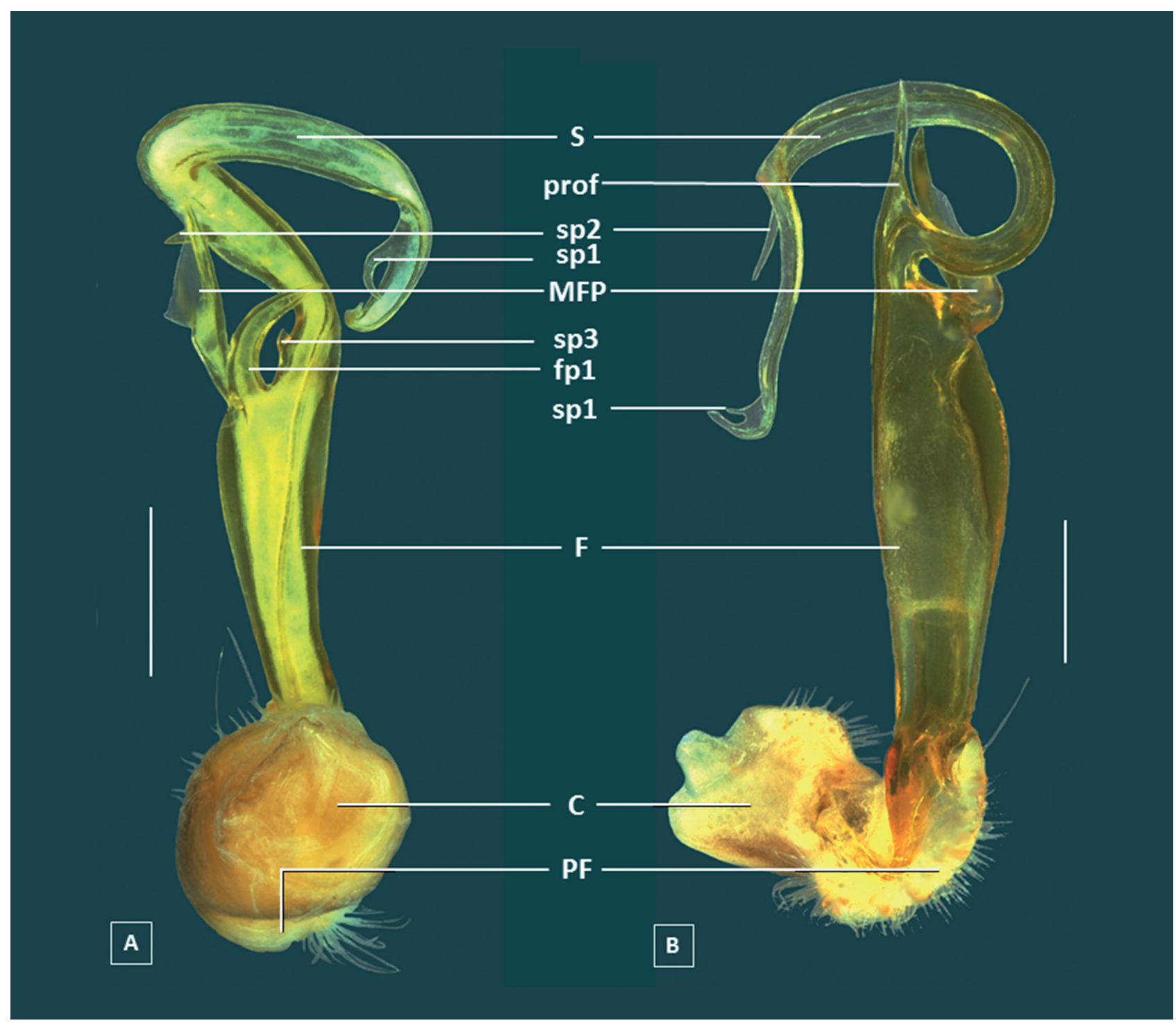

FIGURE 1 Left gonopods of two different Antichiropus species: A, anterior view, Antichiropus sp. nov. from Boorabin, WA. (WAM T71811); B, medial view, Antichiropus sp. nov. from Mt Gibson Station, WA (WAM T42304) showing the different regions referred to in species descriptions. Abbreviations: $C$, coxa; F, femorite; fp1, femoral process; MFP, main femoral process; PF, prefemur; prof, prolongation of femorite; S, solenomere; sp1, 2 and 3, solenomere processes. Scale bars $=0.5 \mathrm{~mm}$. 

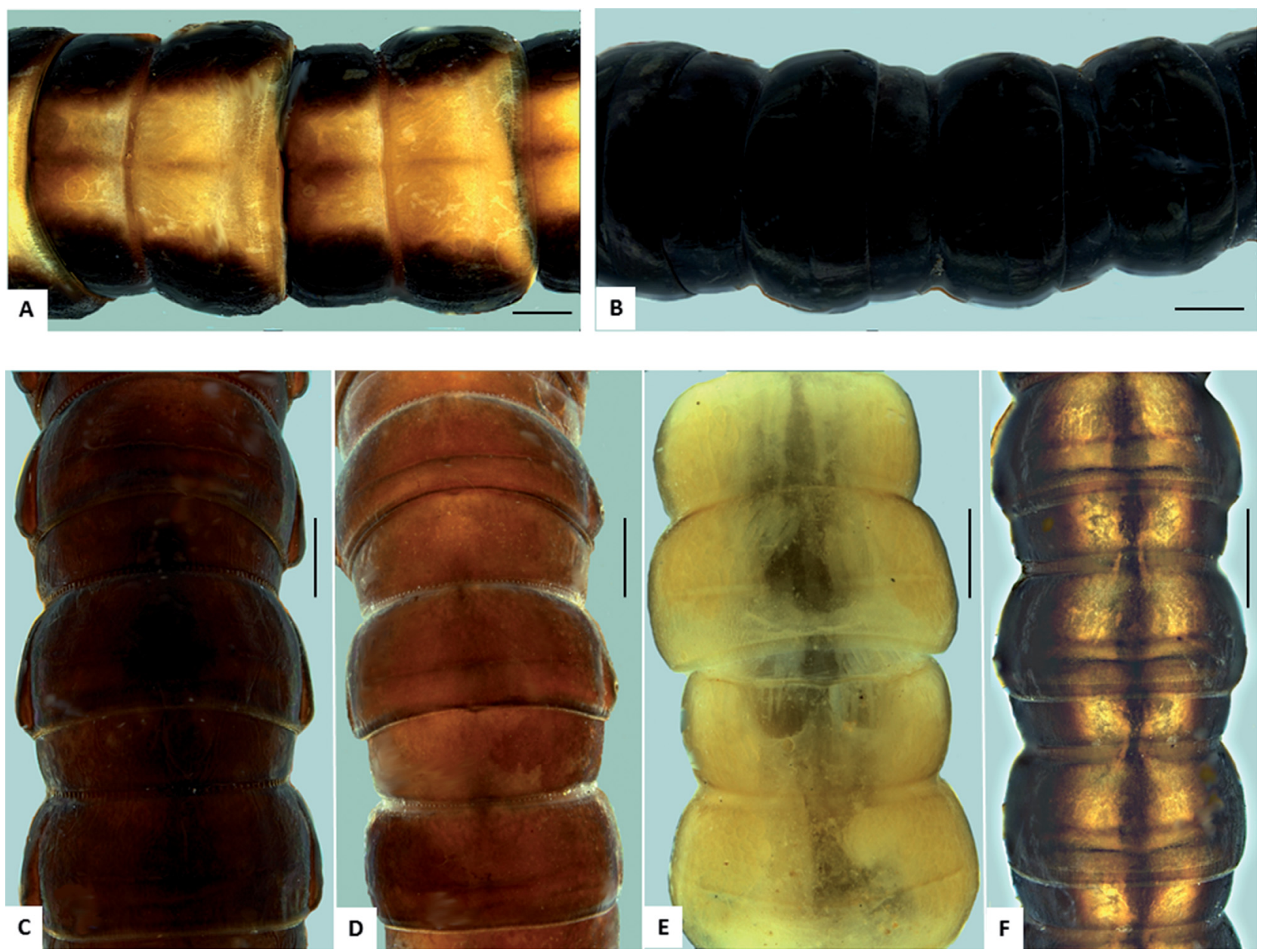

FIGURE 2 Dorsal views of six Antichiropus species showing variation in form and colour: A, Antichiropus sp. nov. from Dunn Rock, WA (WAM T76739) indistinct waist, broad dorsal stripe, no paranota; B, Antichiropus sp. nov. from Disappointment Rock, WA (WAM T115026) distinct waist, almost black, no paranota; C, Antichiropus sp. nov. from Esperance, WA (WAM T71874) distinct beaded waist, dark brown colour, small paranota; D, Antichiropus sp. nov. from Boorabin, WA (WAM T71811) distinct beaded waist, chestnut brown, paranota as slight protuberances; E, Antichiropus sp. nov. from McDermid Rock, WA (WAM T72055) distinct waist, bleached, no paranota; F, Antichiropus sp. nov. from Dundas Rocks, WA (WAM T115034) distinct waist, two pale dorsal stripes, no paranota. Scale bars $=0.5 \mathrm{~mm}$.

$=$ prof, the solenomere $=\mathbf{S}$ and any process on the solenomere $=\mathbf{s p 1}, \mathbf{s p 2}, \mathbf{s p 3}$ etc., numbered sequentially from solenomere tip to base. Processes are numbered for convenience: we do not imply necessarily that those processes with the same numbers across species are homologous.

While it is mainly variations in gonopod structure that are used for species differentiation, other characters can be used, in conjunction with gonopod features, to assist in Antichiropus species characterization. These may include: colour patterns (Figure 2); general body length and width, both of which appear to be relatively uniform among adults of each species, although females are usually slightly broader than males within species; the appearance of the body ring waist (constriction behind the fusion of prozonite and metazonite) (Figure 3); collum length (a) as a proportion of head length (b)
(Figure 4); the shape of the sternal lamella (a flangelike structure on the sternum of the fifth body ring in males) (Figures 5, 6); the presence/absence of sternal cones (Figure 5); and the shape of the midbody anterior spiracles (Figure 7).

We have termed the anterior view of the head as the 'face'. The face may be either narrow, when the cardines and stipites are clearly visible when viewed anteriorly (Figure 8B), or broad, when the cardines are at least partially obscured by the 'cheeks' measured at their widest point (c) (Figure 8A). We have used Mesibov's notation (2013a) in referring to the spacing between antennal sockets (s) which varies from species to species, and is usually compared with the antennal socket diameter (d) (Figures 8A, 8B). 

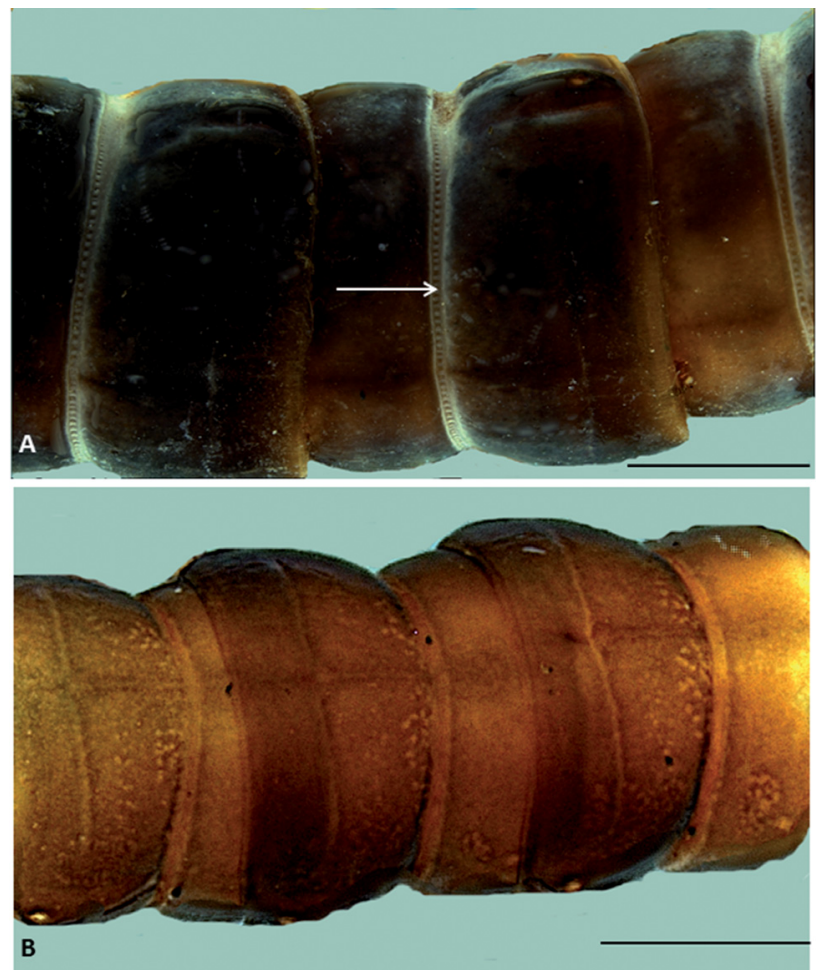

FIGURE 3 Dorsal views of two Antichiropus species: A, Antichiropus sp. nov. from Kwelkan, WA (WAM T74491) showing beaded waist (at arrow); B, Antichiropus sp. nov. from Mt Gibson, WA (WAM T65520) showing smooth waist. Scale bars $=1 \mathrm{~mm}$

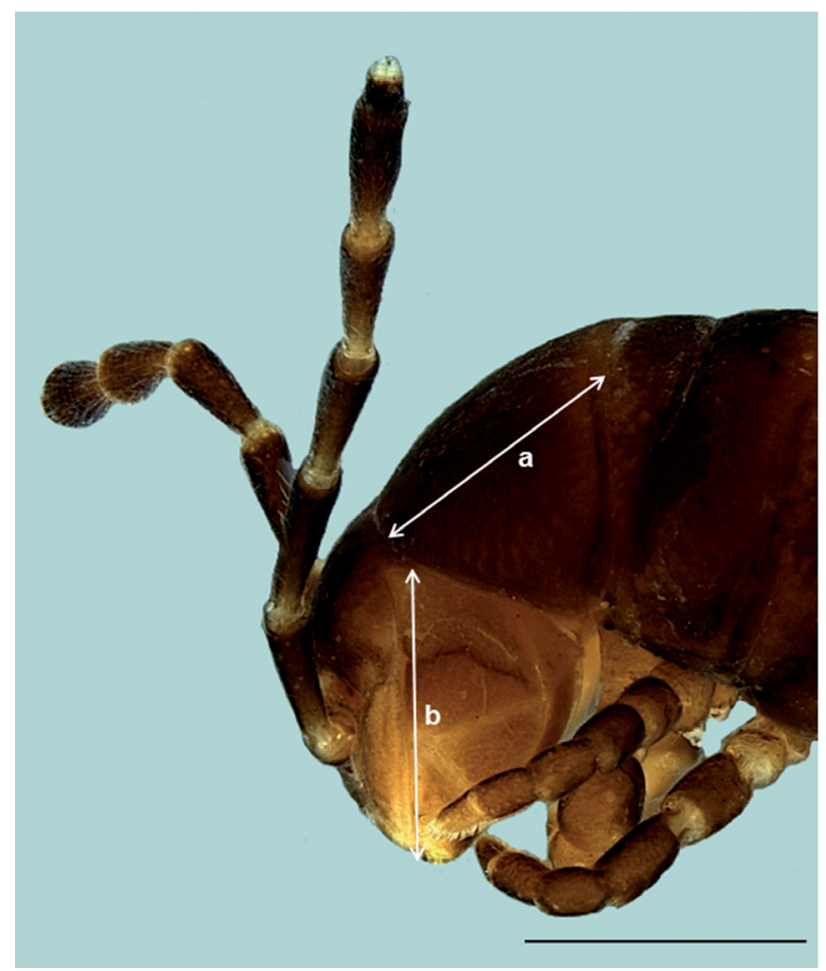

FIGURE 4 Antichiropus humphreysi Shear, 1992, male (WAM T92284), anterior lateral view showing length of collum (a) and length of head (b). Scale bar $=1 \mathrm{~mm}$.
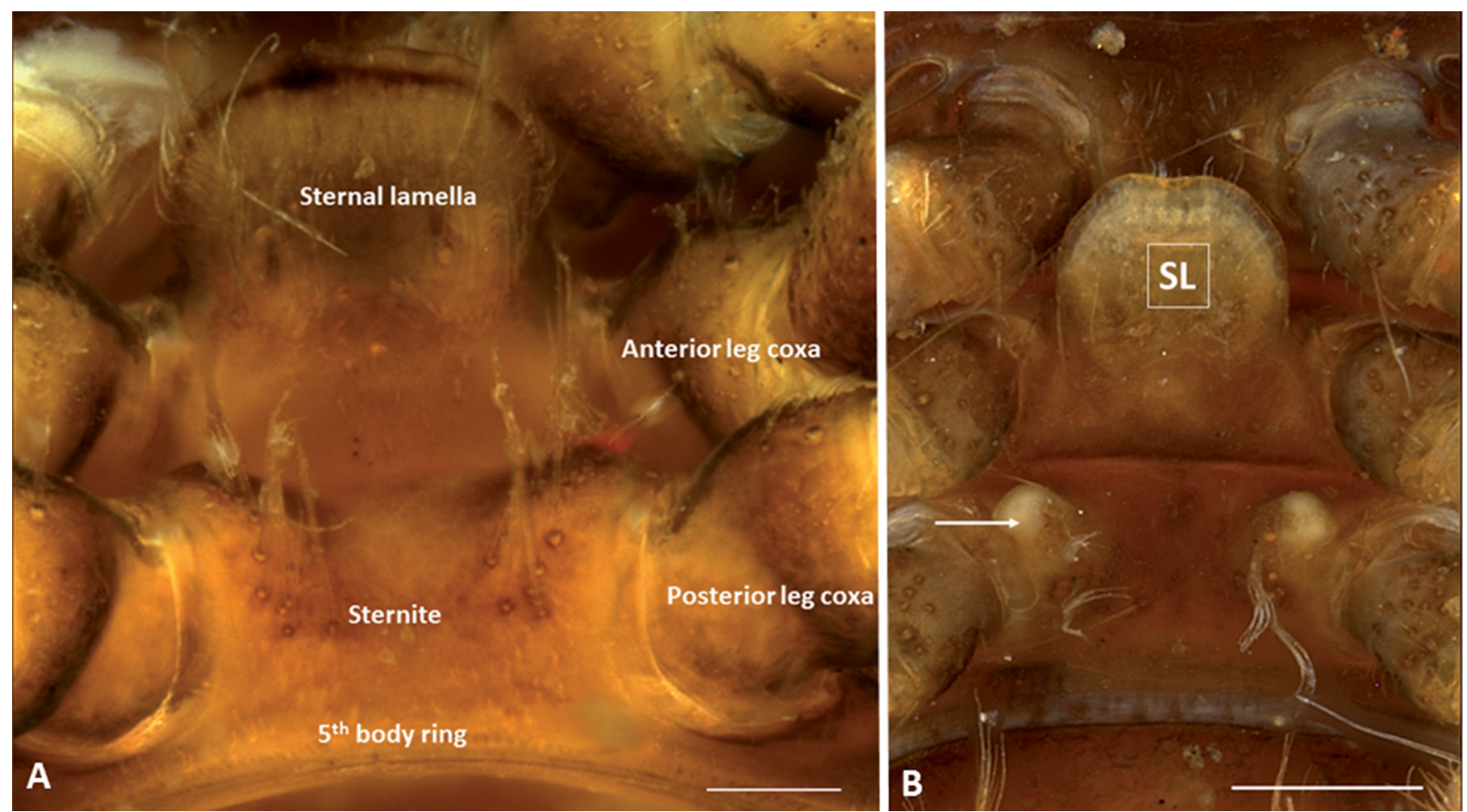

FIGURE 5 Ventral view of 5th body ring, showing sternal lamella (SL): A, Antichiropus whistleri Attems, 1911, male (WAM T53595) without sternal cones; B, Antichiropus mammillifer Jeekel, holotype male (SAM OM1389) with sternal cones/processes (indicated by arrow) Scale bars: $A=0.2 \mathrm{~mm} ; B=0.5 \mathrm{~mm}$. 

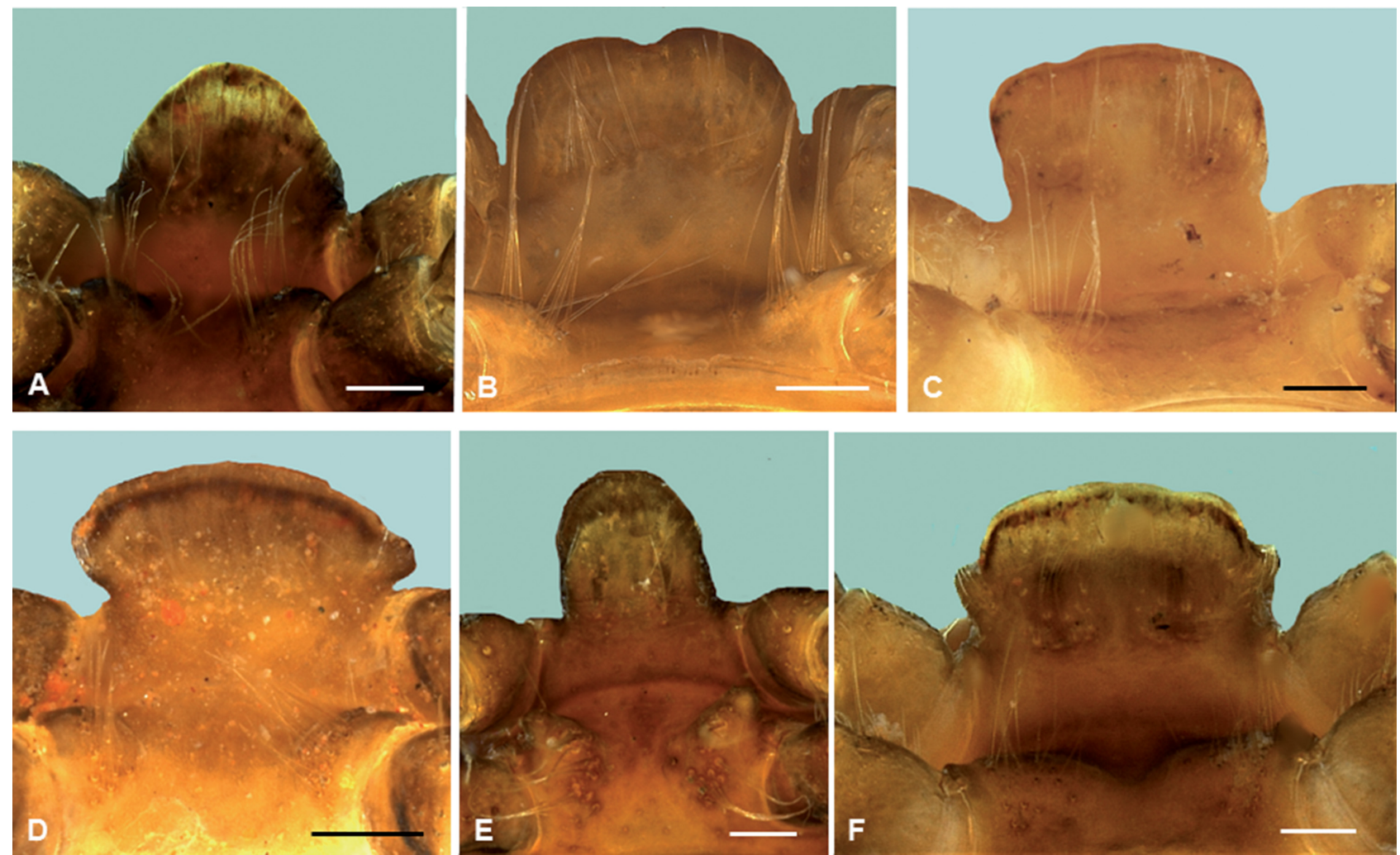

FIGURE 6 Shapes of male sternal lamellae in six Antichiropus species: A, Antichiropus sp. nov. from Marvel Loch, WA (WAM T96078), broad rounded shape; B, Antichiropus sp. nov. from Norseman, WA (WAM T72616), heart shape; C, Antichiropus sp. nov. from Beacon, WA (WAM T42304), square shape; D, Antichiropus sp. nov. from Kambalda, WA (WAM T112935), mushroom shape; E, Antichiropus sp. nov. from Mt Dean, WA (WAM T112930), narrow rounded shape; F, Antichiropus sp. nov. from Koolyanobbing, WA (WAM T99084), helmet shape. Scale bars $=0.2 \mathrm{~mm}$.

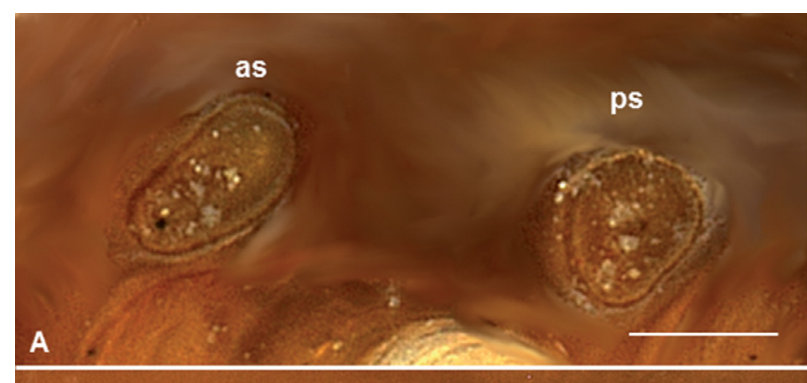

as

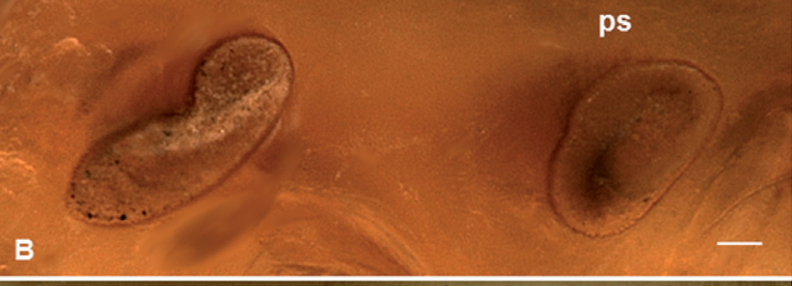

as

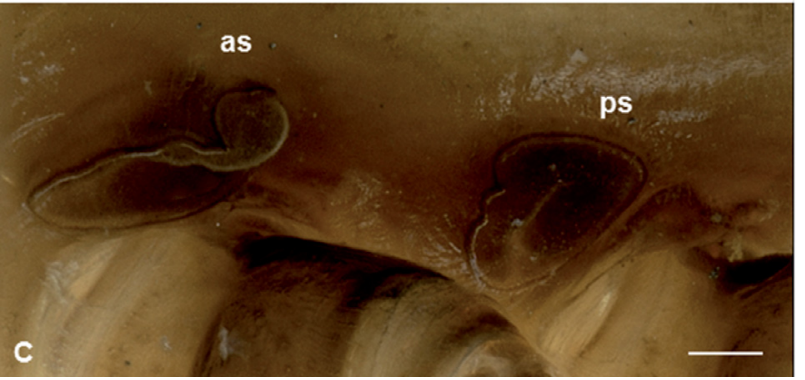

FIGURE 7 Anterior spiracle shapes in Antichiropus species: A, Antichiropus sp. nov., male from Boorabin, WA (WAM T71811), flat spiracles; B, Antichiropus sp. nov., male from Koolyanobbing, WA (WAM T71992) slightly folded spiracles; C, Antichiropus variabilis Attems, 1911, male (WAM T77962), prominent folded spiracles. Abbreviations: as, anterior spiracle; ps, posterior spiracle. Scale bars $=0.1 \mathrm{~mm}$. 

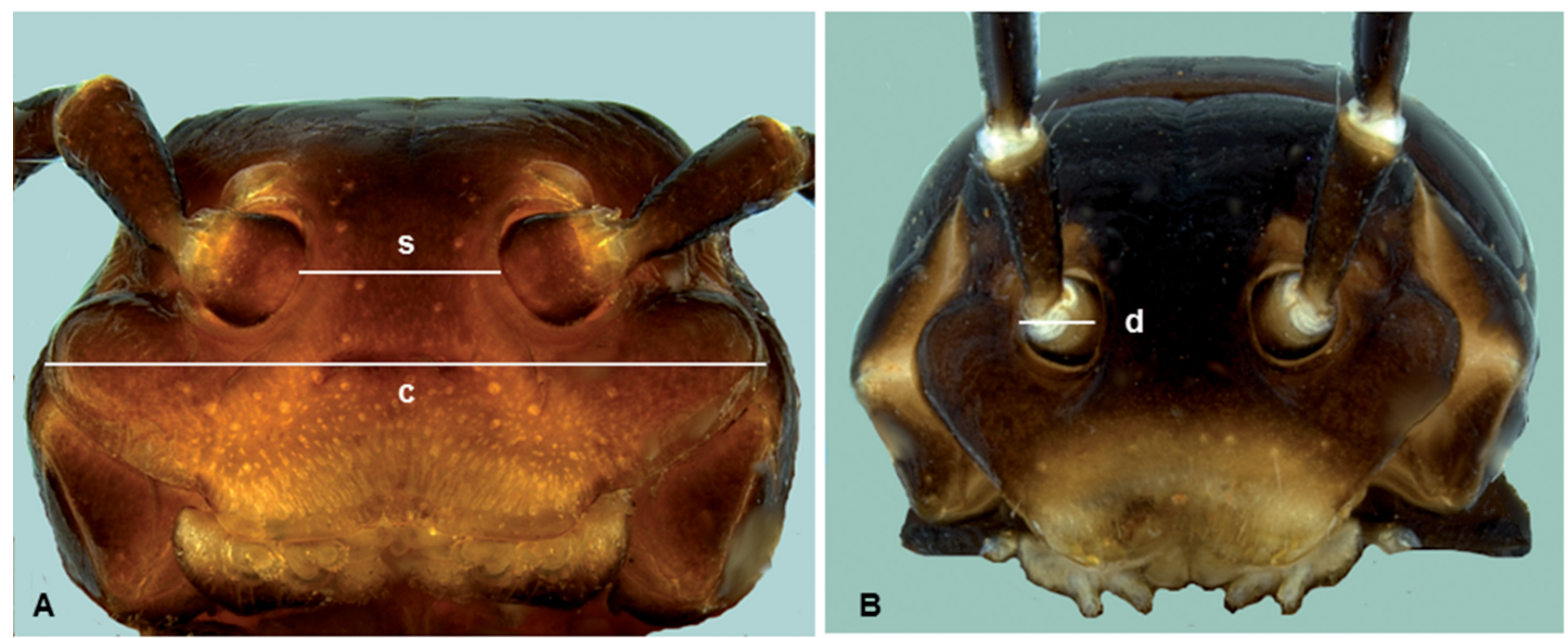

FIGURE 8 Faces of two Antichiropus species: A, Antichiropus sp. nov. from Norseman, WA (WAM T72616), showing a broad face; B, Antichiropus sp. nov. from Credo Station, WA (WAM T119044), showing a narrow face. Abbreviations: c, widest part of face; s, distance between antennal bases; d, width of antennal base.

\section{TAXONOMY}

\section{Order Polydesmida Pocock, 1887}

\section{Suborder Strongylosomatidea Brölemann, 1916}

\section{Family Paradoxosomatidae Daday, 1889}

Tribe Antichiropodini Brölemann, 1916

\section{Genus Antichiropus Attems, 1911}

Antichiropus Attems 1911: 168.

\section{TYPE SPECIES}

Antichiropus variabilis Attems, 1911, by subsequent designation of Brölemann (1916).

\section{DIAGNOSIS}

The genus Antichiropus is most similar to the genus Notodesmus Chamberlin, 1920 and to several other undescribed genera that occur in Queensland and Victoria in Australia: the gonopod of each comprises a long femorite and a long free solenomere, as do most members of the Antichiropodini (Brölemann 1916; Jeekel 1968) but additionally, each has a solenomere that is long enough to curl into a semicircle. Each may have one or more processes on the femorite and solenomere, but Antichiropus may be distinguished by a unique combination of four gonopodal features. Firstly, the solenomere is remarkably long in Antichiropus: it is generally as long as the femorite and coiled into a complete circle, or more, in nearly all species. Secondly, the solenomere is characterised by the presence of one or more processes or 'lappets' on its length (Jeekel 1965). All Antichiropus species carry one process, namely, the solenomere process 1 (spl) in the apical third of the solenomere and on its inner surface (probably Attems' $d$ '). This last feature alone distinguishes Antichiropus from the superficially similar genus Notodesmus which lacks any process at the solenomere tip (Chamberlin 1920; Jeekel 1979). Thirdly, although there may be between one and three processes present on the femorite of the Antichiropus gonopod, all species carry a large pointed prominent process arising on the lateral surface of the femorite, close to its tip, but not at its apex (Attems' 'c' process) called here the main femoral process (MFP). Finally, the sperm canal bends at a right angle at the tip of the femorite before continuing on the solenomere; this characteristic can be used in conjunction with the other features as diagnostic of the genus (e.g. Figure 1).

\section{DESCRIPTION}

Broadly, the general body features of the genus include: 20 body segments, each smooth and unsculptured, generally with distinct waist between prozonite and metazonite; transverse cross impressions on sternites deeper than longitudinal; paranota absent, poorly developed or small; normal pore formula; legs and antennae with no remarkable features; and legs of moderate length, approximately equal to the length of 1 to 2 mid-body rings. The genus is only definitively characterised by features of the gonopod: coxa generally 
broad and robust; prefemur sub-globose, with distinct line where prefemur joins femorite; femorite long, with prominent process present apically on lateral surface; solenomere long, usually curled into a circle and always with a process between midpoint and tip, usually closer to tip.

\section{REMARKS}

Attems (1911) commented that Antichiropus was characterised by the nature of the solenomere on the male gonopod, although it appears that he did not describe the distinguishing characteristic. The entire gonopod, including the solenomere, remains the single most important structure in differentiating between genera and separating species. Body characters within Antichiropus vary from species to species: although there are some that are consistent within a species, they are not necessarily particular to any one species and occur randomly in various species within the genus.

\section{Antichiropus variabilis Attems, 1911}

$$
\text { Figures 7C, 9, 10, } 21
$$

Antichiropus variabilis ingens Attems, 1911: 171, Figures 26, 27, 28.

Antichiropus variabilis Attems: Brölemann, 1916: 539 (designated as type of Antichiropus).

\section{MATERIAL EXAMINED}

\section{Lectotype (new designation)}

Australia: Western Australia: के with gonopods attached: Gooseberry Hill [31 $57^{\prime} \mathrm{S}, 116^{\circ} 03^{\prime} \mathrm{E}$ ], Hamburger südwest-australischen Forschungsreise, Station 152, 31 May 1905, W. Michaelsen and R. Hartmeyer (NHMW 3440).

\section{Paralectotypes}

Australia: Western Australia: All specimens collected by W. Michaelsen and R. Hartmeyer during the Hamburger südwest-australischen Forschungsreise: 3 o (gonopods attached), 2 juveniles, collected with lectotype (ZMH); 1 $\widehat{\sigma}$ (without gonopods), $1 \hat{\sigma}$ (gonopods attached), York [31 $\left.53^{\circ} \mathrm{S}, 116^{\circ} 46^{\prime} \mathrm{E}\right]$, Station 155, 11 August 1905 (NHMW 3441); 2 วิ, same details (WAM T266, original number 13/7128A, WAM T267, original number 13/7128B); 1 \&, 1 juvenile, Guildford [31 $\left.54^{\prime} \mathrm{S}, 115^{\circ} 58^{\prime} \mathrm{E}\right]$, Station 103, 28 August 1905 (ZMB 5151a); $1 \hat{\jmath}$ (gonopods attached), 2 juveniles, Cannington $\left[32^{\circ} 53^{\prime} \mathrm{S}, 116^{\circ} 46^{\prime} \mathrm{E}\right]$ Station 123, 28 June

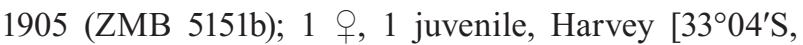
$115^{\circ} 53^{\prime}$ E], Station 136, 27 July 1905 (ZMB 5151c); 1

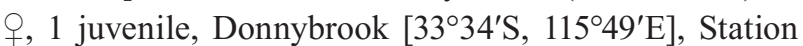

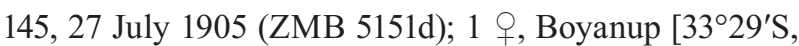
$\left.115^{\circ} 43^{\prime} \mathrm{E}\right]$, Station 146, 1-3 August 1905 (ZMB 5151e); 2 万o (gonopods attached), 2 + , Pickering Brook $\left[32^{\circ} 02^{\prime} \mathrm{S}\right.$, $\left.116^{\circ} 07^{\prime} \mathrm{E}\right]$, Station 154, 22 July 1905 (ZMB 5151f); 1 $\widehat{\sigma}$ (gonopods attached) 1 +, 2 juvenile $\widehat{o}$, Mundaring

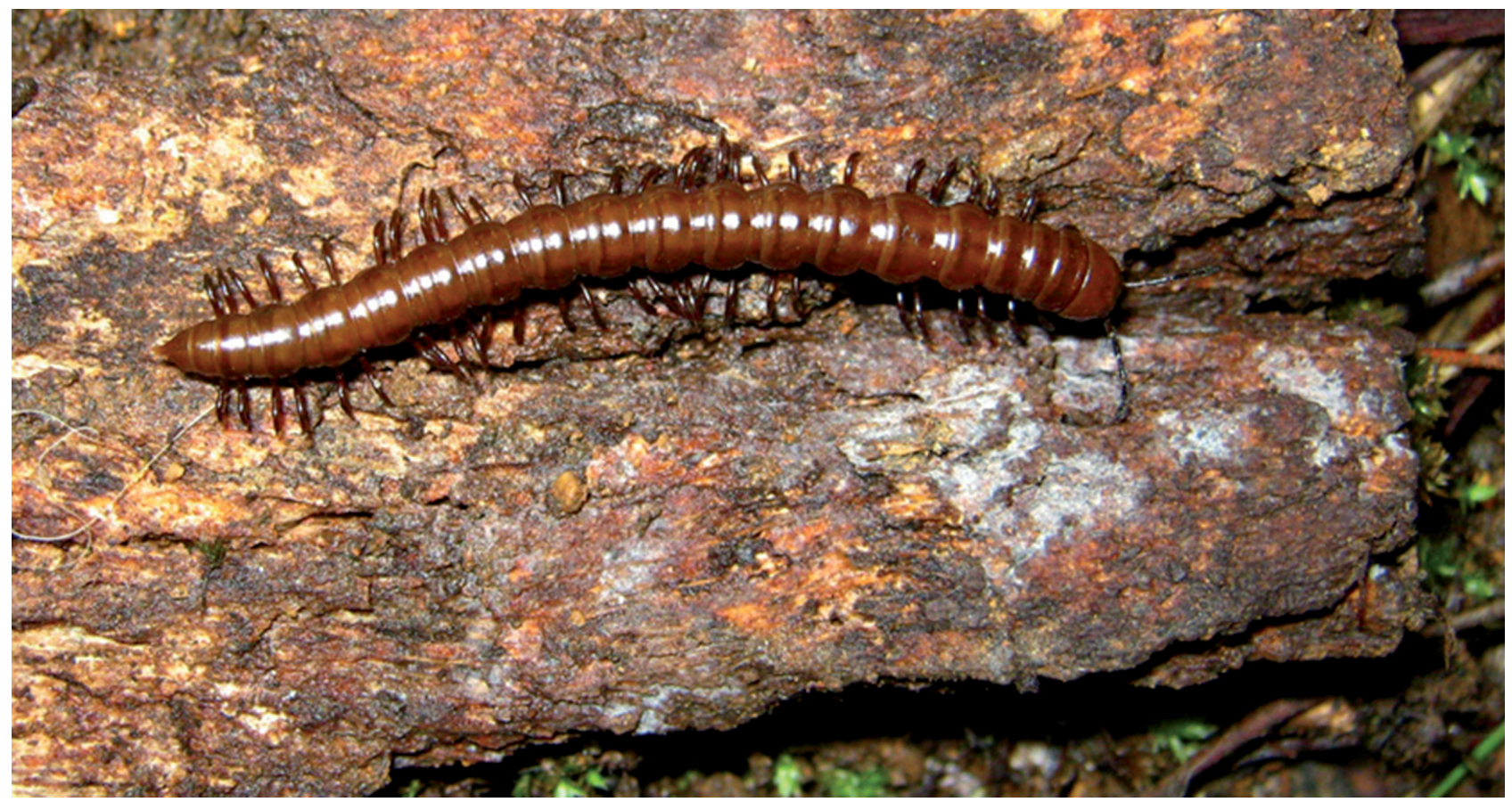

FIGURE 9 Antichiropus variabilis Attems, 1911, dorsal view of living male approximately 45 mm long, Darling Ranges, Perth, WA, 2012. 

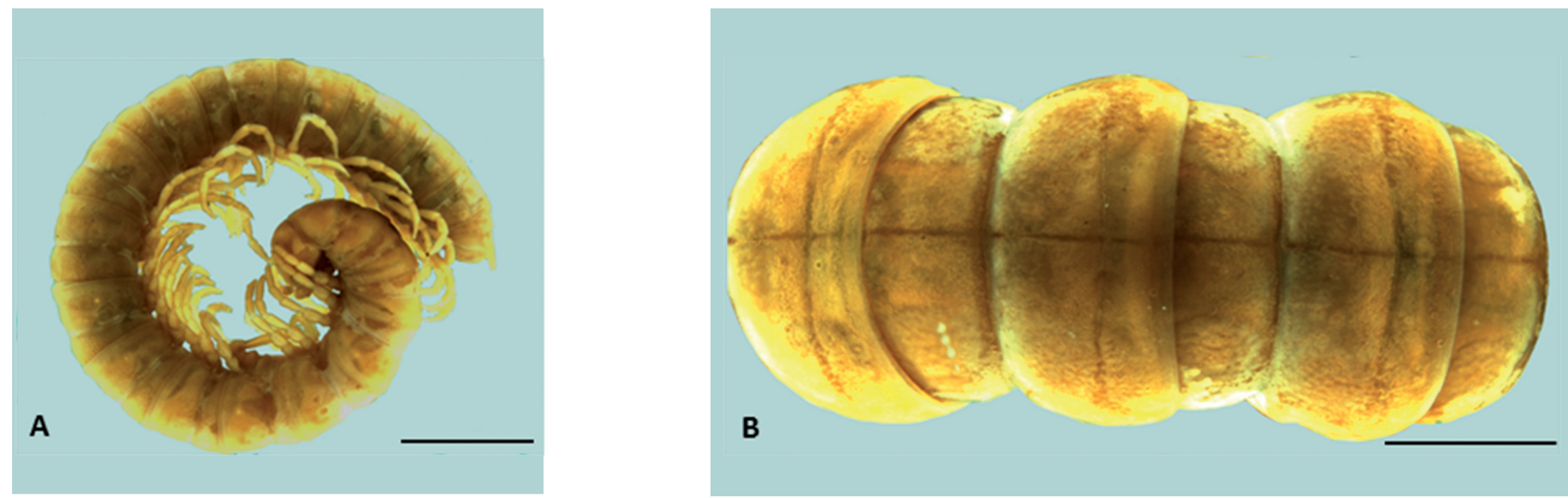

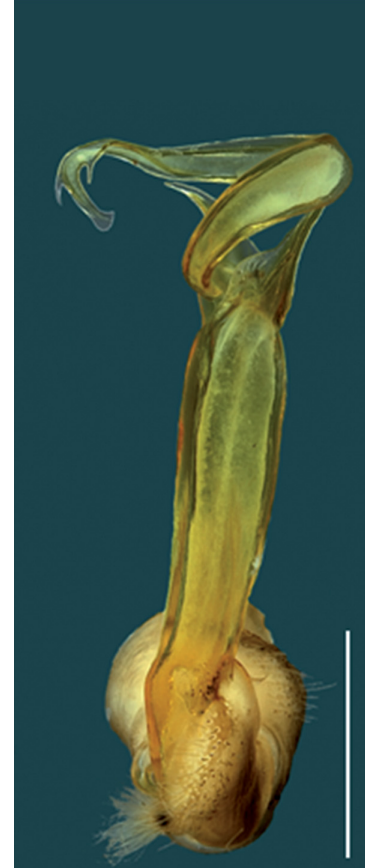

C
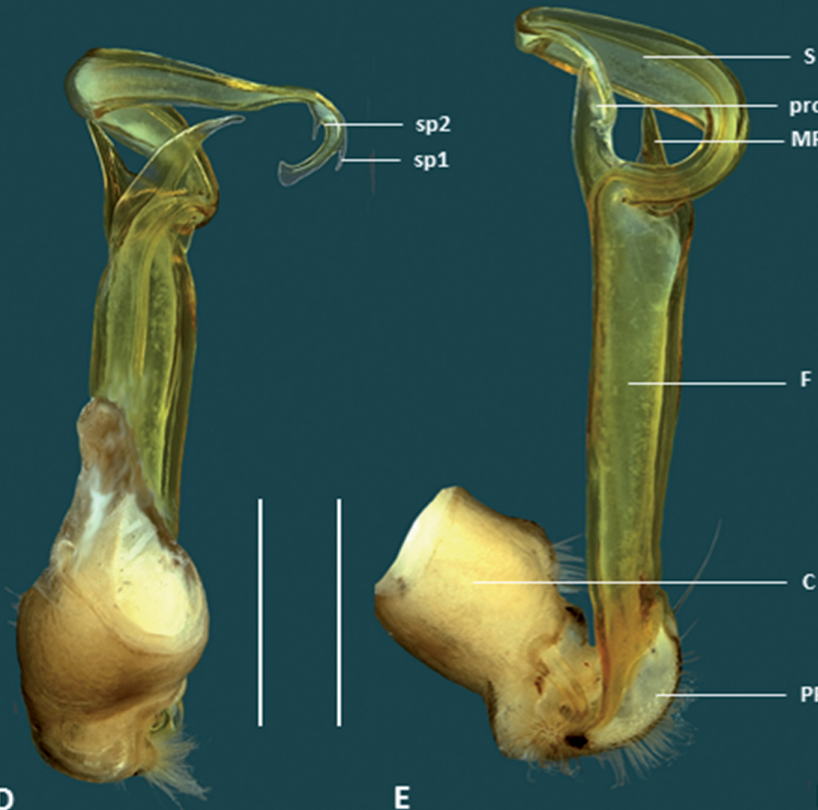

E

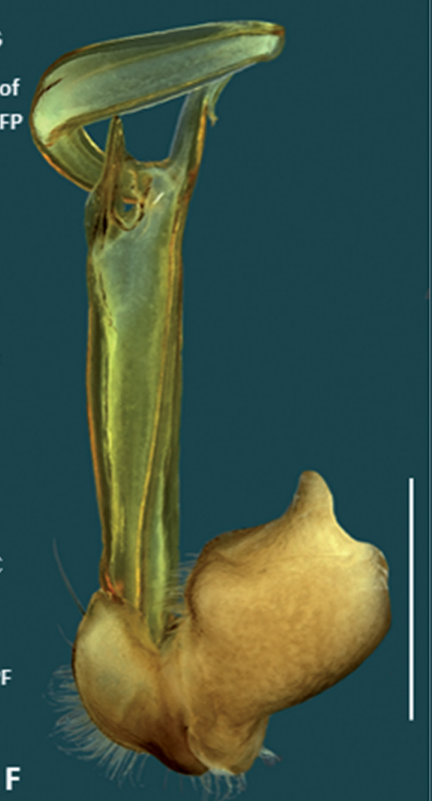

FIGURE 10 Antichiropus variabilis Attems: A-B, lectotype male (NHMW 3440), habitus: A, lateral view; $\mathrm{B}$, dorsal view; C-F, male (WAM T119595), left gonopod: C, posterior view; $D$, anterior view; E, medial view; F, lateral view. Abbreviations: C, coxa; F, femur; MFP, main femoral process; PF, prefemur; prof, prolongation of femur; $\mathrm{S}$, solenomere; sp1 and sp2, solenomere processes 1 and 2. Scale bars: $A=5 \mathrm{~mm} ; B=2 \mathrm{~mm} ; C-F=1 \mathrm{~mm}$.

Weir [31 $57^{\prime} \mathrm{S}, 116^{\circ} 09^{\prime} \mathrm{E}$ ], Station 101, 9 August 1905 $(\mathrm{ZMH}) ; 2$ ก (gonopods attached), East Fremantle [32 $\left.02^{\prime} \mathrm{S}, 115^{\circ} 46^{\prime} \mathrm{E}\right]$, Station 116, 19 July 1905 (ZMH); $1 \hat{\delta}$ (gonopods attached) 1 \&, 1 juvenile, Bridgetown [335' S, $116^{\circ} 08^{\prime} \mathrm{E}$ ], Station 144, 30-31 July 1905 (ZMH); 1 ते (gonopods attached) Collie $\left[33^{\circ} 22^{\prime} \mathrm{S}\right.$, $\left.116^{\circ} 09^{\prime} \mathrm{E}\right]$, Station 137, 26 August 1905 (ZMH); $2 \curvearrowright$ (gonopods attached), 2 +, 1 juvenile,+ 10 juveniles, broken pieces, Wooroloo [ $\left.31^{\circ} 48^{\prime} \mathrm{S}, 116^{\circ} 19^{\prime} \mathrm{E}\right]$, Station 98,

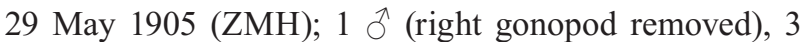
$\widehat{\delta}$ (gonopods attached), 1 +, 7 juvenile $\hat{\partial}, 3$ juvenile + , 1 juvenile, Lion Mill [ $\left.31^{\circ} 52^{\prime} \mathrm{S}, 116^{\circ} 12^{\prime} \mathrm{E}\right]$, Station 99, 22 May 1905 (ZMH); also 1 juvenile, Brancaster, Upper

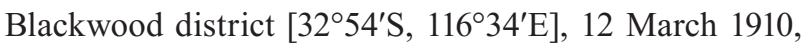
J.M. Whistler (ZMB 5151g);

\section{Other material}

For all other specimens of $A$. variabilis examined, see Appendix 1. 


\section{DIAGNOSIS}

This species is distinguished by size and colour and its gonopod structure. Antichiropus variabilis and $A$. mammillifer are by far the largest known Antichiropus species but are widely separated in distribution (Figures 21, 25). A. variabilis is usually noticeably lighter coloured than other species (Figures 9, 10). The gonopod has a characteristic long tapering solenomere held at right angles to the femorite (Figure 10C, D) and often curling back on itself when viewed medially. There are two small processes close to the rounded tip of the solenomere (Figures 10C, D). The main femoral process is upright, relatively short, tapering to a slender point, while the prolongation of the femorite is a large broadbased curved process ending in a sharp point (Figure 10E, F): the two processes appear to curve away from each other and the gonopod midline when viewed anteriorly (Figure 10D).

\section{DESCRIPTION}

\section{Male (lectotype)}

Body approximately $35 \mathrm{~mm}$ long; midbody ring approximately $3.5 \mathrm{~mm}$ wide with a distinct waist between prozonite and metazonite of similar width. Colour (of lectotype $\lesssim$ ) bleached in alcohol (Figure $10 \mathrm{~A}, \mathrm{~B})$ but a uniform light chestnut brown when alive (Figure 9); legs with coloration similar to that of body. Paranota absent. Sternites, other than those of the 5th body ring, with no noticeable features; sternite of 5th body ring without obvious processes/tubercles; sternal lamella broad, with distal edge wider than base. Anterior spiracles at midbody prominent, folded (Figure 7C). Head smooth, without noticeable sculpturing. Frons smooth, with some setae. Face broad, the cardines partially obscured by the 'cheeks' when animal is viewed 'face on'; distance between antennal sockets (s) approximately $1.5 \mathrm{x}$ width of antennal socket (d) (Figure 8). Antennae of moderate length, extending approximately to first body ring behind collum, and approximately uniform in width, the 6th antennomere of similar size to proximal ones, antennomeres relatively robust. Collum $0.8 \mathrm{x}$ as long as head (in lateral view) (Figure 10A). Paralectotype $\widehat{\jmath}$ (WAM T266): Gonopods of medium length, extending to posterior edge of 5th body ring; coxa (C) stockier, shorter than femorite; prefemur (PF) considerably shorter than femorite, ovoid; femorite (F) contributing to approximately two thirds or more of the total vertical height of the acropodite, and of similar thickness along its length; main femoral process (MFP) relatively short, thick at base, becoming more slender towards pointed tip, relatively slender when viewed laterally, but of similar shape to the prolongation of femorite (prof) when viewed anteriorly; prof large, broad-based, curved, sharply pointed; solenomere (S) moderately long, noticeably much more slender in apical third, held at right angles to femorite and curling back on itself; solenomere tip rounded and flattened; solenomere processes (sp1 and sp2) near tip of solenomere, small, pointed, upright, on opposite edges (Figures 10C-F).

\section{Female}

Body colour light chestnut brown, similar to $\widehat{\sigma}$ in overall appearance, but generally slightly broader when viewed dorsally (approximately $4 \mathrm{~mm}$ wide) and sometimes shorter.

\section{REMARKS}

Originally, $A$. variabilis was divided into two subspecies by Attems. Chamberlin (1920) suppressed the subspecies name $A$. variabilis ingens as a synonym of $A$. variabilis sens. str.

The gonopod of $A$. variabilis has been shown to vary in details of its structure among isolated geographic populations (Wojcieszek and Simmons 2012) but is still easily separated from those of other species. Antichiropus variabilis is one of the very few widespread species of the genus, with a distribution stretching from New Norcia (34 $\left.54^{\prime} 50^{\prime \prime} \mathrm{S}, 116^{\circ} 18^{\prime} 54^{\prime \prime} \mathrm{E}\right)$ in the north (WAM T127011) to Shannon State Forest $\left(34^{\circ} 43^{\prime} 10^{\prime \prime} \mathrm{S}, 116^{\circ} 31^{\prime} 02^{\prime \prime} \mathrm{E}\right)$ in the south (WAM T54836) (Figure 21). One study examined how the processes of the gonopod interact with the female genitalia in copulo (Wojcieszek et al. 2012). Wojcieszek et al. (2011) dubbed this species the marri millipede as it is almost always collected in marri (Corymbia calophylla) leaf litter.

\section{Antichiropus fossulifrons Attems, 1911}

Figures 11, 21

Antichiropus fossulifrons Attems, 1911: 176, Figures 37, 38.

\section{MATERIAL EXAMINED}

\section{Lectotype (new designation)}

Australia: Western Australia: के with gonopods attached: Yalgoo [28 $\left.20^{\prime} \mathrm{S}, 116^{\circ} 42^{\prime} \mathrm{E}\right]$, Hamburger südwest-australischen Forschungsreise Station 77, 11 July 1905, W. Michaelsen and R. Hartmeyer (NHMW 3432).

\section{Paralectotypes}

Australia: Western Australia: $1 \curvearrowright$ (gonopods only), 1 + , collected with lectotype (NHMW 3432); 1 ठै (without gonopods), collected with lectotype (ZMB 5156); 1 , 1 juvenile, Eradu [28 $\left.42^{\prime} \mathrm{S}, 115^{\circ} 02^{\prime} \mathrm{E}\right]$, Hamburger südwest-australischen Forschungsreise Station 80, 13 July 1905, W. Michaelsen and R. Hartmeyer (ZMH) (but not conspecific with lectotype - see Remarks). 

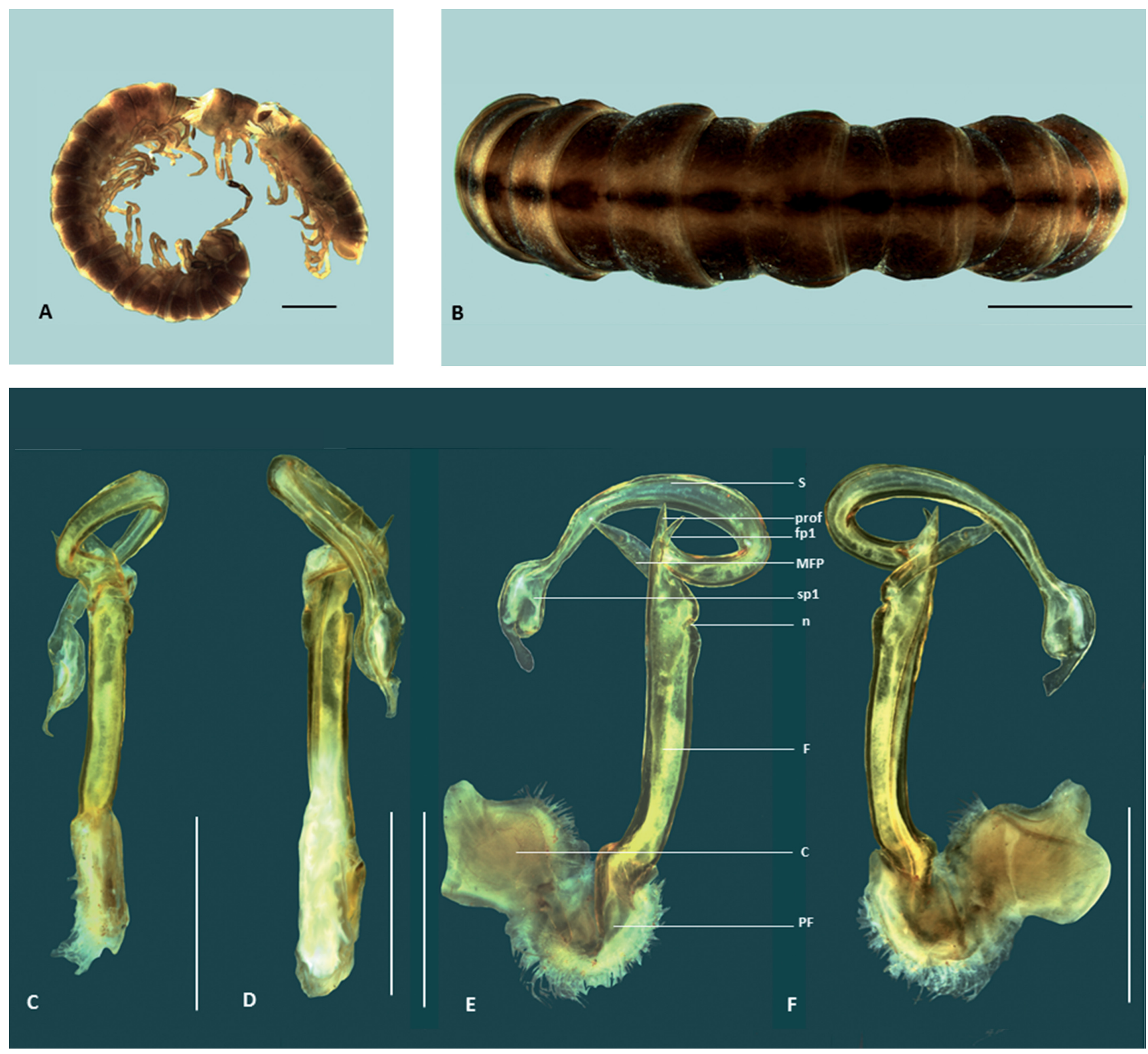

FIGURE 11 Antichiropus fossulifrons Attems: A-B, paralectotype male (ZMB5156) habitus: A, lateral view; B, dorsal view; C-F, lectotype male (NHMW 3432), left gonopod: C, posterior view; D, anterior view; E, medial view; F, lateral view. Abbreviations: C, coxa; F, femur; fp1, femoral process 1; MFP, main femoral process; $n$, notch; PF, prefemur; prof, prolongation of femur; $\mathrm{S}$, solenomere; sp1, solenomere process 1. Scale bars: $A-B=2 \mathrm{~mm}$; $\mathrm{C}-\mathrm{F}=1 \mathrm{~mm}$.

\section{Other material}

There are no known additional specimens.

\section{DIAGNOSIS}

This species of Antichiropus is recognisable by the combination of a notched femorite (Figures 11E, F) and the unique shape of the solenomere tip which is broadly flattened and carries a lobe like process (Figure 11E).

\section{DESCRIPTION}

\section{Male (lectotype)}

Body approximately $20 \mathrm{~mm}$ long; midbody ring approximately $2 \mathrm{~mm}$ wide with distinct waist between prozonite and metazonite of similar width. Colour (of lectotype $\delta^{\text {) }}$ bleached in alcohol but with distinct broad pale dorsal stripe running length of body (e.g. Figure 2F, Figure 11B); legs with coloration similar to that of body. Paranota on all but first few body rings present only as slight protuberances. Sternites, other than those of the 5th body ring, with no noticeable features; sternites of 5th body ring without obvious processes/tubercles; sternal lamella broad, helmet shaped (e.g. Figure 6F). Anterior spiracles at midbody flat (e.g. Figure 7A). Head smooth, without noticeable sculpturing. Frons smooth, with some setae. Face 
narrow, the cardines and stipites clearly visible when the animal is viewed 'face on'; distance between antennal sockets (s) approximately $1.5 \mathrm{x}$ width of antennal socket (d) (Figure 8). Antennae of moderate length, extending approximately to first body ring behind collum, and approximately uniform in width, the 6th antennomere only slightly wider than proximal ones, antennomeres relatively robust (Figures 11A, B). Collum $1 \mathrm{x}$ as long as head (lateral view). Gonopod (removed from original slide and hence compressed antero-posteriorly) of medium length, extending to posterior edge of 5th body ring; coxa (C) stouter, shorter than femorite, with noticeable ridge on anterior surface; prefemur (PF) considerably shorter than femorite, ovoid; femorite (F) contributing to approximately two thirds or more of vertical acropodite height, upright, and of similar thickness along length, with distinctive notch (n) visible in apical third; main femoral process (MFP) long (as long as one quarter or more of solenomere length), slender, pointed, spear or flame shaped; second femoral process (fp1) present, arising close to solenomere base, pointed, banana shaped; prolongation of femorite apex (prof) present, sharply pointed; solenomere (S) long enough to form more than one loop or circle, generally as thick as femorite, but of variable thickness; solenomere tip with single broadly flattened end with serrations; solenomere process (sp1) near solenomere tip, prominent, lobe-like; not pointed (Figures 11C-F).

\section{Female}

Bleached in alcohol but a broad, pale dorsal stripe discernible; similar in general appearance, size and dorsal width to $\hat{\jmath}$.

\section{DISTRIBUTION}

This species is known only from Yalgoo (Figure 21).

\section{REMARKS}

The NHMW collection consists of 1 o, 1 + and 1 set of unattached gonopods from Yalgoo. It is likely that the separate gonopods belong to the male paralectotype housed in the $\mathrm{ZMB}$, since the paralectotype was collected with the lectotype and has since had its gonopods dissected out and removed from the ZMB collection. The Eradu specimens in the $\mathrm{ZMH}$ are clearly of a different species from A. fossulifrons. We collected Antichiropus specimens at Eradu but did not find $A$. fossulifrons but found a previously undescribed species. It appears that this new species is similar in colour to A. fossulifrons in that both have broad, pale, longitudinal dorsal stripes on their bodies. There are, however, a number of similarly marked species from Geraldton on the coast to Yalgoo in the east, so it seems likely that Attems (1911) identified the Yalgoo and
Eradu specimens as the same species on the basis of colour, since he did not have males from both localities. Attems could not have been aware of the diversity of Antichiropus species in the region, nor of the limited distributions of most species: one could speculate that he believed the two localities were close enough together to share one species, when they are actually $170 \mathrm{~km}$ apart.

As the type series of $A$. fossulifrons consists of two different species, we have selected a lectotype male from Yalgoo to stabilise its taxonomy as demanded by Article 74 of the International Code of Zoological Nomenclature (1999).

\section{Antichiropus humphreysi Shear, 1992}

Figures 4, 12, 24

Antichiropus humphreysi Shear, 1992: 782, Figure 2.

\section{MATERIAL EXAMINED}

\section{Holotype}

Australia: Western Australia: $\hat{\jmath}$, Cave C-225, near Exmouth, Cape Range, North West Cape, 21 ${ }^{\circ} 57^{\prime} \mathrm{S}$, $114^{\circ} 06^{\prime} \mathrm{E}, 10$ July 1989, R.A. Young (WAM T23663; original number WAM 91/1412).

\section{Paratypes}

Australia: Western Australia: 19 , same data as holotype (WAM T23664, original number WAM 91/1413); 1 d, same data as holotype (WAM T23665, original number WAM 91/1414). Shear's paper also lists a male, same data as holotype but 30 June 1989 (Zoologische Museum Amsterdam) as a paratype which was not examined for this paper.

\section{Other material}

Australia: Western Australia: 1 ก, N-W Cape Peninsula, Cave C-225, near entrance, 21 ${ }^{\circ} 56^{\prime} 31^{\prime \prime} \mathrm{S}$, $114^{\circ} 05^{\prime} 39^{\prime \prime E}, 30$ June 1989, M. East (WAM T24349, original number WAM 92/284); $1 \hat{\jmath}$, Cape Range area, Kubura Well, cave C-27, 21 ${ }^{\circ} 55^{\prime} \mathrm{S}, 114^{\circ} 07^{\prime} \mathrm{E}, 17$ June 1993, R.D. Brooks and W.F. Humphreys (WAM

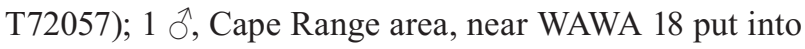
cave, C-498, $21^{\circ} 57^{\prime} \mathrm{S}, 114^{\circ} 06^{\prime} \mathrm{E}, 22$ June 1993, in litter, W.F. Humphreys and R.D. Brooks (WAM T72058); 1 ô, Cape Range area, near cave C-105, 21 ${ }^{\circ} 59^{\prime} \mathrm{S}, 114^{\circ} 07^{\prime} \mathrm{E}, 26$ July 1991, W.F. Humphreys (WAM T72059).

\section{DIAGNOSIS}

Antichiropus humphreysi may be distinguished by the extreme elongation of the solenomere, described by Shear (1992) as twice as long as the remainder of the acropodite (Figures 12C, D). The solenomere also has a characteristic flattened tip and a closely associated flattened solenomere process (Figure 12E). In addition, the prolongation of the femur is broad and bulbous 

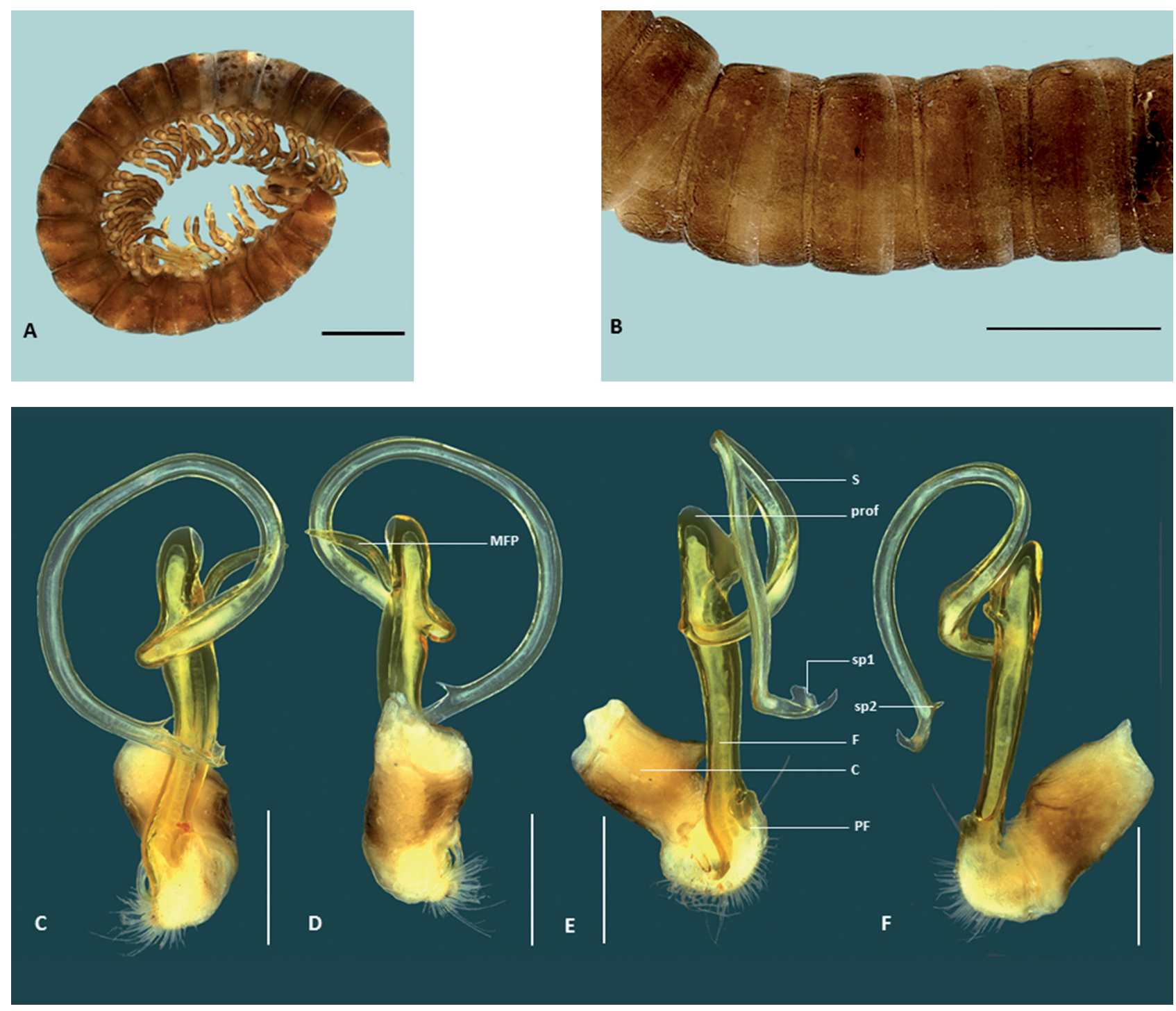

FIGURE 12 Antichiropus humphreysi Shear: paratype male (WAM T23664, original number WAM 91/1412) habitus: A, lateral view; B, dorsal view; C-F, left gonopod: $C$, posterior view; $D$, anterior view; E, medial view; F, lateral view. Abbreviations: C, coxa; F, femur; MFP, main femoral process; PF, prefemur; prof, prolongation of femur; S, solenomere; sp1 and sp2, solenomere processes 1 and 2. Scale bars: $A-B=2 \mathrm{~mm}$; $C-F=0.5 \mathrm{~mm}$.

(Figures 12C-F) and the coxa has a noticeable shelf on the anterior surface (Figure 12E).

\section{DESCRIPTION}

\section{Male and Female}

For a verbal description see Shear (1992). Figures 12C$\mathrm{F}$ are new images of the gonopod originally illustrated in Figure 2 (Shear 1992). Figures 12A-B illustrate the whole specimen and its dorsal view for the first time.

\section{DISTRIBUTION}

This species is restricted to the Cape Range region of WA (Figure 24).

\section{Antichiropus mammillifer Jeekel, 1982}

Figures $5 B, 13,25$

Antichiropus mammillifer Jeekel, 1982: 122, Figure 1.

\section{MATERIAL EXAMINED}

\section{Holotype}

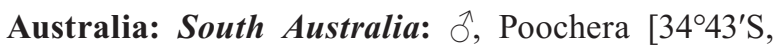
$\left.134^{\circ} 50^{\prime} \mathrm{E}\right]$, burnt out of Spinifex, 14 June 1956, G.F. Gross (SAM OM1389).

\section{Paratype:}

Australia: South Australia: 1 ô, without data (SAM E220) (not examined). 


\section{Other material}

Australia: South Australia: 1 ô, Eyre Peninsula, 27 km S. of Cowell, 3349'S, 136 $43^{\prime}$ E, 28 May 1979, B.Y. Main (WAM T72528).

\section{DIAGNOSIS}

The gonopods of this species are very similar in shape to those of an undescribed Antichiropus species found on the edge of the Nullarbor Plain in WA (C. Car and M. Harvey, unpublished data) except that A. mammillifer is much larger both in body and gonopods. The solenomere of A. mammillifer possesses a broad spoon shaped tip (Figures 13E, F) as do several other undescribed WA species, but the gonopod of $A$. mammillifer also carries a large curved bulbous femoral process (prof) that ends in a long sharp point (Figures 13D, E). The main femoral process (MFP) on the gonopod is serrated along one edge (Figure 13E). Antichiropus mammillifer also has well developed sternal processes (cones) on the fifth body ring (Figure $5 \mathrm{~B})$.

\section{DESCRIPTION}

Male

For a verbal description see Jeekel (1982). Figures $13 \mathrm{D}-\mathrm{G}$ are new images of the gonopod originally illustrated in Figure 1 (Jeekel 1982). Figures 13A-C illustrate the whole specimen and its dorsal view for the first time.

\section{Female}

Unknown.

\section{DISTRIBUTION}

This species is restricted to the Eyre Peninsula region of South Australia (Figure 25).

\section{REMARKS}

This is the only species of the genus Antichiropus that has been found outside WA. It is also one of the largest millipedes in this genus (Figures 13A-C) matched in size only by $A$. variabilis.
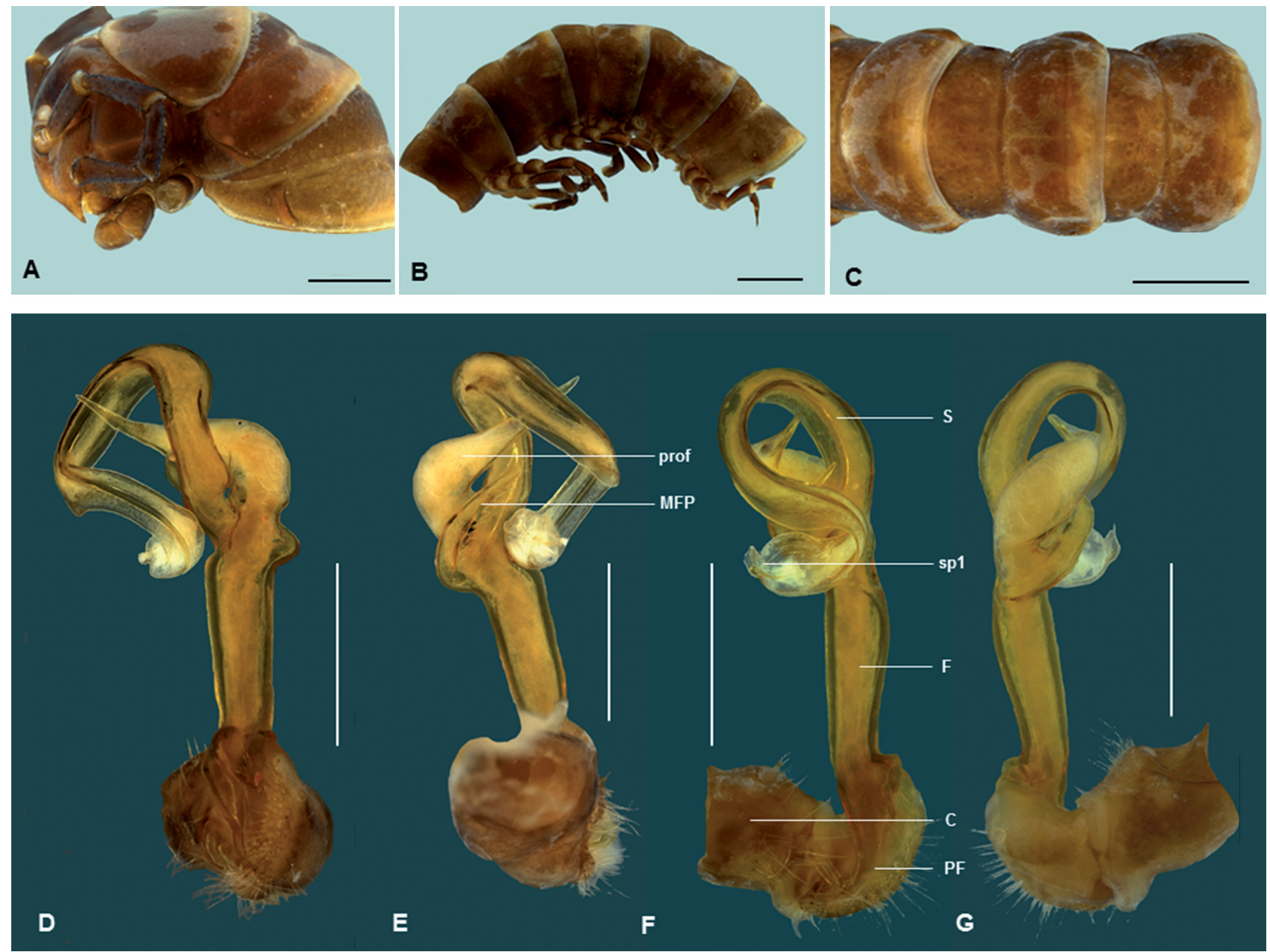

FIGURE 13 Antichiropus mammillifer Jeekel, holotype male (SAM OM1389): A, head, lateral view; B, mid-body, lateral view; C, mid-body, dorsal view; D-G, right gonopod image flipped: D, posterior view; E, anterior view; F, medial view; $G$, lateral view. Abbreviations: C, coxa; F, femur; MFP, main femoral process; PF, prefemur; prof, prolongation of femur; S, solenomere; sp1, solenomere process 1. Scale bars: $A=1 \mathrm{~mm} ; B-C=2 \mathrm{~mm}$; $-\mathrm{G}=1 \mathrm{~mm}$. 


\section{Antichiropus minimus Attems, 1911}

Figures 14,23

Antichiropus minimus Attems, 1911: 173, Figure 31.

\section{MATERIAL EXAMINED}

\section{Lectotype (new designation)}

Australia: Western Australia: ${ }^{\lambda}$ with gonopods attached: Mundaring Weir [31 $57^{\prime} \mathrm{S}, 116^{\circ} 09^{\prime} \mathrm{E}$ ], Hamburger südwest-australischen Forschungsreise
Station 101, 9 August 1905, W. Michaelsen and R. Hartmeyer (NHMW 3433).

\section{Paralectotypes}

Australia: Western Australia: 1 (gonopod only, slide mounted), collected with lectotype (NHMW 3433); 1 ก (badly damaged, without gonopods), collected with lectotype (ZMB 5153); 1 त, Jarrahdale [32 $\left.20^{\prime} \mathrm{S} 116^{\circ} 04^{\prime} \mathrm{E}\right]$, Hamburger südwest-australischen Forschungsreise Station 129, 19 September 1905, W. Michaelsen and R. Hartmeyer (ZMH).
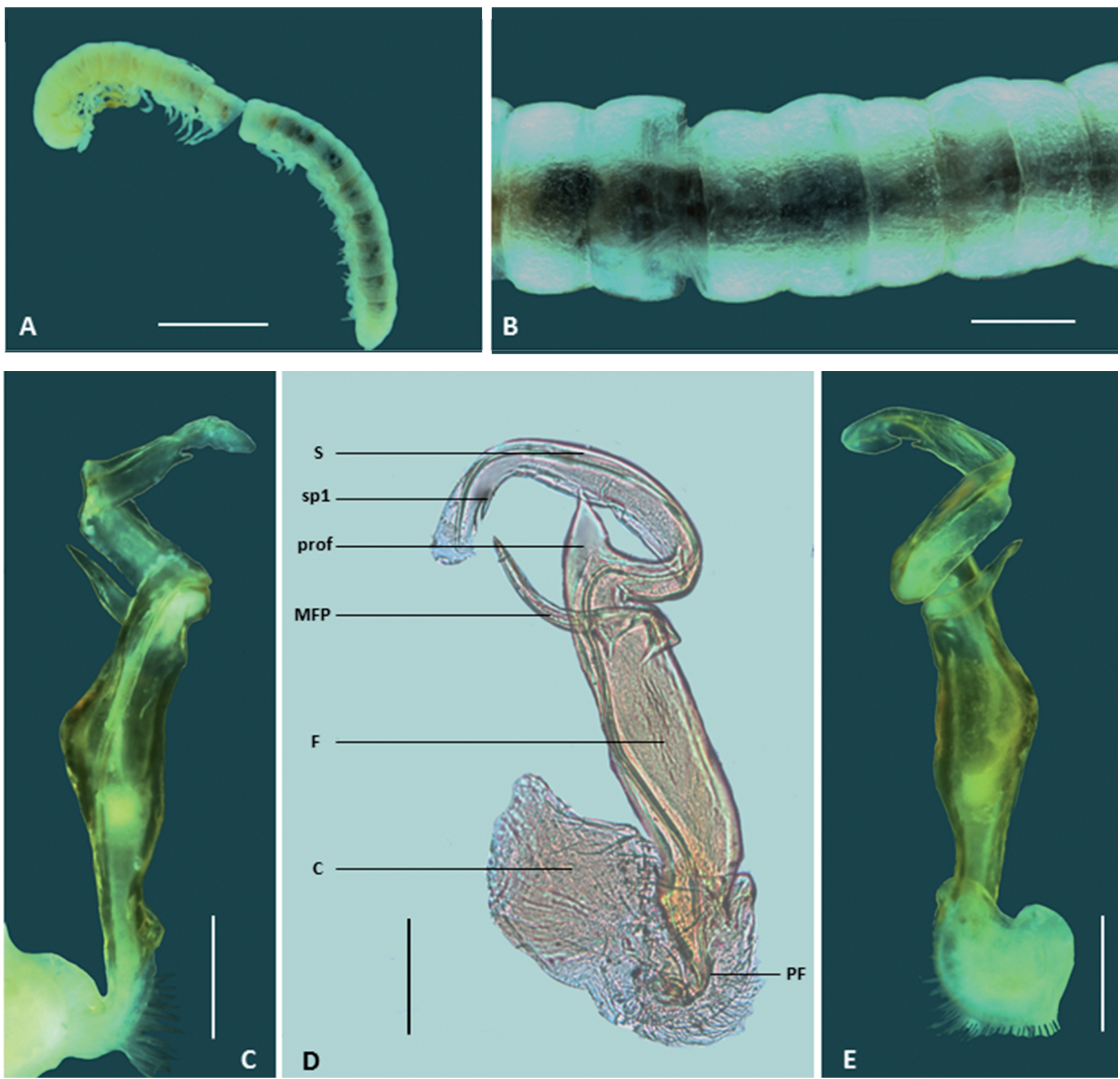

FIGURE 14 Antichiropus minimus Attems: A-B, lectotype male (NHMW 3433) habitus: A, lateral view; B, dorsal view; C-E, left gonopod, lectotype male (NHMW 3433): C, medial; E, lateral view; D, paralectotype male (NHMW 3433): right gonopod slide mounted medial view. C, coxa; F, femur; MFP, main femoral process; PF, prefemur; prof, prolongation of femur; $\mathrm{S}$, solenomere; sp1, solenomere process 1. Scale bars: $A=2 \mathrm{~mm} ; B=0.5 \mathrm{~mm}$; $\mathrm{C}-\mathrm{E}=0.2 \mathrm{~mm}$. 


\section{Other material}

There are no known additional specimens.

\section{DIAGNOSIS}

This species is by far the smallest in the genus. It has a relatively simple gonopod with a curved pointed main femoral process, the prolongation of the femorite pointed and broadly triangular, and the solenomere tip with a small spine-like process (Figure 14D).

\section{DESCRIPTION}

\section{Male (lectotype)}

Body approximately $10 \mathrm{~mm}$ long; midbody ring approximately $1 \mathrm{~mm}$ wide with less pronounced waist between prozonite and metazonite of similar width. Colour (of lectotype $\lesssim$ ) bleached in alcohol; legs with coloration similar to that of body. Paranota on all but first few body rings absent (Figure 14B). Sternites, other than those of the 5 th body ring, with no noticeable features; sternites of 5th body ring without obvious processes/tubercles; sternal lamella seemingly rounded (e.g. Figure 6). Anterior spiracles at midbody indistinct. Head smooth, without noticeable sculpturing. Frons smooth, with some setae. Face relatively broad; distance between antennal sockets (s) approximately $2.25 \mathrm{x}$ width of antennal socket (d) (Figure 8). Antennae of moderate length, extending approximately to first body ring behind collum, antennomeres similar in width and relatively robust (Figure 14A). Collum $0.75 \mathrm{x}$ as long as head (in lateral view). Gonopods of medium length, extending to posterior edge of 5 th body ring; coxa (C) much more robust, probably longer than femorite; prefemur (PF) somewhat shorter than femorite, ovoid; femorite (F) contributing to approximately two thirds or more of vertical acropodite height, upright, relatively slender at base, thickest at mid length and becoming thinner again at apex; main femoral process (MFP) relatively short, slender, pointed, held at an angle of approximately $45^{\circ}$ to the femorite; prolongation of femorite apex (prof) present on specimen as broadbased, triangular pointed structure but on slide preparation, no obvious prof; solenomere (S) relatively short, held in short spiral; solenomere tip with single apparently rounded end; solenomere process (sp1) near solenomere tip, short, spine-like (Figures 14C-E).

\section{Female}

Unknown.

\section{REMARKS}

Only two images of the lectotype gonopods could be taken as they are in situ and could not be dissected from the body. These images do not correspond to the diagram in Attems' paper because no prolongation of the femur on the lectotype gonopod is evident. All existing specimens are, however, tiny and badly damaged. The slide preparation of the paralectotype gonopod clearly shows the femur prolongation but has flattened the structure so it is difficult to describe, particularly as no new specimens have been found.

This species has been recorded from Mundaring Weir and Jarrahdale, approximately $60 \mathrm{~km}$ to the SSW (Figure 23). With a few notable exceptions, described in this paper, most Antichiropus species have very small species ranges (Harvey, 2002). Since A. minimus is a tiny species, we believe that records of its relatively wide distribution should be viewed with caution. Further, if another specimen from Yallingup does exist, it is highly unlikely that it represents $A$. minimus, as this locality is approximately $220 \mathrm{~km} \mathrm{SW}$ of Jarrahdale. Only the collection of more specimens would resolve the issue of whether the existing specimens are correctly labelled and/or identified.

Mesibov (2013b) lists a specimen recorded by Weidner (1960) from Yallingup, WA, collected by Michaelsen and Hartmeyer on 5 October 1905 at Station 150. This specimen is recorded as housed in the $\mathrm{ZMH}$ : MSH borrowed all material from $\mathrm{ZMH}$ and found only the male specimen listed above.

\section{Antichiropus monacanthus Attems, 1911}

Figures 15, 22

Antichiropus monacanthus Attems, 1911: 175, figures 34-36.

\section{MATERIAL EXAMINED}

\section{Lectotype (new designation)}

Australia: Western Australia: $\widehat{A}$ with gonopods originally removed for slide mounting but now in separate vial: Wooroloo [31 $\left.48^{\prime} \mathrm{S}, 116^{\circ} 19^{\prime} \mathrm{E}\right]$, Darling Ranges, 217 m, Hamburger südwest-australischen Forschungsreise Station 98, 29 May 1905, W. Michaelsen and R. Hartmeyer (NHMW 3437).

\section{Paralectotypes}

Australia: Western Australia: All specimens collected by W. Michaelsen and R. Hartmeyer during the Hamburger südwest-australischen Forschungsreise: 1 o gonopod only, collected with lectotype (NHMW 3437); 1 (with one broken gonopod), collected with lectotype $(\mathrm{ZMH}) ; 1$ q (damaged), Brown Station, Dirk Hartog Island $\left[26^{\circ} 00^{\prime} \mathrm{S} 113^{\circ} 10^{\prime} \mathrm{E}\right]$, Station 67, 21 June 1905 (ZMH); 1 juvenile, same details, but 7 -12 June 1905 (WAM T273; original number WAM 13/7152); 1 , Tamala in Edel Land [26 $41^{\prime} \mathrm{S}, 113^{\circ} 41^{\prime} \mathrm{E}$ ], WA, Australia, Station 70, 7-8 September 1905 (ZMB 5155).

\section{Other material}

There are no known additional specimens.

\section{DIAGNOSIS}

Antichiropus monacanthus may be recognised by a combination of features: a very long, straight femorite and a solenomere tip that tends to an apical point with small serrations. In addition, the solenomere process is large and pointed with a broad base, forming a clawlike shape (Figures 15D, F) with an extra small pointed 

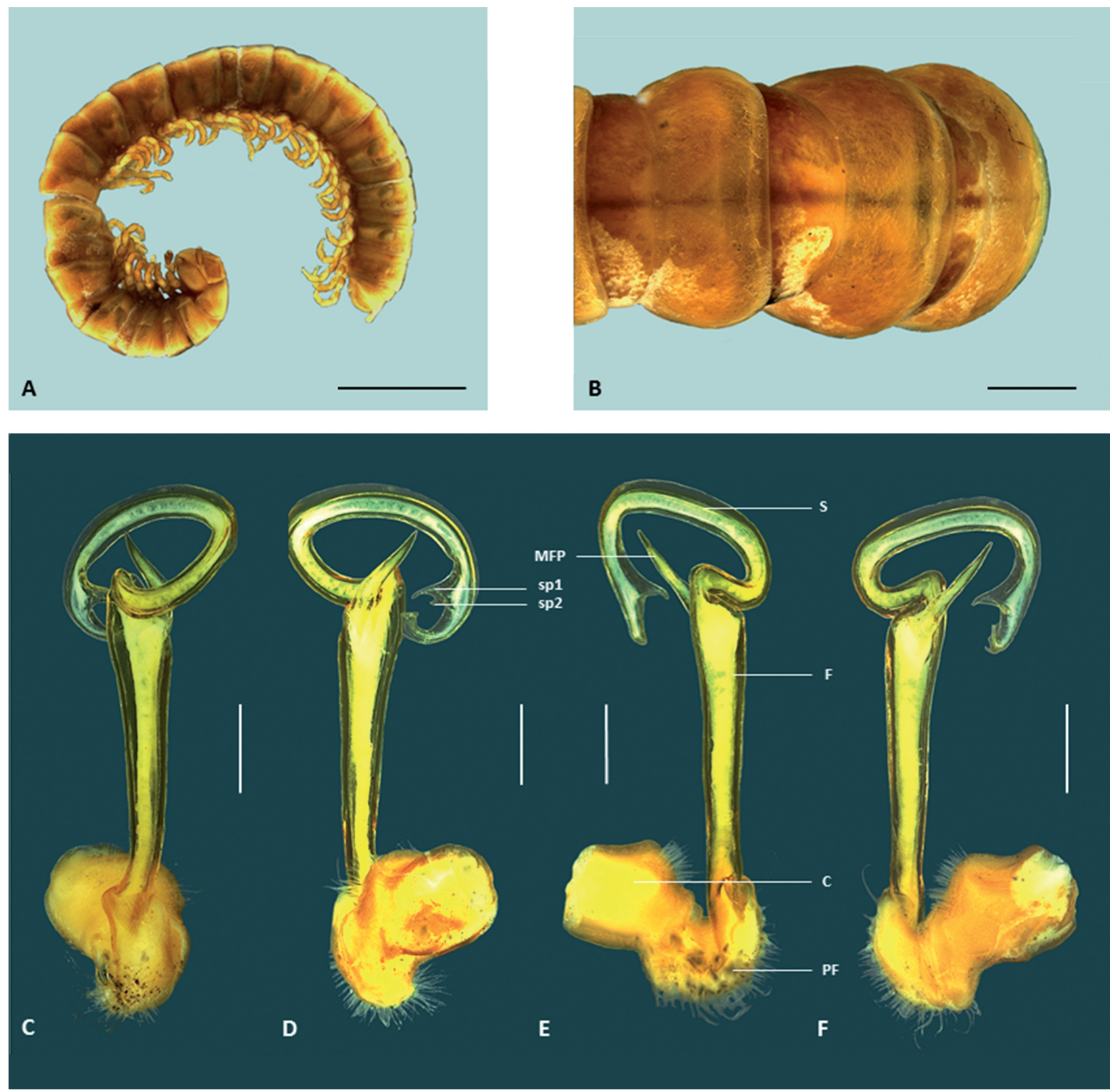

FIGURE 15 Antichiropus monacanthus Attems, lectotype male (NHMW 3437): A-B, habitus: A, lateral view; B, dorsal view; C-F, left gonopod: C, posterior view; D, anterior view; E, medial view; F, lateral view. Abbreviations: C, coxa; F, femur; MFP, main femoral process; PF, prefemur; S, solenomere; sp1 and sp2, solenomere processes 1 and 2. Scale bars: $A=5 \mathrm{~mm} ; B=1 \mathrm{~mm} ; C-F=0.5 \mathrm{~mm}$.

process at its base. The main femoral process is long, relatively slender and pointed and extends at 45 degrees from the femorite (Figures 15C-F).

\section{DESCRIPTION}

\section{Male (lectotype)}

Body approximately $35 \mathrm{~mm}$ long; midbody ring approximately $3 \mathrm{~mm}$ wide with distinct waist between prozonite and metazonite; metazonite wider than prozonite. Colour (of lectotype 3 ): probably bleached in alcohol (Figure 15A); legs with coloration similar to that of body. Paranota on all but first few body rings absent. Sternites, other than those of 5th body ring, with no noticeable features; sternites of 5th body ring without obvious processes/tubercles; sternal lamella broad, mushroom shaped. Anterior spiracles at midbody prominent, folded. Head smooth, without noticeable sculpturing. Frons smooth, with some setae. Face narrow, cardines and stipites clearly visible when animal is viewed 'face on'; distance between antennal sockets (s) approximately $2.5 \mathrm{x}$ width of antennal 
socket (d) (Figure 8). Antennae of moderate length, extending approximately to first body ring behind collum, not obviously clavate, 5th and 6th antennomeres only slightly wider than proximal ones, antennomeres relatively robust. Collum $1 \mathrm{x}$ as long as head (in lateral view) (Figures 15A, B). Gonopods of medium length, extending to posterior edge of 5th body ring; coxa (C) stouter, shorter than femorite, with noticeable ridge on anterior surface; prefemur (PF) considerably shorter than femorite, ovoid; femorite (F) contributing to approximately two thirds or more of vertical acropodite height, upright, and thickening towards its apex; main femoral process (MFP) long (as long as one quarter or more of solenomere length), slender, pointed; second femoral process (fpl) absent; prolongation of femorite apex (prof) absent; solenomere (S) relatively short, forming a circle, much thinner than femorite, and of similar thickness along its length; solenomere tip pointed, with serrations; solenomere process (spl) in apical third of solenomere, prominent, pointed, curved, broad; a second solenomere process (sp2) at base of main solenomere process, small, pointed (Figures15C-F).

\section{Female}

It seems likely that there is no female specimen available.

\section{REMARKS}

The NHMW collection consists of $1 \hat{\jmath}, 1$ set of unattached gonopods removed from a slide and 1 gonopod, all from Wooroloo (Figure 22). It is likely that the separate pair of gonopods belong to the lectotype $\hat{\sigma}$ with which they are housed, and that the single gonopod belongs to the paralectotype $\delta$ collected with the lectotype and housed in the ZMH. It is unlikely that the paralectotypes housed at the ZMH and WAM from Dirk Hartog Island and that kept at the ZMB from Tamala are the same species as A. monacanthus as both localities are at least $800 \mathrm{~km} \mathrm{NNW}$ of the type locality (Wooroloo). These specimens are either female or juvenile. To date, no further specimens have been collected from Wooroloo despite repeated attempts.

\section{Antichiropus nanus Attems, 1911}

Figures, 16, 22

Antichiropus nanus Attems 1911: 172, figures 29, 30.

\section{MATERIAL EXAMINED}

\section{Lectotype (new designation)}

Australia: Western Australia: ô with gonopods

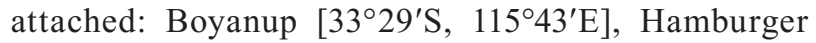
südwest-australischen Forschungsreise Station 146, 1-3 August 1905, W. Michaelsen and R. Hartmeyer (NHMW 3438).

\section{Paralectotypes}

Australia: Western Australia: 1 बै (gonopods only), collected with lectotype (NHMW 3438); 1 त (without gonopods) collected with lectotype (ZMB 5152); 1 ㅇ,
Yallingup $\left[33^{\circ} 38^{\prime} \mathrm{S}, 115^{\circ} 01^{\prime} \mathrm{E}\right]$, Station 150,5 October 1905 (ZMH).

\section{Other material}

Australia: Western Australia: 1 के, Boyanup picnic

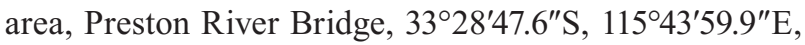
30 July 2012, collected by hand from leaf litter, C.A. Car, G.B. Hughes, J.M. Waldock (WAM T126103); 1 ô, Wellington National Park, Lennard Drive, near Rapids Picnic Ground, 3323'59"S, 115 57'52"E, 25 September 2010, sifting elevated litter in jarrah forest with Agonis, M. Rix, J. Wojcieszek (WAM T126022); 1 ऽ, Ironstone

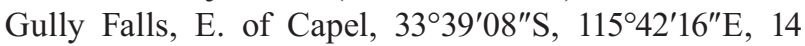
October, 2012, in wet leaf litter in deep crack in boulder, J.M. Waldock, S. Hill (WAM T126112).

\section{DIAGNOSIS}

This small species (Figures 16A, B) is different because it has two processes near the tip of the gonopod solenomere, the smaller of which is divided into two distinct pointed branches, a distinctively shaped main femoral process (Figures 16C, D) and a large broadbased prolongation of the femur, leaf like in shape and broadly pointed at its tip (Figures $16 \mathrm{C}-\mathrm{F}$ ).

\section{DESCRIPTION}

\section{Male (lectotype)}

Body approximately $18 \mathrm{~mm}$ long; midbody ring approximately $1.7 \mathrm{~mm}$ wide dorsally, with less pronounced waist, prozonite and metazonite of similar width. Colour of lectotype $\hat{\sigma}$ bleached in alcohol; of recent specimen (WAM T126103) dark brown (Figures $16 \mathrm{~A}, \mathrm{~B})$; legs with coloration similar to that of body. Paranota on all but first few body rings absent. Sternites, other than those of the 5th body ring, with no noticeable features; sternites of 5th body ring without obvious processes/tubercles: sternal lamella square. Anterior spiracles at mid-body prominent, folded. Head smooth, without noticeable sculpturing. Frons smooth, with some setae. Face narrow, the cardines and stipites clearly visible when the animal is viewed 'face on'; distance between antennal sockets (s) approximately $1.5 \mathrm{x}$ width of antennal socket (d) (Figure 8). Antennae of moderate length, extending approximately to the first body ring behind collum, not obviously clavate, 5th and 6th antennomeres only slightly wider than proximal ones, antennomeres relatively robust. Collum $0.75 \mathrm{x}$ as long as head (in lateral view) (Figures 16A, B). Gonopods of medium length, extending to posterior edge of 5 th body ring. Coxa (C) broader, stouter than femorite, with no noticeable processes; prefemur (PF) considerably shorter than femorite, ovoid; femorite (F) contributing to approximately two thirds or more of total vertical height of acropodite, upright, and of similar thickness along length; main femoral process (MFP) thick and long, at least half as long as solenomere, pointed, but not spine like, hatchet shaped; second femoral process (fp1) absent; prolongation of femorite apex (prof) present, large, broad at base, flattened, triangular in medial view; solenomere (S) relatively short, forming a circle, much 

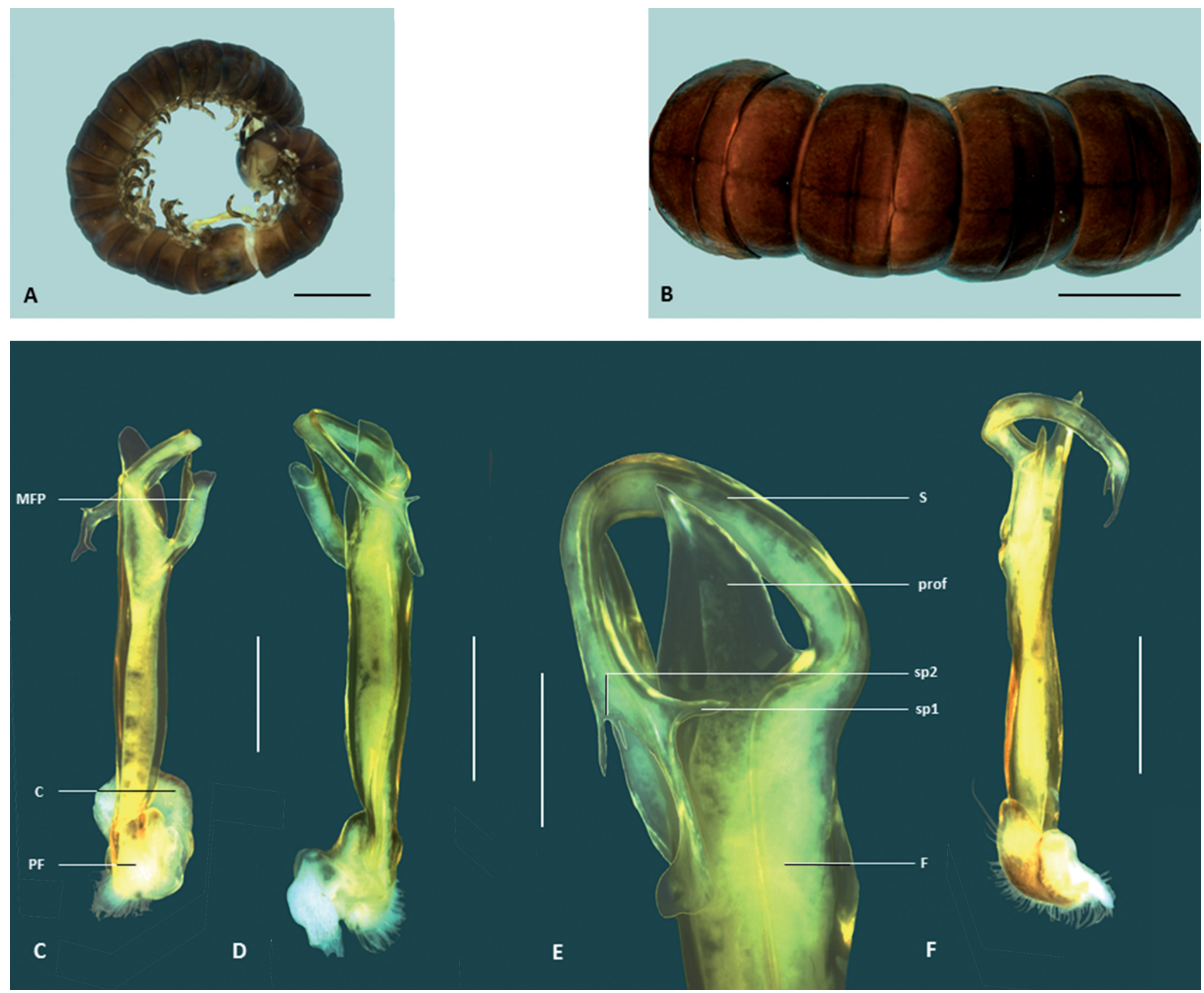

FIGURE 16 Antichiropus nanus Attems, male (WAM T126103): A-B, habitus: A, lateral view; B, dorsal view; C-F, left gonopod: C, posterior view; D, anterior view; , antero-medial view of solenomere tip; $F$, lateral view. Abbreviations: C, coxa; F, femur; MFP, main femoral process; PF, prefemur; prof, prolongation of femur; $S$, solenomere; sp1 and sp2, solenomere processes 1 and 2 . Scale bars: $A=5 \mathrm{~mm} ; \mathrm{B}=1 \mathrm{~mm} ; \mathrm{C}-\mathrm{F}=0.5 \mathrm{~mm}$.

more slender than femorite, thickest at base, thinner midlength, becoming thicker again at tip; solenomere tip with no serrations, single flattened, rounded end; solenomere process 1 (spl) in apical third of solenomere, prominent, pointed, upright, slender; second solenomere process (sp2) in apical third of solenomere, prominent, pointed with two branches (Figures 16C-F).

\section{Female}

Probably unknown (see Remarks).

\section{DISTRIBUTION}

This species is confined to an area south of Perth near Boyanup (Figure 22).

\section{REMARKS}

It is unlikely that the $q$ collected from Yallingup is the same species: the distance between Yallingup and
Boyanup is $90 \mathrm{~km}$ and there have been no males of the species collected to confirm the Yallingup identification. Images were taken of recently collected specimens as the type material is in poor condition.

\section{Antichiropus sulcatus Attems, 1911}

Figures 17, 22

Antichiropus sulcatus Attems, 1911: 177, Figures 39-41.

\section{MATERIAL EXAMINED}

\section{Lectotype (new designation)}

Australia: Western Australia: ô with gonopods attached: Guildford [31 $54^{\prime} \mathrm{S}, 115^{\circ} 58^{\prime} \mathrm{E}$ ], Hamburger südwest-australischen Forschungsreise Station 103, 19 May 1905, W. Michaelsen and R. Hartmeyer (NHMW 3435). 


\section{Paralectotypes}

Australia: Western Australia: $1 \hat{O}$ (damaged), collected with lectotype (NHMW 3435); 1 ठ (gonopods only), collected with lectotype (NHMW 3435); 1 ๙ (intact), 1 \&, collected with lectotype (ZMH).

\section{Other material}

Australia: Western Australia: 1 ô, Eneabba, AMC Mine, $29^{\circ} 49^{\prime} \mathrm{S}, 115^{\circ} 16^{\prime} \mathrm{E}$, 8 June 1988 , R.P. McMillan (WAM T72021); 2 ô, 1 क, Eneabba, R.G.C. Mineral Sands mine, $29^{\circ} 50^{\prime} \mathrm{S}, 115^{\circ} 15^{\prime} \mathrm{E}, 30$ May 1995, R.P. McMillan (WAM T72022); 1 ô, Eneabba, R.G.C. Mineral Sands mine, site 3, $29^{\circ} 56^{\prime} \mathrm{S}, 115^{\circ} 17^{\prime} \mathrm{E}, 5$ August 1998, PVC pitfall traps, P. West et al. (WAM T72023); $1 \hat{\mathrm{O}}$, same details, site $4,29^{\circ} 56^{\prime} \mathrm{S}, 115^{\circ} 17^{\prime} \mathrm{E}, 8$ August 1998, PVC pitfall traps, P. West et al. (WAM T72024); 1 ô, 1 +, $5 \mathrm{~km} \mathrm{NE}$. of Mt Lesueur, $30^{\circ} 09^{\prime} \mathrm{S}, 115^{\circ} 14^{\prime} \mathrm{E}$, 8 July 1989, by hand under blackboy $\log$, K. Gaull et

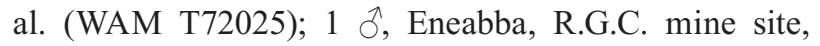
rehabilitation site $3,29^{\circ} 56^{\prime} \mathrm{S}, 115^{\circ} 17^{\prime} \mathrm{E}, 15$ May 1991 , R.P. McMillan (WAM T72026); 1 + , same details, rehabilitation site $6,29^{\circ} 56^{\prime} \mathrm{S}, 115^{\circ} 17^{\prime} \mathrm{E}, 21$ June 1989 , R. P. McMillan (WAM T72027); 1 ○, 1 †, same details, rehabilitation site 4, $29^{\circ} 49^{\prime} \mathrm{S}, 115^{\circ} 16^{\prime} \mathrm{E}, 21$ August 1991, R.P. McMillan (WAM T72028); 2 , Eneabba, AMC mine site, area $\# 5,29^{\circ} 49^{\prime} \mathrm{S}, 115^{\circ} 16^{\prime} \mathrm{E}, 23$ November 1987, R.P. McMillan (WAM T72029); 8 §, 2 ㅇ, same locality, area \#6, $29^{\circ} 49^{\prime} \mathrm{S}, 115^{\circ} 16^{\prime} \mathrm{E}, 8$ June 1988 , R. P. McMillan (WAM T72030); 1 o, $10 \mathrm{~km} \mathrm{S.} \mathrm{of} \mathrm{Eneabba,}$ R.G.C. Mineral Sands mine, site 7, $29^{\circ} 56^{\prime} \mathrm{S}, 115^{\circ} 17^{\prime} \mathrm{E}$, 8 August 1998, P. West (WAM T72748); 2 ô, same details (WAM T72753-4); 2 \%, same details, site 8 (WAM T72749, WAM T72751); 1 $\delta$, same details, site 3 (WAM T72750); 1 ${ }^{\wedge}, 10 \mathrm{~km} \mathrm{~S}$. of Eneabba, R.G.C. Mineral Sands mine, $29^{\circ} 56^{\prime} \mathrm{S}, 115^{\circ} 17^{\prime} \mathrm{E}$, August 1998, P. West (WAM T72752); 1 §, 10 km S. of Eneabba, R.G.C. Mineral Sands mine, control south, $29^{\circ} 56^{\prime} \mathrm{S}, 115^{\circ} 17^{\prime} \mathrm{E}, 7$ June 1998, R.P. McMillan (WAM T72755); 1 juvenile, Cooljarloo Mining Lease, between Brand Highway, Cooljarloo Road and Wongonderrah Road, 30 $40^{\prime} \mathrm{S}$, $115^{\circ} 25^{\prime} \mathrm{E}, 17-21$ August 2007, banksia low woodland on sand, M. Bamford (WAM T73489); 1 ^, 2 +, Cooljarloo, $260 \mathrm{~km} \mathrm{~N}$. of Perth, $30^{\circ} 39^{\prime} \mathrm{S}, 115^{\circ} 22^{\prime} \mathrm{E}$, October 2009, M. Bamford (WAM T98954, WAM T129142); 1 స, Eneabba, $29^{\circ} 49^{\prime} \mathrm{S}, 115^{\circ} 16^{\prime} \mathrm{E}, 23-30$ August 1998, pitfall traps, L. Bisevac (WAM T126073).

\section{DIAGNOSIS}

Antichiropus sulcatus has a distinctive prolongation of the femorite that carries a sharp point at its tip and appears as an asymmetrical leaf shape when viewed posteriorly and anteriorly (Figures 17D, E). In addition, the first solenomere process occurs almost halfway down the length of the solenomere as a broad short point where the solenomere thickens (Figure 17E). A second solenomere process occurs almost at the base of the solenomere but varies in size from a noticeably broad point to just a protuberance (Figure 17F).

\section{DESCRIPTION}

\section{Male (lectotype)}

Body approximately $25 \mathrm{~mm}$ long; midbody ring between 2.0-2.5 mm wide with distinct, lightly beaded waist between prozonite and metazonite of similar width. Colour (of lectotype ${ }^{A}$ ): bleached in alcohol, but more recent specimens show variation in colour from uniform dark brown (WAM T72030) to dark brown with pale longitudinal dorsal stripes (WAM T72024) (Figure 17B, C); legs with coloration similar to general body colour. Paranota on all but first few body rings present only as slight protuberances. Sternites, other than those of 5th body ring with protuberances on some anterior sternites; sternites of 5th body ring without obvious processes; sternal lamella broad, square tending towards helmet shaped (e.g. Figure 6F). Anterior spiracles at midbody, flat, folded (e.g. Figure 7B). Head smooth, without noticeable sculpturing. Frons smooth, with some setae. Face very narrow, the cardines and stipites clearly visible when the animal is viewed 'face on'; distance between antennal sockets (s) approximately $1 \mathrm{x}$ width of antennal socket (d). Antennae of moderate length, extending to first body ring behind collum, antennomeres of similar width to each other and relatively robust. Collum $0.75 \mathrm{x}$ length of head (Figure 17A). Gonopod (removed from slide and hence compressed antero-posteriorly) of medium length, extending to posterior edge of 5th body ring; coxa (C) stouter but of similar length to femorite, with noticeable ridge on anterior surface; prefemur $(\mathrm{PF})$ considerably shorter than femorite, ovoid; femorite (F) contributing approximately two thirds or more of vertical acropodite height, upright and thickening slightly towards apex; main femoral process (MFP) very long, at least half solenomere length, relatively slender, pointed, spear shaped; other femoral processes absent; prolongation of femorite (prof) present, large and leaf like with pointed apex; solenomere (S) relatively short, forming circle, generally more slender than femorite and thickest midway along its length; solenomere tip flattened; solenomere process (sp1) positioned approximately halfway along solenomere length, prominent, short, pointed, arising at thickest point of solenomere; solenomere process 2 (sp2) situated near base of solenomere, generally a stout, short point but may vary and appears to be absent in some specimens (Figures 17D-G).

\section{Female}

Recently collected female specimens show a similar variation in colour to the males, from uniform dark 

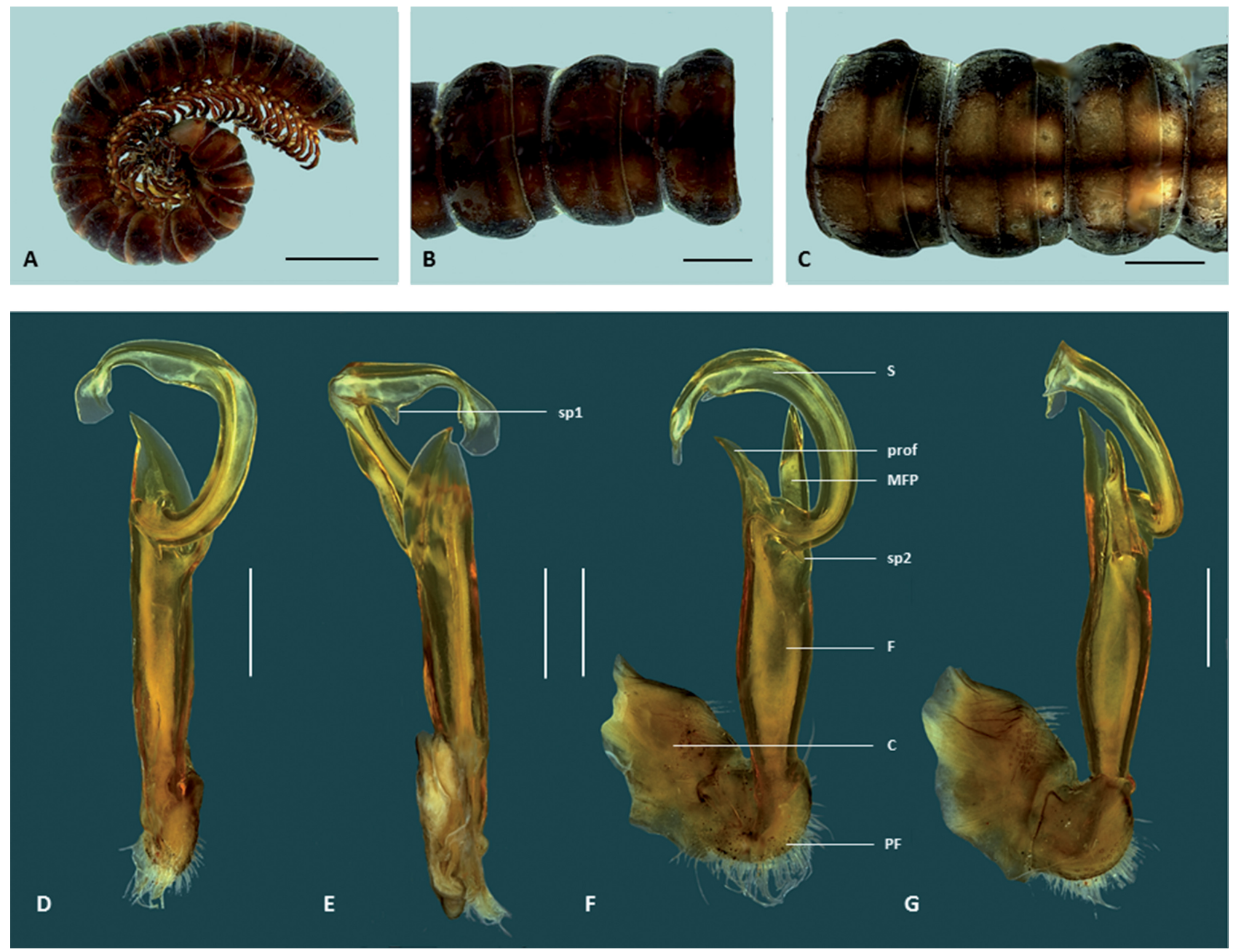

FIGURE 17 Antichiropus sulcatus Attems, male (WAM T72030): A-B, habitus: A, lateral view; B, dorsal view; C, male (WAM T72024) dorsal colour variation: D-G, lectotype male (NHMW 3435) right gonopod (image flipped): D, posterior view; E, anterior view; F, medial view; G, lateral view. Abbreviations: C, coxa; F, femur; MFP, main femoral process; PF, prefemur; prof, prolongation of femur; $\mathrm{S}$, solenomere; sp1 and sp2, solenomere processes 1 and 2. Scale bars: $A=5 \mathrm{~mm} ; B+C=1 \mathrm{~mm}$; $-G=0.5 \mathrm{~mm}$.

brown (WAM T72030) to dark brown with pale longitudinal dorsal stripes (WAM T72022); similar in length to males (approximately $25 \mathrm{~mm}$ ) but wider dorsally (2.5 $\mathrm{mm}$ and wider).

\section{DISTRIBUTION}

This species has been recently found near Eneabba (Figure 22). The original specimens were labelled Guildford, but as no further specimens have ever been collected in this area, we consider this record to be doubtful (see Remarks).

\section{REMARKS}

The NHMW and ZMB collections consist of identifiable males all labelled as collected from Guildford, near Perth in WA. No further specimens have been collected from this locality, but a number of specimens from the same species have been collected recently from Eneabba and vicinity, approximately 300 $\mathrm{km}$ north of Guildford, but not from the intermediate area. Although Michaelsen and Hartmeyer did not visit the Eneabba area, we believe that the Guildford specimens are incorrectly labelled.

\section{Antichiropus whistleri Attems, 1911}

Figures $5 \mathrm{~A}, 18,19,23$

Antichiropus whistleri Attems 1911: 174, figures 32, 33.

\section{MATERIAL EXAMINED}

\section{Lectotype (new designation)}

Australia: Western Australia: $\hat{\jmath}$ (broken, with right gonopod missing and left broken), Buckland Hill (near Fremantle) $\left[32^{\circ} 03^{\prime} \mathrm{S}, 115^{\circ} 44^{\prime} \mathrm{E}\right]$, Hamburger südwest- 
australischen Forschungsreise Station 114, 1 June 1905, W. Michaelsen and R. Hartmeyer (NHMW 3436).

\section{Paralectotypes}

Australia: Western Australia: 1 , same data as holotype (WAM T272); 1 क, same data except 21 May $1905(\mathrm{ZMH}) ; 1$ ઈ (left gonopod intact, right gonopod missing), Upper Blackwood District, Brancaster [32 ${ }^{\circ} 54^{\prime} \mathrm{S}, 116^{\circ} 34^{\prime} \mathrm{E}$ ], 1.V.1909, J.M. Whistler $(\mathrm{ZMH}) ; 1$ + (badly disintegrated), Rottnest Island $\left[31^{\circ} 59^{\prime} \mathrm{S}, 115^{\circ} 32^{\prime} \mathrm{E}\right]$, Hamburger südwest-australischen Forschungsreise Station 121, 6-13 September 1905, W. Michaelsen and R. Hartmeyer (ZMB 5154).

\section{Other material}

For all other specimens of $A$. whistleri examined, see Appendix 2.

\section{DIAGNOSIS}

This species may be distinguished by the long straight gonopodal femorite that extends into a large and broadly rounded process with slight striations at the tip (Figures 19A, B) and by the presence of a distinctive second solenomere process that characteristically bends back on itself in the apical third of the solenomere, almost like a turned back claw (Figures 19A, B).

\section{DESCRIPTION}

\section{Male (lectotype)}

Body 25-30 mm long; midbody ring approximately 2.5-3 mm wide with a lightly beaded distinct waist between prozonite and metazonite of similar width. Colour (of lectotype $\delta$ ) bleached by alcohol, but when alive, can vary from uniformly dark (WAM T130172) in specimens from the Perth area to dark with two pale dorsal stripes running the length of the body (WAM T126884) in specimens in the northernmost limits of the species range (Figures 18A, B); legs with coloration similar to that of general body. Paranota absent. Sternites, other than those of the 5th body ring, with no noticeable features; sternites of 5th body ring without obvious processes/tubercles; sternal lamella broad, square. Anterior spiracles at midbody prominent, folded. Head smooth, without noticeable sculpturing. Frons smooth, with some setae. Face broad, the cheeks at least partially obscuring the cardines, when viewed 'face on'; distance between antennal sockets (s) approximately $2 \mathrm{x}$ width of antennal socket (d) (Figure 8). Antennae of moderate length, extending approximately to the first body ring behind collum, the 5th and 6th antennomeres only slightly wider than proximal ones, antennomeres relatively robust. Collum $1 \mathrm{x}$ as long as head (in lateral view) (Figures 18A, B). Gonopods of lectotype $\widehat{\sigma}$ damaged. Male (WAM T53595): gonopods of medium length, extending to posterior edge of 5th body ring; coxa (C) stouter, and shorter than femorite, with noticeable ridge on anterior surface; prefemur (PF) considerably shorter than femorite, ovoid; femorite $(F)$ contributing to approximately two thirds or more of the total vertical height of the acropodite, upright, and thickening towards its apex. Main femoral process (MFP) long (as long as one quarter or more of solenomere length), pointed, but not spine-like, spear or flame shaped. No other femoral processes. Prolongation of femorite apex (prof) present, large, broadly triangular; solenomere (S): long enough to form more than one loop or circle, generally more slender than femorite; solenomere tip single, flattened, with no serrations. Solenomere process 1 (spl) closer to tip than base, prominent, pointed, curved, slender; second solenomere process (sp2) in apical third of solenomere, prominent, pointed, reminiscent of an extended thumb (Figures 19A-D).

\section{Female}

Colour, as with males, can vary from uniformly dark (WAM T73389) in specimens from the Perth area to dark with two pale dorsal stripes running the length of the body (WAM T126884) in specimens in the northernmost limits of the species range: of similar size to male, but slightly broader when viewed dorsally (3 $\mathrm{mm}$ and wider).

\section{REMARKS}

The lectotype of $A$. whistleri has damaged gonopods and those of the male paralectotype cannot be dissected from the body for detailed examination; a more recently collected specimen (WAM T53595) has been used for three of the four gonopod illustrations instead.

Attems (1911) lists a specimen of this species from Brancaster in the upper Blackwood district. It is likely that this specimen $(\mathrm{ZMH})$ has been incorrectly identified as, even after extensive surveys, no specimens of $A$. whistleri have been found south of the Swan River which flows through the city of Perth in WA (c. $32^{\circ}$ $03^{\prime} \mathrm{S}, 115^{\circ} 44^{\prime} \mathrm{E}$ ) and Brancaster is $220 \mathrm{~km}$ south of the Swan River. The specimen has one missing gonopod and the remaining gonopod (in situ) is obscured by the specimen's curled body such that the species cannot be positively identified. A paralectotype is also listed from Rottnest Island. No A. whistleri specimens have been collected from this island, although there is a different widespread undescribed species there (C. Car and M. Harvey, unpublished data). This paralectotype specimen is purportedly a female, but has disintegrated into tiny fragments and is impossible to identify with any certainty. The label accompanying this specimen states that the collection date was 6-13.X.1905, but Michaelsen and Hartmeyer (1907) recorded it as 6-13. IX. of that year, which appears to be the correct date. 
Attems (1911) also listed two specimens collected at the same time as the lectotype from Buckland Hill, under the manuscript name of Antichiropus 'michaelseni' (NHMW8071, 8072). The gonopods of NHMW8071 have been examined and are those of $A$. whistleri: those of NMHW8072 have been mounted on a slide which is now damaged. It seems likely that they also belong to $A$. whistleri.

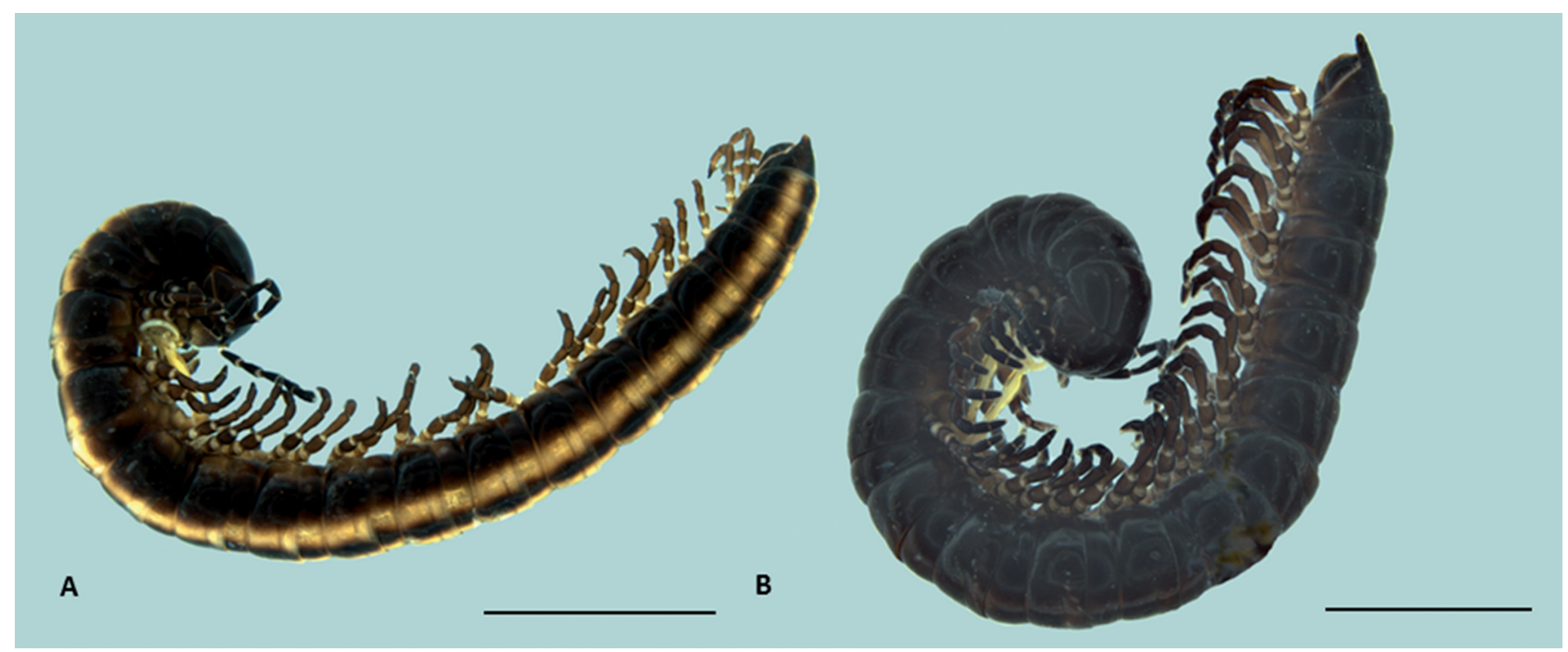

FIGURE 18 Male of Antichiropus whistleri Attems, showing colour variation: A, striped form (WAM T126884) from Cooljarloo, WA; B, dark form (WAM T130172) from Joondalup, WA. Scale bars $=5 \mathrm{~mm}$.

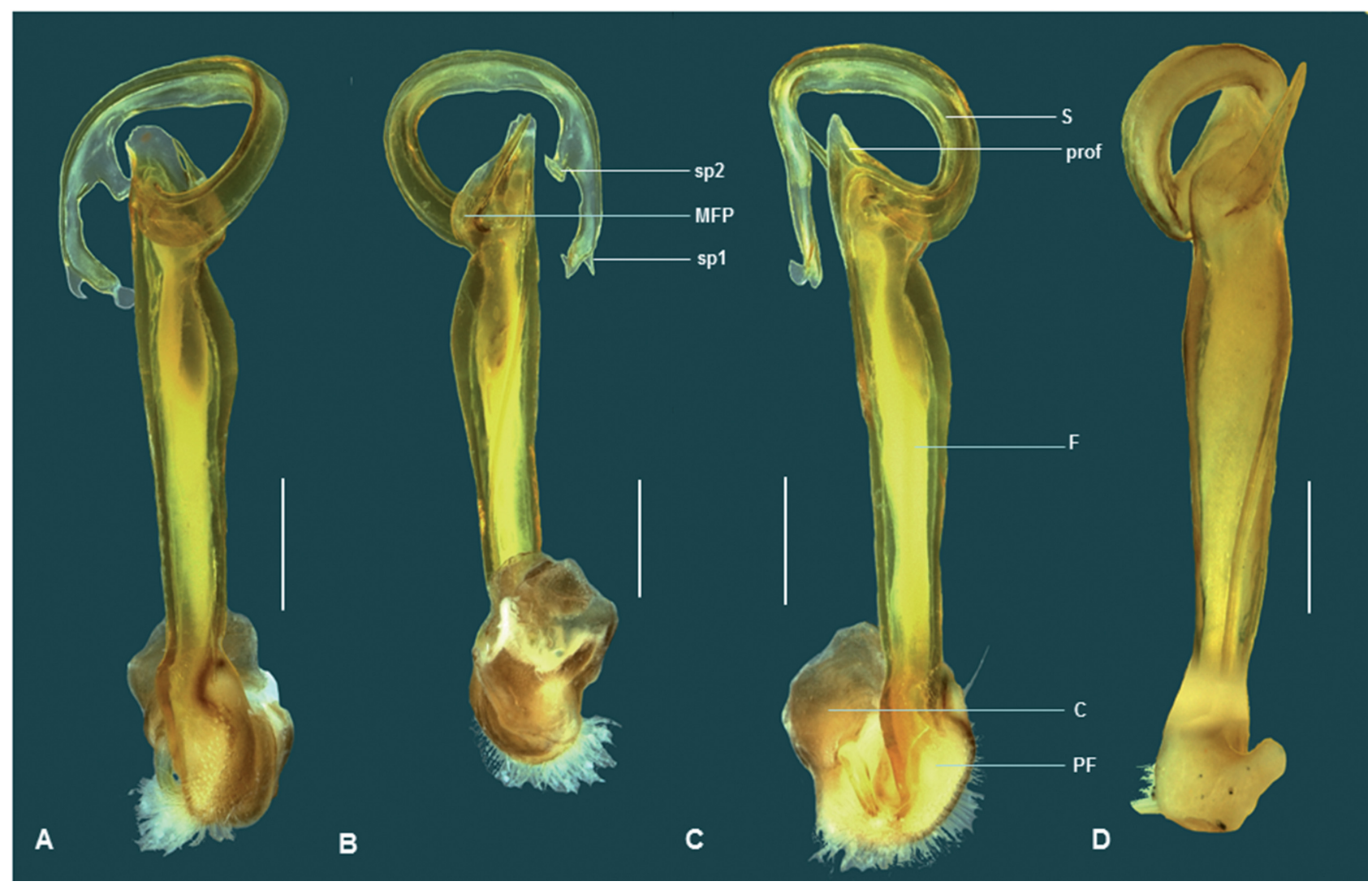

FIGURE 19 Antichiropus whistleri Attems: A-C, left gonopod, male (WAM T53595): A, posterior view; B, anterior view; C, medial view; D, left gonopod, lateral view, lectotype male (NHMW 3436). Abbreviations: C, coxa; F, femur; MFP, main femoral process; PF, prefemur; prof, prolongation of femur; $\mathrm{S}$, solenomere; sp1 and sp2, solenomere processes 1 and 2 . Scale bars: $A=5 \mathrm{~mm} ; B=1 \mathrm{~mm} ; C-F=0.5 \mathrm{~mm}$. 


\section{DISTRIBUTION}

Antichiropus whistleri is a widespread species, ranging from $30^{\circ} 35^{\prime} \mathrm{S}$ to $32^{\circ} 03^{\prime} \mathrm{S}$ and from $115^{\circ} 22^{\prime} \mathrm{E}$ to $115^{\circ} 54^{\prime} \mathrm{E}$ (Figure 23). No specimens have been found south of the Swan River, WA.

\section{DISCUSSION}

Although only nine Antichiropus species have been named in previous taxonomic work (Attems 1911; Jeekel 1982; Shear 1992), of which A. mammillifer is the only species known to occur outside WA, we are now aware of 160 new Antichiropus species in WA. Like most paradoxosomatids (Car 2010; Kime and Golovatch 2000) Antichiropus species have limited powers of dispersal and conservative ecological requirements. In addition, due to the semi-arid nature of much of WA, the above-ground activity of most Antichiropus species is limited to a very small window of opportunity when there is sufficient moisture for them to forage and mate. Antichiropus species are, consequently, short-range endemics with very small distributions (Harvey 2002). The genus is, therefore, species rich, and the gaps in the Antichiropus distribution map (Figure 20) suggest that more species are likely to be discovered.

This paper was prepared to provide modern redescriptions and images of the nine previously named species, and to stabilise the type localities of the seven species described by Attems (1911) which were uncertain due to his (sometimes erroneous) inclusion of females from different localities to that of the males. In addition, a redefinition of the genus Antichiropus has been provided: this should form the basis for many more new Antichiropus species descriptions. A second paper is already in preparation to describe 30 new species from the Great Western Woodlands region of WA (C. Car and M. Harvey, unpublished data).

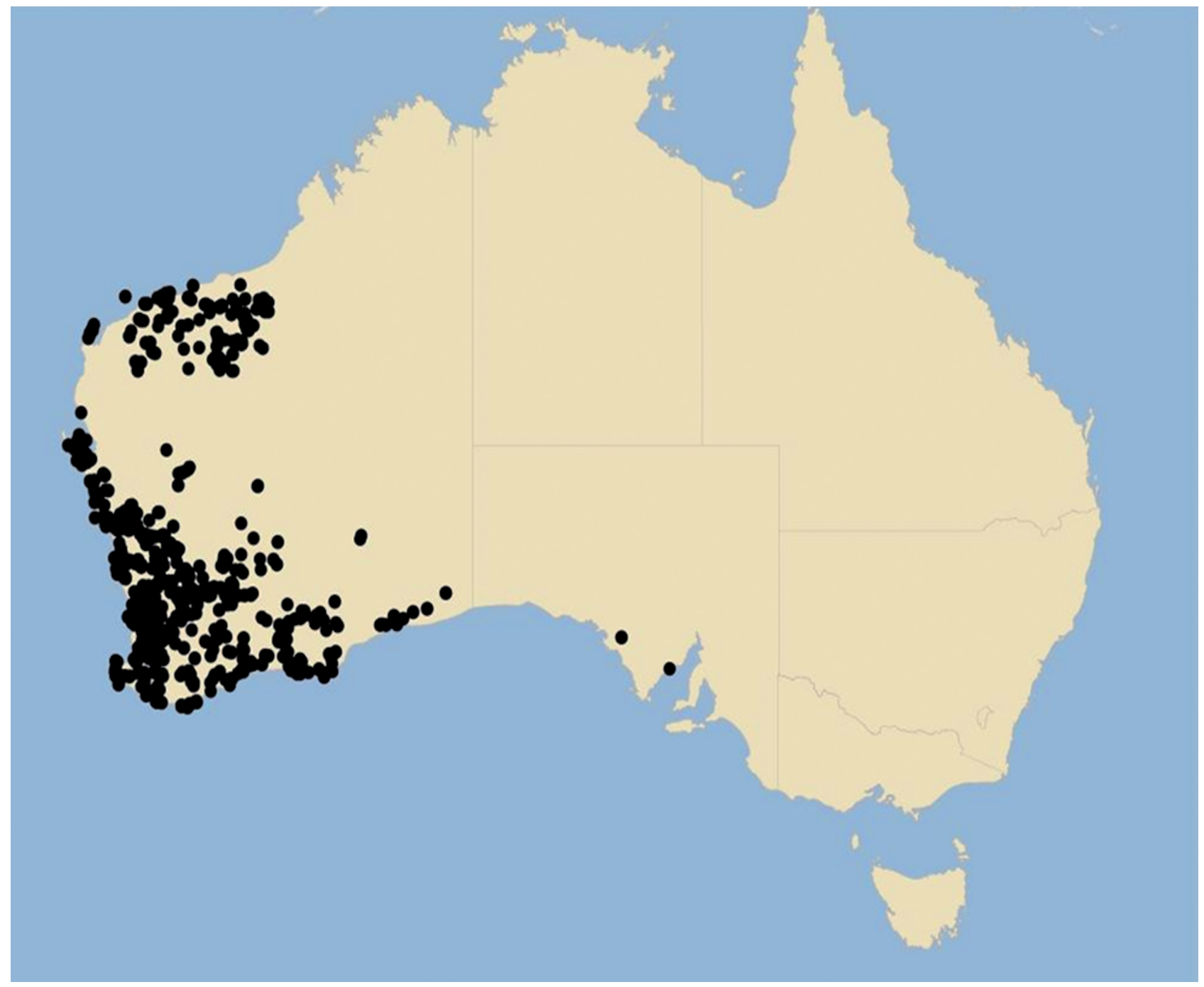

FIGURE 20 Recorded distribution of the genus Antichiropus in Australia (sites represented by black dots). 

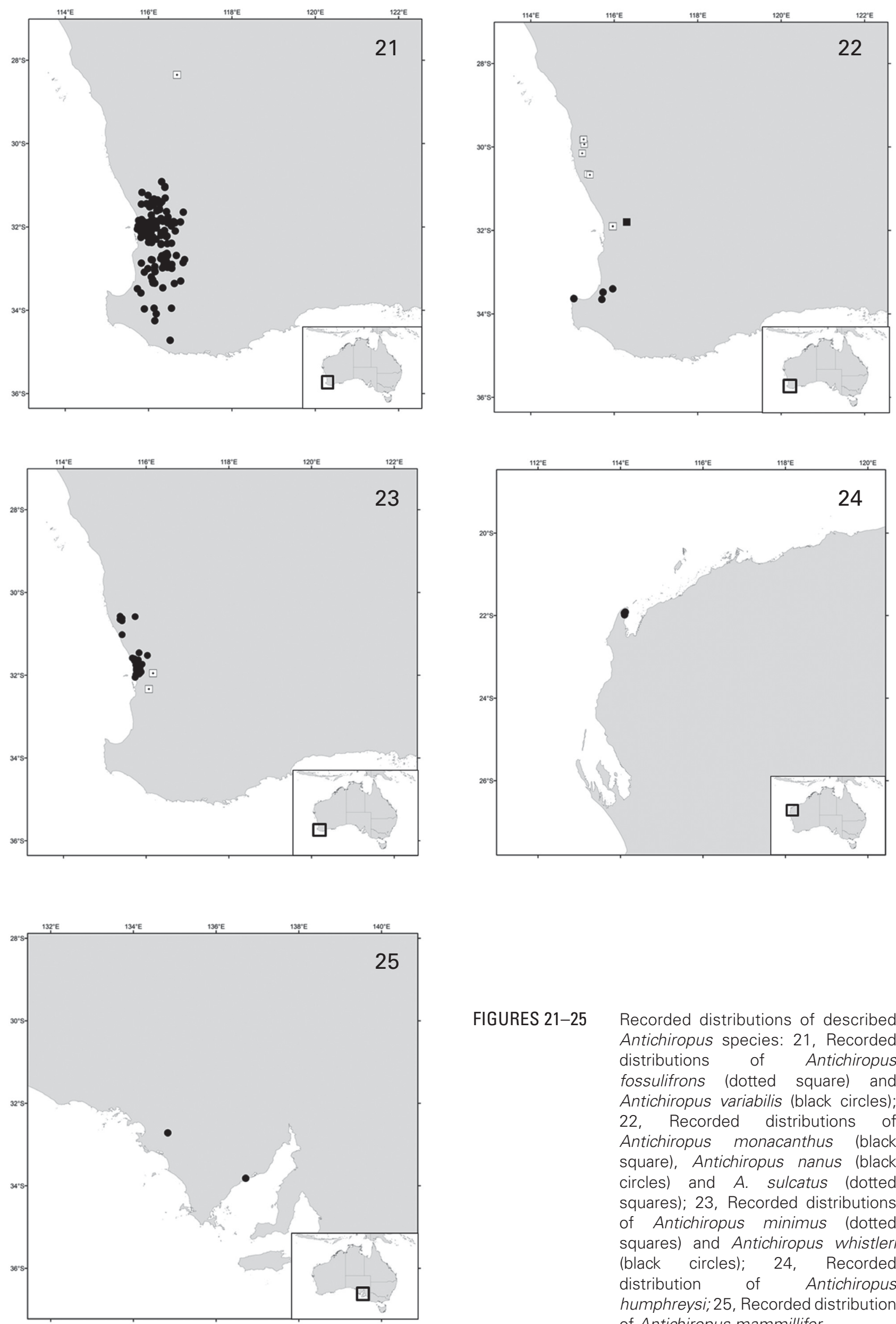

FIGURES 21-25 Recorded distributions of described Antichiropus species: 21, Recorded distributions of Antichiropus fossulifrons (dotted square) and Antichiropus variabilis (black circles); 22, Recorded distributions of Antichiropus monacanthus (black square), Antichiropus nanus (black circles) and $A$. sulcatus (dotted squares); 23, Recorded distributions of Antichiropus minimus (dotted squares) and Antichiropus whistleri (black circles); 24, Recorded distribution of Antichiropus humphreysi; 25, Recorded distribution of Antichiropus mammillifer. 


\section{ACKNOWLEDGEMENTS}

This project would not have been possible without the financial support of Cliffs Natural Resources, and we are extremely grateful to Paul West for his support of this study. We also gratefully acknowledge the assistance of Bruce Halliday (ANIC), Charles Griswold (CAS), Verena Staghl (NHMW), David Hirst (SAM), Jason Dunlop (ZMB) and Hieronymus Dastych (ZMH) for the loan of specimens in their care. Many thanks are due to Julianne Waldock for her valuable laboratory assistance, her enthusiasm and for the large number of specimens collected over many years. Other notable collectors include Alan Longbottom and Michael Rix, whom we gratefully acknowledge. We would also like to thank Robert Mesibov and Bill Shear who reviewed this paper and suggested many improvements.

\section{REFERENCES}

Attems, C.G. (1911). Myriopoda exk1. Scolopendridae. In: Michaelsen, W. and Hartmeyer, R. (eds.) Die Fauna Sudwest-Australiens. Ergebnisse der Hamburger südwest-australischen Forschungsreise 1905 3(6): 147204. Jena: Gustav Fischer.

Brölemann, H.W. (1916). Essai de classification des Polydesmiens (Myriapodes). Annales de la Société Entomologique de France 84: 523-608.

Brolemann, H.W. (1931). Myriapodes recueillis par Madame Pruvot en Nouvelle-Calédonie at aux Loyalty. Archives de Zoologie Expérimentale et Generale 72: 275-316.

Car, C.A. (2009). Keeled millipedes (Diplopoda: Polydesmida: Paradoxosomatidae) in New South Wales. General and Applied Entomology 38: 1-7.

Car, C.A. (2010). Pine plantations and native millipedes (Diplopoda: Polydesmida: Paradoxosomatidae) in southeastern New South Wales, Australia. Australian Journal of Entomology 49: 317-323.

Car, C.A. and Harvey, M.S. (2013). A review of the Western Australian keeled millipede genus Boreohesperus (Diplopoda, Polydesmida, Paradoxosomatidae). ZooKeys 290: $1-19$.

Chamberlin, R.V. (1920). The Myriopoda of the Australian Region. Bulletin of the Museum of Comparative Zoology 64: 1-269.

De Saussure, H. (1860). Essai d'une faune de Myriapodes du Mexique, avec la description de quelques espèces des autres parties de 1 Amérique. Mémoires de la Société de Physique et d'Histoire Naturelle de Genève 15: 259-394.

Harvey, M.S. (2002). Short-range endemism among the Australian fauna: some examples from non-marine environments. Invertebrate Systematics 16: 557-570.

Humbert, A. and De Saussure, H. (1869). Description de divers Myriapodes du Musee de Vienne. Verhandlungen der Kaiserlich-Königlichen Zoologisch-Botanischen Gesellschaft in Wien 19: 669-692.

Humphreys, W.F. and Shear, W.A. (1993). Troglobitic millipedes (Diplopoda: Paradoxosomatidae) from semiarid Cape Range, Western Australia: systematics and biology. Invertebrate Taxonomy 7: 173-195.

Jeekel, C.A.W. (1965). A new genus and a new species of the family Paradoxosomatidae from Australia (Diplopoda, Polydesmida). Entomologische Berichten (Amsterdam) 25: 7-14.

Jeekel, C.A.W. (1968). On the classification and geographical distribution of the family paradoxosomatidae. Rotterdam, Nederlandse Entomologische Vereniging 162 pp.

Jeekel, C.A.W. (1979). Notes on the classification of some little known Australian paradoxosomatid genera (Diplopoda, Polydesmida). Journal of Natural History 13: 649-658.

Jeekel, C.A.W. (1982). Millipedes from Australia, 1: Antichiropodini from South Australia (Diplopoda, Polydesmida, Paradoxosomatidae). Bulletin Zoölogisch Museum, Universiteit van Amsterdam 8: 121-132.

Jorgensen, M.C. and Sierwald, P. (2010). Review of the Caribbean pyrgodesmid genus Docodesmus Cook with notes on potentially related genera (Diplopoda, Polydesmida, Pyrgodesmidae). International Journal of Myriapodology 3: 25-50.

Kime, R.D. and Golovatch, S.I. (2000). Trends in the ecological strategies and evolution of millipedes. Biological Journal of the Linnean Society 69: 333-349.

Koch, C.L. 1847. System der Myriapoden mit Verzeichnissen und Berichtigungen zu Detschlands Crustaceen, Myriapoden und Arachniden, Regensburg, Pustet 270 pp.

Mesibov, R. (2008). Diversity of Queensland paradoxosomatid millipedes (Diplopoda: Polydesmida: Paradoxosomatidae). Australian Entomologist 35: 37-46.

Mesibov, R. (2013a). External Anatomy of Polydesmida http:// www.polydesmida.info/polydesmida/index.html Accessed October 2013.

Mesibov, R. (2013b). Millipedes of Australia. http://www. polydesmida.info/millipedesofaustralia/index.html. Accessed 3 October 2013.

Michaelsen, W. and Hartmeyer, R. (1907). Reisebericht pp.1116. In: Michaelsen, W. and Hartmeyer, R. (eds.) Die Fauna Südwest-Australiens. Ergebnisse der Hamburger südwest-australischen Forschungreise 1905. Jena: Gustav Fischer.

Rowe, M. and Sierwald, P. (2006). Morphological and systematic study of the tribe Australiosomatini (Diplopoda: Polydesmida: Paradoxosomatidea: Paradoxosomatidae) and a revision of the genus Australiosoma. Brölemann. Invertebrate Systematics 20: 527-556.

Shear, W.A. (1992). A new genus and two new species of millipedes from the Cape Range, Western Australia (Diplopoda, Polydesmida, Paradoxosomatidae). . Records of the Western Australian Museum 15: 777-784.

Verhoeff, K.W. (1924). Results of Dr. E Mjoberg's Swedish Scientific Expeditions to Australia 1910-1913. 34. Myriapoda: Diplopoda. Arkiv for Zoologi 16: 1-142.

Weidner, H. (1960). Die entomologische Sammlungen des Zoologischen Staatsinstituts und Zoologischen Museums Hamburg III Chilopoda und Progoneata. Mitteilungen aus dem Hamburgischen Zoologischen MuseumWojcieszek, 
J.M., Austin, P., Harvey, M.S. and Simmons, L.W. (2012). Micro-CT scanning provides insight into the functional morphology of millipede genitalia. Journal of Zoology 287: 91-95.

Wojcieszek, J.M., Harvey, M.S. and Rix, M.G. (2011). Optimised captive husbandry conditions for the Western Australian 'Marri Millipede'Antichiropus variabilis (Diplopoda: Polydesmida: Paradoxosomatidae) with notes on natural history and tissue preservation techniques. Records of the Western Australian Museum 26: 87-93.
Wojcieszek, J.M. and Simmons, L.W. (2012). Evidence for stabilizing selection and slow divergent evolution of male genitalia in the millipede Antichiropus variabilis. Evolution 66: 1138-1153.

Wojcieszek, J.M., Austin, P., Harvey, M.S. and Simmons, L.W. (2012). Micro-CT scanning provides insight into the functional morphology of millipede genitalia. Journal of Zoology 287: 91-95.

MANUSCRIPT RECEIVED 12 SEPTEMBER 2013; ACCEPTED 17 OCTOBER 2013. 
APPENDIX 1 All non-type material examined of Antichiropus variabilis.

Australia: Western Australia: 2 , Mundaring Weir [31 $\left.57^{\prime} \mathrm{S}, 116^{\circ} 09^{\prime} \mathrm{E}\right], 19$ October 1908, J. M. Giles

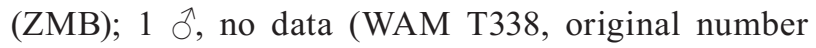
14/995); Cottesloe [3159'S, 115²5'E], 4 June 1913, T. Baker (WAM T287, original number 13/7325); 2 specimens, Gooseberry Hill [315 '20"S, $\left.116^{\circ} 02^{\prime} 52^{\prime \prime} \mathrm{E}\right], 1$ May 1915 (WAM T377, original

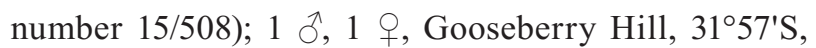
11603'E, 11-16 June 1964, E.J. Car (WAM T73393); 1 ô, Kalamunda, $31^{\circ} 58^{\prime} \mathrm{S}, 116^{\circ} 03^{\prime} \mathrm{E}, 19$ June 1963, J. Dell (WAM T72756); 1 ㅇ, NW. end of Ashendon Rd, Kalamunda, site 2, 32 $011^{\prime} 18^{\prime \prime} \mathrm{S}, 116^{\circ} 11^{\prime} 22^{\prime \prime} \mathrm{E}, 8$ October 2005, by hand, under Xanthorrhoea, G. Kendrick and M. Bunbury (WAM T73033); 1 ô, Hills Forest Discovery Centre, Allens Rd just off Mundaring Weir Rd, Kalamunda, $31^{\circ} 56^{\prime} \mathrm{S}, 116^{\circ} 11^{\prime} \mathrm{E}, 16$ September 2004, by hand, M.S. Harvey (WAM T73239); 1 o, Kalamunda National Park, on track beside Piesse Brook, 31 ${ }^{\circ} 58^{\prime} \mathrm{S}, 116^{\circ} 04^{\prime} \mathrm{E}, 29$ August 1999, by hand, J.M. Waldock (WAM T73397); 1 ते,South Bindoon, $31^{\circ} 23^{\prime} \mathrm{S}, 116^{\circ} 05^{\prime} \mathrm{E}$. (WAM T1583-5, original numbers 27/696-8); 2 o, Forrestdale, $32^{\circ} 09^{\prime} \mathrm{S}, 115^{\circ} 56^{\prime} \mathrm{E}, 2$ August 1932, U. Skeet (WAM T2396, T2397, original

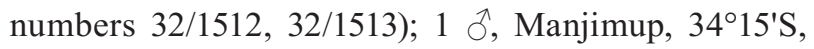
$116^{\circ} 09^{\prime} \mathrm{E}, 1$ July 1924, via Sunday Times (WAM T40669, original number 24/645); $3 \hat{\jmath}, 1$, Norman Road, Cardup, site NO1, 32 ${ }^{\circ} 16^{\prime} 08^{\prime \prime} \mathrm{S}, 116^{\circ} 00^{\prime} 44^{\prime \prime} \mathrm{E}, 16$ April - 17 June 1996, wet pitfall trap, J.M. Waldock, P. West and A.F. Longbottom (WAM T41669, T72768); 1 ふै, Cardup Reserve, site CR1, 32¹4'35"S, 11559'08"E, 16 April - 17 June 1996, wet pitfall trap, J.M. Waldock, P. West and A.F. Longbottom (WAM T72788); 1 §ै, 1 우, Cardup Reserve, site CR2, 32¹4'40"S, 11559'15"E, 16 April -17 June 1996, wet pitfall trap, J.M. Waldock, P. West and A.F. Longbottom (WAM T72789); 2 Õ, Brickwood Reserve, Cardup, site BR2, 32॰14'02"S, 116 00'07"E, 16 April-17 June 1996, wet pitfall trap, J.M. Waldock, P. West and A.F. Longbottom (WAM T72795); 1 , Kings Park, Perth, 31 ${ }^{\circ} 57^{\prime} \mathrm{S}, 115^{\circ} 50^{\prime} \mathrm{E}, 14$ June 2000, J.M. Waldock (WAM T42294); 1 §ै, Kings Park, near Saw Ave, $31^{\circ} 57^{\prime} \mathrm{S}, 115^{\circ} 50^{\prime} \mathrm{E}, 16$ June 2002 , by hand, M.S. Harvey et al. (WAM T46803); 5 ふ̃, 1 o, Kings

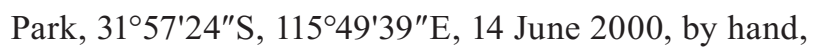
on cycleway in rain, J.M. Waldock (WAM T73382, T73386, T73387); 1 q, Kings Park, 3157'19"S, $115^{\circ} 50^{\prime} 00^{\prime \prime} \mathrm{E}, 7$ June 2007, by hand, woodland, M.G. Rix (WAM T94937); 1 ô, Kings Park, site KP 3/9, 31'58'15"S, 11549'20"E, 28 September 1993, dry pitfall trap, J. Dell (WAM T72791); 1 ô, Kings Park,
Lovekin Drive, 315' S, 11550'E, 25 March 1992, pitfall trap, burned/unlogged, R. Dixon and K. Keys (WAM T73123); 1 $\hat{~}$, Kings Park, Saw Avenue bike path, 31 $57^{\prime} 49.5^{\prime \prime} \mathrm{S}, 115^{\circ} 49^{\prime} 32.4^{\prime \prime} \mathrm{E}, 17$ June 2008, by hand, from bike path, J. M. Wojcieszek and M.G. Rix (WAM T130417); Kings Park, 31 ${ }^{\circ} 57^{\prime}$ S, 11550'E, May - June 1986, G. P. Hall (ANIC 1075); same details, September-October 1985 (ANIC 1050); same details, July - August 1985 (ANIC 1049); same details, July August 1985 (ANIC 1048); same details, July August 1985 (ANIC 1049); 1 §ै, Shannon State Forest, Mossop Road, c. 7 km W. of Mt Johnson, 3443'10"S, $116^{\circ} 31^{\prime} 02^{\prime \prime E}, 10$ July 2003, by hand, under logs, jarrah/karri forest on laterite, K. Edward and R. Teale (WAM T54836); 1 ð, 1 juvenile, Bungendore Park, Bedfordale, $32^{\circ} 10^{\prime} \mathrm{S}, 116^{\circ} 02^{\prime} \mathrm{E}, 17$ August 2003, jarrah forest, T.F. Houston et al. (WAM T55928); 2 웅, Helena Vale (Helena Valley), $31^{\circ} 55^{\prime} \mathrm{S}, 116^{\circ} 02^{\prime} \mathrm{E}, 1 \mathrm{July}$ 1925, O.H. Lipfert (WAM T56288, original number 25/491); 1 ㅇ, c. $15 \mathrm{~km} \mathrm{SE}$. of The Lakes, Yarra Road,

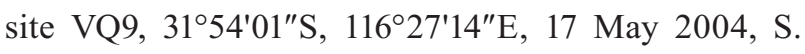
Slack-Smith, G.W. Kendrick and J. Dunlop (WAM T60310); 1 $\hat{\text {, }}$, Mundaring Shire, Horton Road, c. 4 km NE. of The Lakes, $31^{\circ} 52^{\prime} 05^{\prime \prime} \mathrm{S}, 116^{\circ} 20^{\prime} 35^{\prime \prime} \mathrm{E}, 28$ July 2002, jarrah regrowth, Allocasuarina frazeriana, S. Slack-Smith (WAM T72761); 1 ô, Wungong Dam, scree slope above trail to dam, $32^{\circ} 11^{\prime} 45^{\prime \prime} \mathrm{S}$, $116^{\circ} 03^{\prime} 37^{\prime \prime}$ E, 12 July 2004, under rocks, M.S. Harvey, J.M. Waldock, R. Engel and T. Moulds (WAM T62257); 1 ô, Wungong Dam, outside toilets at carpark, $32^{\circ} 12^{\prime} \mathrm{S}, 116^{\circ} 04^{\prime} \mathrm{E}, 12$ July 2004 , dead on ground outside toilet block, J.M. Waldock; F. Harvey and E. Harvey (WAM T62258); 1 ふै, Boddington Bauxite Mine, site NP98A, north pit 1998 rehabilitation, $32^{\circ} 55^{\prime} 39^{\prime \prime} \mathrm{S}, 116^{\circ} 26^{\prime} 35^{\prime \prime} \mathrm{E}$, October 2003, wet pitfall trap, G. Oraby (WAM T66376); 1 ऽ, same details, site NP86, north pit 1986 rehabilitation, $32^{\circ} 55^{\prime} 51^{\prime \prime} \mathrm{S}, 116^{\circ} 26^{\prime} 41^{\prime \prime} \mathrm{E}$, October 2003 (WAM T66377); 2 今, same details, site WP92, west pit 1992 rehabilitation, $32^{\circ} 56^{\prime} 01^{\prime \prime} \mathrm{S}, 116^{\circ} 25^{\prime} 56^{\prime \prime} \mathrm{E}$, October 2003 (WAM T66378); 1 juvenile, same details, site EP93, west pit 1993 rehabilitation, 32 ${ }^{\circ} 56^{\prime} 26^{\prime \prime} \mathrm{S}, 116^{\circ} 27^{\prime} 45^{\prime \prime} \mathrm{E}$, July 2003 (WAM T66379); 1 ô, same details, site MO2J, 32 $55^{\prime} 47^{\prime \prime} \mathrm{S}, 116^{\circ} 26^{\prime} 39^{\prime \prime} \mathrm{E}$, October 2003 (WAM

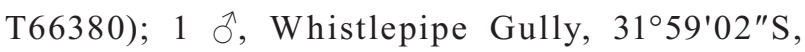
$116^{\circ} 02^{\prime} 17^{\prime \prime} \mathrm{E}, 24$ July 2005 , on ground, rainy day, M.S. Harvey and J.M. Waldock (WAM T66381); 1 ふ, 5 ㅇ, Wambyn Nature Reserve, site YO 11, wet pitfall trap, s 01, 02, 05, 07, 08, 31 $53^{\prime} 46^{\prime \prime} \mathrm{S}, 116^{\circ} 37^{\prime} 25^{\prime \prime} \mathrm{E}, 20$ May 1997 - 29 September 1998, wet pitfall trap, B. Durrant 
(WAM T72619); 6 Oे, 4 +,Wambyn Nature Reserve, site YO 10, wet pitfall trap, s 03, 05, 07, 09, $31^{\circ} 54^{\prime} 02^{\prime \prime} \mathrm{S}, 116^{\circ} 38^{\prime} 22^{\prime \prime} \mathrm{E}, 22$ May 1998 - 29 September 1998, wet pitfall trap, L. King (WAM T72620); 9 §, 3 \&, 1 juvenile, Quarry Rd, Bald Hill Lookout, site JB 2, wet pitfall trap, s 1-5, 31 35'13"S, 116¹5'57"E, 15 September 1998 - 4 November 1999, wet pitfall trap, P. Van Heurck (WAM T72621); 4 §ิ, Quarry Rd, Avon River North Bank, site JB 1, $31^{\circ} 34^{\prime} 46^{\prime \prime} \mathrm{S}, 116^{\circ} 15^{\prime} 48^{\prime \prime} \mathrm{E}, 15$ September 1998 - 4 November 1999, wet pitfall trap, P. Van Heurck (WAM T72622); 1 § , 1 q, Julimar Conservation Park, North, site JB 13, 31 $21^{\prime} 21^{\prime \prime} \mathrm{S}, 116^{\circ} 13^{\prime} 04^{\prime \prime} \mathrm{E}, 15$ September 1998 - 4 November 1999, wet pitfall trap, B. Durrant (WAM T72623); 2 ภ, 3 +, 1 juvenile, Julimar, Cooks Road, East, site JB 9, wet pitfall trap, s $1-5 \times 2,31^{\circ} 27^{\prime} 03^{\prime \prime} \mathrm{S}, 116^{\circ} 16^{\prime} 22^{\prime \prime} \mathrm{E}, 15$ September 1998 4 November 1999, wet pitfall trap, P. Van Heurck (WAM T72624); 1 ○, 1 q, Julimar Conservation Park,

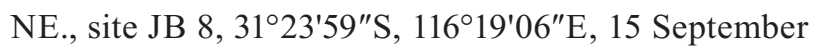
1998 - 4 November 1999, wet pitfall trap, B. Durrant (WAM T72625); 1 万, Julimar Conservation Park,

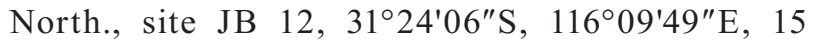
September 1998 - 4 November 1999, wet pitfall trap, N. Guthrie (WAM T72626); $1 \hat{\jmath}$, Attunga Road, Skeleton Block, Dryandra, site NR03, 32 46'58"S, 116 $51^{\prime} 54^{\prime \prime E}, 16$ September 1998, wet pitfall trap, L. King (WAM T72627); 1 , Wandering Road, East, site NR5, 32 ${ }^{\circ} 51^{\prime} 16^{\prime \prime} \mathrm{S}, 116^{\circ} 49^{\prime} 45^{\prime \prime} \mathrm{E}, 2$ June 1998 - 16 September 1998, wet pitfall trap, L. King (WAM T72628); 3 ภ, 2 क, Drummond Nature Reserve,

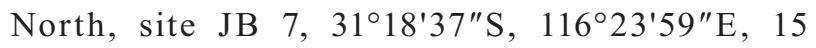
September 1998 - 4 November 1999, wet pitfall trap, P. Van Heurck (WAM T72629); 1 §, Catchment Road, site YO 05, wet pitfall trap, s 01, 03, 05, 06, 09, $32^{\circ} 05^{\prime} 43^{\prime \prime}$ S, 116³8'27"E, 26 May - 5 November1998, wet pitfall trap, P. van Heurck and N. Guthrie (WAM T72630); 2 ô, 1 juvenile, Boolading Nature Reserve,

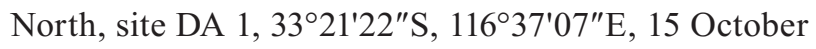
1999 - 1 November 2000, wet pitfall trap, P. Van Heurck et al. (WAM T72631); 1 §, 5 juveniles, Hillman Nature Reserve, NNE. of Darkin, site DA 11, wet pitfall trap, s $5+5,33^{\circ} 17^{\prime} 53^{\prime \prime} \mathrm{S}, 116^{\circ} 46^{\prime} 19^{\prime \prime} \mathrm{E}, 15$ October - 2 December 2000, wet pitfall trap, P. Van Heurck et al. (WAM T72632); $1 \hat{\delta}, 10$ Mile Hill, site

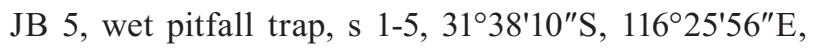
15 September 1998 - 4 November 1999, wet pitfall trap, L. King (WAM T72633); 1 § , St Ronans Nature

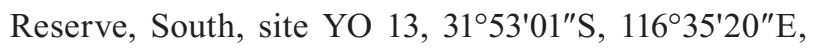
26 May 1998 - 29 November 1998, wet pitfall trap, P. Van Heurck (WAM T72634); $1 \hat{\delta}, 1$, St Ronans Nature Reserve, North, site YO 12, 31 ${ }^{\circ} 52^{\prime} 30^{\prime \prime} \mathrm{S}$, 116³6'10"E, 26 May 1998 - 29 November 1998, wet pitfall trap, P. Van Heurck (WAM T72635); 1 गै, Parmelia, 15 Sicklemore Road, 32 ${ }^{\circ} 14^{\prime} \mathrm{S}, 115^{\circ} 50^{\prime} \mathrm{E}, 26$ June 2003, A. E. de Jong (WAM T72636); 1 §, same details, 1 August 2002 (WAM T72637); 1 ô, same details, 9 July 1996 (WAM 73111); 1 क, 1 juvenile, near Jarrahdale, $32^{\circ} 17^{\prime} 19^{\prime \prime} \mathrm{S}, 116^{\circ} 06^{\prime} 04^{\prime \prime} \mathrm{E}, 2$ June 2001, by hand, E. S. Volschenk (WAM T72638, T72639); 1 $\hat{0}$, near Jarrahdale, $32^{\circ} 17^{\prime} 42^{\prime \prime} \mathrm{S}, 116^{\circ} 08^{\prime} 18^{\prime \prime} \mathrm{E}, 2$ June 2001, by hand, E. S. Volschenk (WAM T72640); 2 ㅇ, near Jarrahdale, $32^{\circ} 17^{\prime} 35^{\prime \prime} \mathrm{S}, 116^{\circ} 10^{\prime} 40^{\prime \prime} \mathrm{E}, 2$ June 2001, by hand, E. S. Volschenk (WAM T72641); 1 ㅇ, Jarrahdale Mine Area, site $94 \mathrm{~F} 4 \mathrm{~d} 3,32^{\circ} 16^{\prime} 01.8^{\prime \prime} \mathrm{S}$, $116^{\circ} 04^{\prime} 10^{\prime \prime} \mathrm{E}$, April 1998, pitfall trap, L. Ashby (WAM T72642); 1 ㅇ, Jarrahdale Mine Area, site 94F4a6, $32^{\circ} 16^{\prime} 01.8^{\prime \prime} \mathrm{S}, 116^{\circ} 04^{\prime} 10^{\prime \prime} \mathrm{E}$, April 1998, pitfall trap, L. Ashby (WAM T72643); 1 juvenile, Jarrahdale Mine Area, site $91 \mathrm{~F} 3 \mathrm{c} 5,32^{\circ} 17^{\prime} 35^{\prime \prime} \mathrm{S}, 116^{\circ} 10^{\prime} 39.8^{\prime \prime} \mathrm{E}$, April 1998, pitfall trap, L. Ashby (WAM T72644); 1 q, Jarrahdale Mine, $32^{\circ} 14^{\prime} \mathrm{S}, 116^{\circ} 06^{\prime} \mathrm{E}$, .VI.1997, October 1997, pitfall trap, K.E.C. Brennan (WAM T72645); 4 $\hat{~}, 1$ ㅇ, 5 juveniles, $1 \mathrm{~km}$ SE. of Jarrahdale, Mundlinup State Forest, $32^{\circ} 22^{\prime} 22.3^{\prime \prime} \mathrm{S}, 116^{\circ} 04^{\prime} 30.6^{\prime \prime} \mathrm{E}$, 15 July 2012, by hand, fallen logs, C.A. Car and N.G. Car (WAM T126045); 1 ô, Lane Pool Reserve, $32^{\circ} 47^{\prime} \mathrm{S}, 11^{\circ} 04^{\prime} \mathrm{E}, 15$ August 1987, O. Mueller (WAM T72757); 1 §, Lane Poole Reserve, adjacent to Nanga Rd.32²7'29.2"S, $116^{\circ} 05^{\prime} 20.2^{\prime \prime E}, 13$ July 2008, by hand, from leaf litter, J. M. Wojcieszek and M.G. Rix (WAM T130419); 3 ग, 2 ㅇ, 1 juvenile, Mount Cooke, $32^{\circ} 24^{\prime} \mathrm{S}, 116^{\circ} 18^{\prime} \mathrm{E}, 31$ March 1968 , collected with Urodacus novaehollandiae and U. planimanus, E.G. Cockett (WAM T72759); 1 $\partial^{2}$, Mount Cooke, 32 $25^{\circ} \mathrm{S}$, 116 ${ }^{\circ} 18^{\prime}$ E, 31 July 1991-19 September 1991, hand collected, M.S. Harvey and J.M. Waldock (WAM T73117); 1 +, same details, pitfall traps site 1 (WAM T73118); 2 + 1 juvenile, same details, pitfall traps site 3, 24 April - 15 May 1991 (WAM T73119); 2 đે, 2 ㅇ, 1 juvenile, Mt Cooke, near summit, $32^{\circ} 25^{\prime} \mathrm{S}, 116^{\circ} 18^{\prime} \mathrm{E}, 7$ August 1990, M.S. Harvey, J.M. Waldock and M. Peterson (WAM T73120); 2 ô, 2 क, Mount Cooke, $32^{\circ} 25^{\prime}$ S, $116^{\circ} 18^{\prime} \mathrm{E}, 19$ September 1991, J.M. Waldock

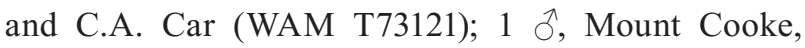
$32^{\circ} 24^{\prime}$ S, $116^{\circ} 18^{\prime}$ E, 20 July 2002 , M.S. Harvey, M.G. Rix and M.E. Blosfelds (WAM T73358); 4 đ, 1 q, same details, 30 July 2002 (WAM T112669, T112670); 1 ठै, Mt Cooke, SW. of slopes, $32^{\circ} 25^{\prime} \mathrm{S}, 116^{\circ} 18^{\prime} \mathrm{E}, 29$ July 2000, by hand, under granite slabs, J.M. Waldock and S. Slack-Smith (WAM T73403); 1 ô, Tenilba

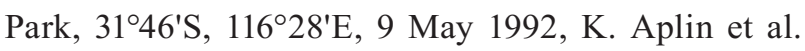
(WAM T72760); 1 $\hat{\jmath}$, Ridge Hill Road, Bushmead, site BM2, 31'55'56"S, 116 02'22"E, 21 August 1996, hand collecting, M.S. Harvey(WAM T72762); 1 , Topher/Darkin Roads junction, c. 2 km SW. of Darkin 
Swamp, $32^{\circ} 05^{\prime}$ S, $116^{\circ} 23^{\prime} \mathrm{E}, 2$ October 1995, J.M. Waldock (WAM T72763); 1 †, base of Mt Dale, W. side, $32^{\circ} 08^{\prime} \mathrm{S}, 116^{\circ} 18^{\prime} \mathrm{E}, 27$ September 1998 , by hand, J.M. Waldock et al. (WAM T72764), 1 \&, S. base of Mt Dale, $32^{\circ} 08^{\prime} \mathrm{S}, 116^{\circ} 18^{\prime} \mathrm{E}, 30$ September 1991 , by hand, J.M. Waldock (WAM T73126); 1 ô, c. $13 \mathrm{~km}$ SE. of Mt Dale, near water point on Running Brook $\mathrm{Rd}, 32^{\circ} 12^{\prime} \mathrm{S}, 116^{\circ} 25^{\prime} \mathrm{E}, 27$ September 1999, by hand, found dead, J.M. Waldock (WAM T73127); 1 q, granite outcrop along S. edge of Beraking Brook, Smith Rd, c. $6.5 \mathrm{~km} \mathrm{SE}$. of Mt Dale, $32^{\circ} 08^{\prime} \mathrm{S}$, $116^{\circ} 21^{\prime} \mathrm{E}, 26$ September 1999, by hand, found dead on

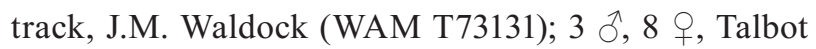
Road Reserve, site TR1, 31 ${ }^{\circ} 52^{\prime} 05^{\prime \prime} \mathrm{S}, 116^{\circ} 03^{\prime} 04^{\prime \prime} \mathrm{E}, 28$ July - 23 September 1993, wet pitfall trap, J.M. Waldock, et al. (WAM T72758); 2 ภ, 2 +, 1 juvenile, same locality, 24-29 August 1993, dry pitfall trap, J. Dell (WAM T72771); 1 ${ }^{\lambda}$, Talbot Road Reserve, site TR2, 31 ${ }^{\circ} 52^{\prime} 25^{\prime \prime} \mathrm{S}, 116^{\circ} 03^{\prime} 03^{\prime \prime} \mathrm{E}, 28$ July - 23 September 1993, wet pitfall trap, J.M. Waldock, A. Sampey and A. Thorpe (WAM T72769); 1 đ, same locality, 24 June - 28 July 1993, wet pitfall trap, M.S. Harvey and J.M. Waldock (WAM T72770); 1 Ô, 2 juveniles, Talbot Road Reserve, site TR4, 31 52 '23"S, $116^{\circ} 02^{\prime} 46^{\prime \prime}$ E, 24 June - 28 July 1993, wet pitfall trap, M.S. Harvey and J.M. Waldock (WAM T72772); 1 ๙ Wexcombe, W. side of Talbot Road, outside NE. corner of Reserve, $31^{\circ} 52^{\prime} \mathrm{S}, 116^{\circ} 03^{\prime} \mathrm{E}, 10$ May -24 June 1993, wet pitfall trap, M.S. Harvey and J.M. Waldock (WAM T72793); 2 ภ, 2 ㅇ, Talbot Road Reserve, SE. section, site POI190, 31 $52^{\prime} 24^{\prime \prime} \mathrm{S}$, $116^{\circ} 02^{\prime} 54^{\prime \prime}$ E, 28 July 2002, M.S. Harvey and J.M. Waldock (WAM T97959-63); 1 juvenile, same locality, site POI $189,31^{\circ} 52^{\prime} 21^{\prime \prime} \mathrm{S}, 116^{\circ} 02^{\prime} 52^{\prime \prime} \mathrm{E}, 28$ July 2002, M.S. Harvey and J.M. Waldock (WAM T97964); 1 Oे, Talbot Road Reserve, Stratton, Perth, $31^{\circ} 52^{\prime} 04^{\prime \prime} \mathrm{S}, 116^{\circ} 03^{\prime} 02^{\prime \prime} \mathrm{E}, 31$ May 2007, by hand, M.G. Rix (WAM T94936); 1 $\hat{\text {, }}$, Wandoo National Park, off Talbot West Rd, 31 $58^{\prime} 34.7^{\prime \prime} \mathrm{S}, 116^{\circ} 32^{\prime} 50.9^{\prime \prime} \mathrm{E}, 1$ September 2008, by hand, from leaf litter, J.M. Wojcieszek and M.G. Rix (WAM T130421); 1 ㅇ, Rushton Road Reserve, Martin, site RR2, 32 $03^{\prime} 54^{\prime \prime}$, $116^{\circ} 01^{\prime} 03^{\prime \prime} \mathrm{E}, 5$ May 1997, hand collecting, underneath pitfall trap, J.M. Waldock (WAM T72773); $1 \hat{\jmath}$, same locality, 16 April - 17 June 1996, wet pitfall trap, J.M. Waldock, P. West and A.F. Longbottom (WAM T72778); 2 \&, Rushton Road Reserve, Martin, site RR1, 32 $03^{\prime} 50^{\prime \prime} \mathrm{S}, 116^{\circ} 01^{\prime} 08^{\prime \prime} \mathrm{E}, 16$ April - 17 June 1996, wet pitfall trap, J.M. Waldock, P. West and A.F. Longbottom (WAM T72779); $1 \hat{\jmath}, 1$ q, Martin, 20 Milleara Road, $32^{\circ} 05^{\prime} 10^{\prime \prime} \mathrm{S}, 116^{\circ} 01^{\prime} 28^{\prime \prime} \mathrm{E}, 15$ June 2010, under rock, M.L. Moir (WAM T 119344); 1 §, Perth Airport, site PA8, 31 $58^{\prime} 36^{\prime \prime} \mathrm{S}, 115^{\circ} 58^{\prime} 28^{\prime \prime} \mathrm{E}, 24$
September - 18 November 1993, wet pitfall trap, J.M. Waldock, et al. (WAM T72780); 1 ô, Perth Airport, site PA6, 31 ${ }^{\circ} 58^{\prime} 05^{\prime \prime} \mathrm{S}, 115^{\circ} 58^{\prime} 05^{\prime \prime} \mathrm{E}, 28$ July - 23 September 1993, wet pitfall trap, J.M. Waldock, et al. (WAM T72781); 1 $0^{7}$, Perth Airport, site PA7, $31^{\circ} 58^{\prime} 34^{\prime \prime}$ S, $115^{\circ} 58^{\prime} 25^{\prime \prime} \mathrm{E}, 24-29$ August 1993, dry pitfall trap, J. Dell (WAM T72646); 1 $\hat{\text {, }}$, same locality, 10 May - 24 June 1993, wet pitfall trap, J.M. Waldock, et al. (WAM T72782); 2 §, 1 ๆ, 2 juveniles, same locality, 28 July - 23 September 1993, wet pitfall trap, J.M. Waldock, et al. (WAM T72783, T72784); 1 ${ }^{\circ}$, Perth Airport, site PA8, 31 ${ }^{\circ} 58^{\prime} 36^{\prime \prime} \mathrm{S}, 115^{\circ} 58^{\prime} 28^{\prime \prime} \mathrm{E}$, 24-29 August 1993, dry pitfall trap, J. Dell (WAM T72785); 1 ㅇ, same locality, 18-31 October 1993, dry pitfall trap, J. Dell (WAM T72786); 1 ô, 1 juvenile, same locality, 28 July - 23 September 1993, wet pitfall trap, J.M. Waldock (WAM T72787); 2 ô, Perth Airport, NE. side of International runway, $31^{\circ} 56^{\prime} \mathrm{S}$, $115^{\circ} 58^{\prime} \mathrm{E}$, 26 June 1987, banksia woodland on sand, J. Dell (WAM T73114); 2 ô, Marangaroo Reserve, site MR2, 31 49'38"S, 11550'04"E, 1-15 October 1995, dry pitfall trap, J. Dell (WAM T72792); 1 , Hartfield Park, Forrestfield, site HF1, 32 $00^{\prime} 00^{\prime \prime} \mathrm{S}, 115^{\circ} 59^{\prime} 43^{\prime \prime} \mathrm{E}$, 5 May 1997, J.M. Waldock (WAM T72794); 1 đૈ, Worsley Alumina Project, Mt Saddleback area, trap 1, $32^{\circ} 58^{\prime} \mathrm{S}, 116^{\circ} 27^{\prime} \mathrm{E}$, July 1980 , by hand, under log, D. Halford and M. Sawle (WAM T72850); 1 ð, 1 क, same locality, Tunnell Road, July 1980, small pitfall trap, D. Halford and M. Sawle (WAM T72851); 1 juvenile, same locality, Tunnell Road, 17 July 1980, by hand, in litter, wandoo, D. Halford and M. Sawle (WAM T72855); 1 ㅇ, same locality, PIL H, 28 October 1980, pitfall trap, D. Halford and M. Sawle (WAM T72852); 1 , same locality, trap 3, 3 July 1980, by hand, under log, D. Halford and M. Sawle (WAM T72853); 2 ภ, same locality, TL 9, Forty Hollow Road, July 1980, large pitfall trap, D. Halford and M. Sawle (WAM T72854); 1 juvenile, same locality, PIL G, 28 October 1980, pitfall trap, D. Halford and M. Sawle (WAM T72856); 2 ô, same locality, trapline 7, 19 July 1980, by hand, under logs, jarrah, D. Halford and M. Sawle (WAM T72857); 1 O, 1 क , SW. of Boddington, Worsley Alumina, Overland conveyor belt, HarveyQuindaning Road, transfer point, $33^{\circ} 03^{\prime} \mathrm{S}, 116^{\circ} 09^{\prime} \mathrm{E}$, 18 June 2006, night shift, J. Hynes (WAM T77050); 1 , Worsley Alumina, Overland conveyor belt \#1, line stand $4425,33^{\circ} 00^{\prime} \mathrm{S}, 116^{\circ} 16^{\prime} \mathrm{E}$, 9 July 2006 , night shift, J. Hynes (WAM T77051); 3 ${ }^{\lambda}, 1$ juvenile, same locality, line stand 116 to $850,32^{\circ} 58^{\prime} \mathrm{S}, 116^{\circ} 21^{\prime} \mathrm{E}, 7$ July 2006, night shift, J. Hynes (WAM T77961); 1 गै, same locality, line stand $242,32^{\circ} 59^{\prime} \mathrm{S}, 116^{\circ} 20^{\prime} \mathrm{E}, 22$ May 2006, night shift, J. Hynes (WAM T77962); 1 đ, Worsley Alumina Overland Conveyor Belt, SW. of 
Boddington, conveyor \#2, 3304'15"S, 116 09'25"E, 8 June 2007, by hand, night shift, J. Hynes (WAM T87169); 1 ઈ, 3 juveniles, same locality, conveyor \#1, $32^{\circ} 56^{\prime} 39^{\prime \prime} \mathrm{S}, 116^{\circ} 26^{\prime} 51^{\prime \prime} \mathrm{E}, 3$ June 2007 , by hand, night shift, J. Hynes (WAM T87170); $1 \curvearrowright 16.3 \mathrm{~km} \mathrm{~W}$. of Quindanning, Worsley Alumina conveyor \#1, 32 57'04"S, 116 25'49"E, 31 July 2009, at night, J. Hynes (WAM T99497); 1 ふै, W. of Boddington, Worsley Alumina Overland Conveyor Belt, conveyor \#2, line stand $8431,33^{\circ} 12^{\prime} \mathrm{S}, 116^{\circ} 04^{\prime} \mathrm{E}, 26$ July 2006 , night shift, J. Hynes (WAM T99955); 1 $\hat{\text {, }}$ SW. of Boddington, Worsley Alumina, Overland Conveyor Belt \#1, line stand 116 to $850,32^{\circ} 58^{\prime} \mathrm{S}, 116^{\circ} 21^{\prime} \mathrm{E}, 7$

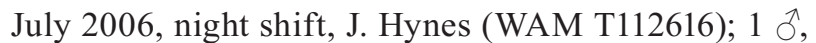
Boddington Bauxite Mine, site MO2J, 32 55'47"S, $116^{\circ} 26^{\prime} 39^{\prime \prime} \mathrm{E}$, April 2003, wet pitfall trap, G. Oraby (WAM T73262); $4 \hat{\jmath}$, Boddington Bauxite Mine, site EP86, east pit, 1986 rehabilitation, $32^{\circ} 56^{\prime} \mathrm{S}, 116^{\circ} 28^{\prime} \mathrm{E}$, July 2003, wet pitfall trap, G. Oraby (WAM T73263); 1 ô, Gosnells Quarry, 32 $05^{\prime} \mathrm{S}, 116^{\circ} 00^{\prime} \mathrm{E}, 24$ July 1988, by hand, J.M. Waldock (WAM T73112); 1 , Roleystone, 110 Brookton Highway, $32^{\circ} 07^{\prime} \mathrm{S}$, 11604'E, 22 June 1997, T. McNamara (WAM T73113); 3 ภ, 5 ㅇ, Walyunga National Park, 314' $\mathrm{S}$, $116^{\circ} 04^{\prime} \mathrm{E}, 4$ May 1989, M. Archer and E. Jefferys (WAM T73115); 1 §̊, 4 9, 6 km SW. of Gidgegannup, $31^{\circ} 20^{\prime} \mathrm{S}, 116^{\circ} 08^{\prime} \mathrm{E}, 6$ May 1989 , by hand, W.A. Arachnology Group (WAM T73116); 1ð̄, Avon Valley, $31^{\circ} 37^{\prime} \mathrm{S}, 116^{\circ} 12^{\prime} \mathrm{E}$, June 1997, F. Turnbull (WAM T73122); 1 đ̊, Salter Point, $32^{\circ} 01^{\prime} \mathrm{S}, 115^{\circ} 52^{\prime} \mathrm{E}, 18$ June 1979, L.E. Koch (WAM T73125); 1 ふै, Serpentine National Park, Serpentine Falls, northern hillside, $32^{\circ} 22^{\prime} \mathrm{S}, 116^{\circ} 00^{\prime} \mathrm{E}, 27$ July 1969, by hand, G.W. Kendrick and S.M. Slack-Smith (WAM T73128); 1 ๙, Serpentine Falls National Park, uphill from Falls Rd car park, 32²2'01"S, $116^{\circ} 00^{\prime} 28^{\prime \prime} \mathrm{E}, 13$ May 2007, by hand, from leaf litter, J. M. Wojcieszek and M.G. Rix (WAM T 130423); 1 ô, Serpentine National Park, Serpentine Falls, northern hillside, $32^{\circ} 22^{\prime} \mathrm{S}, 116^{\circ} 00^{\prime} \mathrm{E}$, 6 August 2005, M.S. Harvey, C. Buddle, F. Harvey and E. Harvey (WAM T76136); 2 , , Serpentine Falls National Park, $32^{\circ} 22^{\prime} 01^{\prime \prime S}, 116^{\circ} 00^{\prime} 28^{\prime \prime}$ E, 16 May 2007 , by hand, open jarrah forest, J.M. Wojcieszek and M.G. Rix (WAM T102750, T102751); 1 ô, same locality, 9 June 2007, by hand, open jarrah forest, J.M. Wojcieszek and M.G. Rix (WAM T102752); $1 \hat{\jmath}$, Hovea, 315' S, $116^{\circ} 06^{\prime} \mathrm{E}, 21$ June 1993, A. Sampey (WAM T73129); 1 §,, Blackboy Ridge, Chittering Road, SW. of Bindoon, 22 June 1997, by hand, on grass, J.M. Waldock (WAM T73130); 1 तै, Sullivan Rock, $19.6 \mathrm{~km} \mathrm{~N}$. of North Bannister, 32²4'S, $116^{\circ} 27^{\prime} \mathrm{E}, 9$ July 1978, by hand, M. Colreavy (WAM T73132); 1 đ̂, 2 juveniles, Logue Brook Dam Road, $33^{\circ} 00^{\prime} \mathrm{S}, 115^{\circ} 59^{\prime} \mathrm{E}, 31$ August 2005, under granite, P.J. Mann (WAM T73265); 1 ๙ै, Wandering Shire, 3241'S, 116 40'E, 24 August 1969, by hand, D.S. Adair (WAM T73392); 1 ふै, Red Hill, Toodyay Road, Hanson's Quarry Site, $31^{\circ} 50^{\prime} \mathrm{S}, 116^{\circ} 05^{\prime} \mathrm{E}, 16$ May 2007 , amongst granite boulders, M. Bamford and I. Harris (WAM T82716); 1 , Toodyay Road, Boral Gidgegannup Quarry, 31 $49^{\prime} 38.1^{\prime \prime} \mathrm{S}, 116^{\circ} 05^{\prime} 36.2^{\prime \prime} \mathrm{E}, 27$ September 2007, under granite, M. Bamford and W. Bancroft (WAM T82717); 4 ô, W. of Collie, Arklow/Scar Road, 3316'12.61"S, 116 06'02.99"E, 21 - 27 May 2007, W. Bancroft (WAM T83391); 1 o, 1 ㅇ, Centaur Road, c.

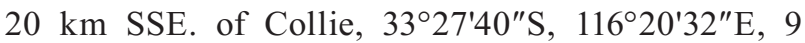
September 2008, part cleared near wetland, M.J. Bamford et al. (WAM T92447); $1 \hat{\jmath}$, Westralia Conservation Park, west of Collie, $33^{\circ} 20^{\prime} 41^{\prime \prime} \mathrm{S}$, 116 06'29"E, 27 April 2008, by hand, from leaf litter, J. M. Wojcieszek and M.G. Rix (WAM T130418); 7 §ै, 5 q, Pearce Airforce Base, 31 ${ }^{\circ} 29^{\prime} 14.10^{\prime \prime} \mathrm{S}$, $116^{\circ} 06^{\prime} 57.72^{\prime \prime} \mathrm{E}, 23$ June -8 August 2008, wet pitfall trap, J. Nolthenous and F. Bochari (WAM T108475); 10 ô, 4 q, 5 juveniles, Pearce Airforce Base, $31^{\circ} 31^{\prime} 18.36^{\prime \prime} \mathrm{S}, 116^{\circ} 01^{\prime} 32.40^{\prime \prime} \mathrm{E}, 23$ June -8 August 2008, wet pitfall trap, J. Nolthenous and F. Bochari (WAM T108914, T109216); 7 ふ̂, 3 q, 3 juveniles, Pearce Airforce Base, $31^{\circ} 31^{\prime} 14.64^{\prime \prime} \mathrm{S}, 116^{\circ} 01^{\prime} 49.32^{\prime \prime} \mathrm{E}$, 23 June -8 August .2008, wet pitfall trap, J. Nolthenous and F. Bochari(WAM T109217); 1 ô, Mirrabooka, $31^{\circ} 51^{\prime} 35^{\prime \prime} \mathrm{S}, 115^{\circ} 51^{\prime} 43^{\prime \prime} \mathrm{E}, 13$ July 2010, hand collecting, C.A. Car (WAM T111730); 1 ô, Waterman, Star Swamp, 31 50'58"S, 11545'47"E, 2 October 2010, C.A. Car (WAM T111731); 2 ふ, Bibra Lake, Kwinana Freeway S. of Roe Highway intersection, $32^{\circ} 05^{\prime} 18.80^{\prime \prime} \mathrm{S}, 115^{\circ} 51^{\prime} 14.78^{\prime \prime} \mathrm{E}, 19-25$ September 2010, foraging, J. Clark (WAM T112293); 2 individuals, Bibra Lake, NE. of Bibra Lake at Bibra $\mathrm{Rd}, 32^{\circ} 05^{\prime} 37.05^{\prime \prime} \mathrm{S}, 115^{\circ} 49^{\prime} 11.47^{\prime \prime} \mathrm{E}, 18-24$ July 2010, dry pitfall trap, J. Clark (WAM T112294); 3 individuals, same locality, 19-25 September 2010, foraging, J. Clark (WAM T112299); 1 ふै, same locality, 11-17 August 2010, dry pitfall trap, J. Clark (WAM T112305); 1 \&, same locality, 17-22 May 2010, dry pitfall trap, J. Clark (WAM T112307); 3 individuals, Bibra Lake between Hope $\mathrm{Rd}$ and Farrington Rd, $32^{\circ} 04^{\prime} 53.67^{\prime \prime} \mathrm{S}, 115^{\circ} 50^{\prime} 07.61^{\prime \prime} \mathrm{E}, 19-25$ September 2010, foraging, J. Clark (WAM T112295, T112300); 2 त̂, same locality, 15-20 February 2010, dry pitfall trap, J. Clark (WAM T112301); 2 individuals, Bibra Lake, E. of North Lake (Farrington $\mathrm{Rd}$ ), 3204'35.56"S, 11549'47.28"E, 11-17 August 2010, dry pitfall trap, J. Clark (WAM T112296); 2 ㅇ, same locality, 18-24 July 2010, dry pitfall trap, J. Clark (WAM T112310); 5 ふ̄, 1 오 , Bibra Lake, N. of 
Hope Rd, 3205'04.32"S, 11549'49.55"E, 18-24 July 2010, dry pitfall trap, J. Clark (WAM T112297); 1 juvenile, Bibra Lake, Kwinana Freeway, S. of Roe Highway intersection, $32^{\circ} 05^{\prime} 18.80^{\prime \prime} \mathrm{S}, 115^{\circ} 51^{\prime} 14.78^{\prime \prime} \mathrm{E}$, 11-17 August 2010, dry pitfall trap, J. Clark (WAM T112303); 7 Oै, 3 क , same locality, 29 March - 4 May 2010, dry pitfall trap, J. Clark (WAM T112309); 1 ô,1 ㅇ, Bibra Lake, W. side, N. of Gwilliam Drive, $32^{\circ} 05^{\prime} 25.48^{\prime \prime}$ S, $115^{\circ} 49^{\prime} 09.65^{\prime \prime}$ E, 18-24 July 2010, dry pitfall trap, J. Clark (WAM T112311, T112312); 6 đ, 1 + , Beeliar Regional Park, NE. of South Lake, $32^{\circ} 05^{\prime} 14.24^{\prime \prime}$ S, $115^{\circ} 47^{\prime} 57.23^{\prime \prime} \mathrm{E}, 18-24$ July 2010 , dry pitfall trap, J. Clark (WAM T112308); 1 ठै, Bibra Lake Bushland, Beeliar Wetlands, north-west of Bibra Lake, $33^{\circ} 17^{\prime} 23^{\prime \prime} \mathrm{S}, 116^{\circ} 05^{\prime} 36^{\prime \prime} \mathrm{E}$, 11 June 2008 , by hand, from leaf litter, J. M. Wojcieszek and M.G. Rix (WAM T130424); 4 ふ̊, 3 9, Coolbellup, Stock Rd @ Forrest Rd intersection, $32^{\circ} 05^{\prime} 14.24 " \mathrm{~S}$, $115^{\circ} 47^{\prime} 57.23^{\prime \prime} \mathrm{E}, 17-22$ May 2010, dry pitfall trap, J. Clark(WAM T112298); 1 ô, 2 ค, 4 juveniles, same locality, 11-17 August 2010, dry pitfall trap, J. Clark (WAM T112304); 3 đ, 1 +, Coolbellup, Stock Rd @ Forrest Rd intersection, 32 ${ }^{\circ} 06^{\prime} 12.66^{\prime \prime} \mathrm{S}$, $115^{\circ} 48^{\prime} 51.45^{\prime \prime} \mathrm{E}, 11-17$ August 2010, dry pitfall trap, J. Clark (WAM T112306); 1 $\hat{\text {, }}$, Lesmurdie, Mundy Regional Park, near Lions Lookout, 32 $00^{\prime} 52^{\prime \prime} \mathrm{S}$, $116^{\circ} 02^{\prime} 06^{\prime \prime} \mathrm{E}, 28$ August 2010, C.A. Car (WAM T112866); 1 +, $6 \mathrm{~km} \mathrm{SW}$. of Gidgegannup, $31^{\circ} 20^{\prime} \mathrm{S}$, $116^{\circ} 08^{\prime} \mathrm{E}, 6$ May 1989, by hand, W.A. Arachnology Group (WAM T112927); 1 ㅇ, Mundaring, 31 ${ }^{\circ} 54^{\prime} \mathrm{S}$, $116^{\circ} 10^{\prime} \mathrm{E}, 15$ August 1912, W. B. Alexander (WAM T221, original number 12/5148); 1 o, rock pools on Helena River, c. $4 \mathrm{~km} \mathrm{~W}$. of Mundaring Weir, $31^{\circ} 57^{\prime} \mathrm{S}$, $116^{\circ} 09^{\prime}$ E, 19 June 1999, J.M. Waldock and A. Sampey (WAM T73124); 1 §, 1 + , Mundaring State Forest, off Mundaring Weir Road, $31^{\circ} 58^{\prime} \mathrm{S}, 116^{\circ} 07^{\prime} \mathrm{E}, 16$ August 2008, hand collected, leaf litter, J. M. Wojcieszek and M.G. Rix (WAM T115244); 1 ○, 1 +, Mundaring State Forest, off Mundaring Weir Road, 31 ${ }^{\circ} 58^{\prime} 16^{\prime \prime} \mathrm{S}$, $116^{\circ} 06^{\prime} 27^{\prime \prime} \mathrm{E}, 29$ May 2008, by hand, leaf litter, J. M. Wojcieszek and M.G. Rix (WAM T118988, T118990); 1 क, Mundaring State Forest, off Mundaring Weir Road, $31^{\circ} 58^{\prime} 03^{\prime \prime} \mathrm{S}, 116^{\circ} 07^{\prime} 08^{\prime \prime} \mathrm{E}, 16$ August 2008, by hand, leaf litter, J. M. Wojcieszek and M.G. Rix (WAM T118989); 1 $\hat{\delta}$, Marradong forest block, N. of Marradong, 32 $49^{\prime} 52.00^{\prime \prime} \mathrm{S}, 116^{\circ} 25^{\prime} 50.64^{\prime \prime} \mathrm{E}, 17$ October 2011, wet pitfall trap, plain, P.R. Langlands (WAM T117881); 1 ठ, same locality, 17 October 2011, foraging, plain, P.R. Langlands (WAM T117913: 2 $\widehat{\text {, }}$ 1 ㅇ, 1 juvenile, same locality, 7 September 2011, foraging, plain, P.R. Langlands (WAM T117890, T117894); 6 ภ, 1 O , 1 juvenile, same locality, 17 October 2011, wet pitfall trap, plain, P.R. Langlands
(WAM T117897, T117900, T117906); 2 §, 3 juveniles, Marradong forest block, NW. of Marradong, 3249'12.24"S, 116 24'56.31"E, 7 September 2011, foraging, swale, P.R. Langlands (WAM T117884); 1 , 1 q, 2 juveniles, same locality, 17 October 2011, wet pitfall trap, swale, P.R. Langlands (WAM T117885, T117899); 1 Ô, same locality, 7 September 2011, foraging, swale, P.R. Langlands (WAM T117901); 2 , same locality, 7 September 2011, litter sifting, swale, P.R. Langlands (WAM T117903); 1 ㅇ, same locality, 17 October 2011, foraging, swale, P.R. Langlands (WAM T117905); 1 đ̃, same locality, 17 October 2011, wet pitfall trap, swale, P.R. Langlands (WAM T117911); 5 §ै, Mooradung Nature Reserve, 32 $53^{\prime} 55.64^{\prime \prime} \mathrm{S}, 116^{\circ} 33^{\prime} 32.19^{\prime \prime} \mathrm{E}, 18$ October 2011, wet pitfall trap, undulating plain, P.R. Langlands (WAM T117882, T117896, T117908); 1 juvenile, same locality, 18 October 2011, foraging, undulating plain, P.R. Langlands (WAM T117891); 1 , Forest block, N. of Mount Saddleback, 3255'58.94"S, 116 $26^{\circ} 41.91^{\prime \prime}$ E, 6 September 2011, foraging, swale, P.R. Langlands (WAM T117886); 2 §, 2 ㅇ, same locality, 17 October 2011, wet pitfall trap, swale, P.R. Langlands (WAM T117887, T117893); 1 Oे, same locality, 17 October 2011, foraging, swale, P.R. Langlands (WAM T117898); 1 Oै, 1 क, same locality, 6 September 2011, foraging, swale, P.R. Langlands (WAM T117892, T117907); 1 juvenile, Forest block, N. of Mount Saddleback, 3255'58.94"S, $116^{\circ} 26^{\prime} 41.91^{\prime \prime} \mathrm{E}, 6$ September 2011, litter sifting, swale, P.R. Langlands (WAM T117910); 1 ô, 1 क, Forest block, NNW. of Mount Saddleback, 32 ${ }^{\circ} 54^{\prime} 29.49^{\prime \prime}$ S, $116^{\circ} 25^{\prime} 9.04^{\prime \prime}$ E, 17 October 2011, wet pitfall trap, mid-slope, P.R. Langlands (WAM T117914); 1 ㅇ, George block, WNW. of Mount Saddleback, 32 53'51.77"S, $16^{\circ} 22^{\prime} 29.79^{\prime \prime} \mathrm{E}, 8$ September 2011, foraging, plain, P.R. Langlands (WAM T117889); 1 juvenile, same locality, 18 October 2011, wet pitfall trap, plain, P.R. Langlands (WAM T117912); 1 $\widehat{O}, 1$ juvenile, Forest block, SE. of Mount Saddleback, 32 58'4.94"S, $116^{\circ} 27^{\prime} 17.62^{\prime \prime} \mathrm{E}, 17$ October 2011, foraging, mid-slope, P.R. Langlands (WAM T117904, T117909); 1 §, same locality, 17 October 2011, wet pitfall trap, mid-slope, P.R. Langlands (WAM T117915); 1 §, Forest block, N. of Quindanning, 32 $59^{\circ} 30.59^{\prime \prime} \mathrm{S}, 116^{\circ} 33^{\prime} 29.18^{\prime \prime} \mathrm{E}, 18$ October 2011, wet pitfall trap, swale, P.R. Langlands (WAM T117895); 1 o, Forest block, NNW. of Quindanning, $32^{\circ} 58^{\prime} 18.34^{\prime \prime} \mathrm{S}, 116^{\circ} 30^{\prime} 52.76^{\prime \prime} \mathrm{E}, 8$ September 2011, foraging, swale, P.R. Langlands (WAM T117902); 2 오 , same locality, 32 $45^{\prime} 58.5^{\prime \prime} \mathrm{S}$, $116^{\circ} 23^{\prime} 33.2^{\prime \prime} \mathrm{E}, 18$ August 2011, hand collection, wandoo woodland, A. Rakimov (WAM T119587,

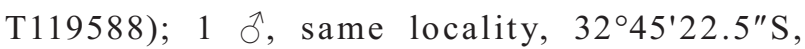


116 $17^{\prime} 30.4^{\prime \prime} E, 19$ August - 27 September 2011, wet pitfall trap, jarrah/marri, A. Scarfone (WAM T119595); 1 ग, same locality, 32॰41'43.9"S, 116²5'33.7"E, 19-23 August 2011, wet pitfall trap, pine plantation, A. Scarfone (WAM T119598); 1 त, 1 q, same locality, $32^{\circ} 39^{\prime} 52.3^{\prime \prime} \mathrm{S}, 116^{\circ} 25^{\prime} 8.8^{\prime \prime} \mathrm{E}, 19$ August - 27 September 2011, wet pitfall trap, jarrah/ marri, A. Scarfone (WAM T119602, T119603); 1 q, same locality, $32^{\circ} 39^{\prime} 45.3^{\prime \prime} \mathrm{S}, 116^{\circ} 23^{\prime} 31.7^{\prime \prime} \mathrm{E}, 23$ August 2011, hand collection, granite outcrop, A. Rakimov (WAM T119608); 1 juvenile, same locality, 32³9'5.6"S, 116 25'44.9"E, 23 August 2011, hand collection, pine plantation, A. Rakimov (WAM T119609); 1 ô, 3 ㅇ, same locality, 32³9'55.8"S, $116^{\circ} 25^{\prime} 43.3^{\prime \prime} \mathrm{E}, 23$ August 2011, hand collection, wandoo woodland, A. Rakimov (WAM T119610,

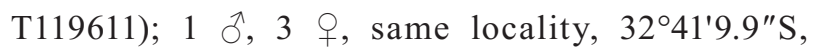
116 27'10.6"E, 17 August 2011, hand collection, granite outcrop, A. Rakimov (WAM T119615, T119616, T119619); 1 đ̃, same locality, 3241'22.5"S, $116^{\circ} 19^{\prime} 12.6^{\prime \prime} \mathrm{E}, 18$ August 2011, hand collection, wandoo woodland, A. Rakimov (WAM T119622); 1 ㅇ, same locality, 3243'13.9"S, $116^{\circ} 25^{\prime} 46.7^{\prime \prime} \mathrm{E}, 23$ August 2011, hand collection, wandoo woodland, A. Rakimov (WAM T119624); 2 옹, same locality, $32^{\circ} 38^{\prime} 01.3^{\prime \prime} \mathrm{S}, 116^{\circ} 26^{\prime} 24.5^{\prime \prime} \mathrm{E}, 23$ August 2011, hand collection, granite outcrop, A. Rakimov (WAM T119635, T119636); 1 ô, same locality, 32³8'01.3"S, 116²6'24.5"E, 19 August - 27 September 2011, wet pitfall trap, granite outcrop, A. Scarfone (WAM

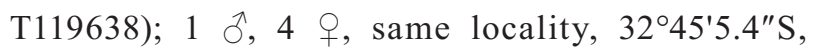
116²3'35.6"E, 19 August - 27 September 2011, wet pitfall trap, jarrah/marri, A. Scarfone (WAM T119645, T119647); 1 त, same locality, 32॰46'42.2"S, $116^{\circ} 19^{\prime} 49.5^{\prime \prime} \mathrm{E}, 20$ August 2011, hand collection, sheoak, A. Rakimov (WAM T 119650); 1 त, same locality, 3241'47.6"S, 116²0'01.7"E, 21 August 2011, hand collection, jarrah/marri, A. Rakimov (WAM T119664); 1옹 same locality, 32॰41'47.6"S, 116²0'01.7"E, 19 August - 27 September 2011, wet pitfall trap, jarrah/marri, A. Scarfone (WAM T119667); 1 q, 1 juvenile, same locality, 3240'45.4"S, $116^{\circ} 27^{\prime} 28^{\prime \prime}$ E, 21 August 2011, hand collection, wandoo woodland, A. Rakimov (WAM T119676); 1 q, same locality, 32॰39'52.3"S, $116^{\circ} 25^{\prime} 8.8^{\prime \prime} \mathrm{E}, 19$ August -27 September 2011, wet pitfall trap, jarrah/marri, A. Scarfone (WAM T119696); 1 ふै, Perth, Boya, 31'56'02.3"S, 11603'34.8"E, 14 September 2012, by hand, walking on path, C.A. Car (WAM T124438); 1 今, Thomsons Lake Nature Reserve, path south of Senecio Lane, $32^{\circ} 08^{\prime} 14^{\prime \prime}$ S, 11549'28"E, 6 June 2007, sifting leaf litter, M.G. Rix (WAM T124539); 1 స, Brookdale, $32^{\circ} 09^{\prime} 21^{\prime \prime} \mathrm{S}, 115^{\circ} 57^{\prime} 40^{\prime \prime} \mathrm{E}, 6$ September
2006, wet pitfall trap, Corymbia calaphylla, Melaleuca spp., J. Oats (WAM T126009); 1 ô, Buller Nature Reserve, $9.5 \mathrm{~km} \mathrm{SW}$. of Waroona, 32 $52^{\prime} 04^{\prime \prime} \mathrm{S}$, $15^{\circ} 49^{\prime} 43^{\prime \prime} \mathrm{E}, 22$ June 2007, sifting leaf litter, M.G. Rix (WAM T126026); 1 त, Gingin, Breera Rd, $31^{\circ} 26^{\prime} 50.4^{\prime \prime} \mathrm{S}, 115^{\circ} 57^{\prime} 03.9^{\prime \prime} \mathrm{E}, 14$ July 2012, by hand, leaf litter and grass, J. Foss (WAM T126033); 1 ô, $11.8 \mathrm{~km} \mathrm{NE}$. of New Norcia, 3054'50.01"S, $116^{\circ} 18^{\prime} 53.8^{\prime \prime} \mathrm{E}$, 13 September 2012, soil rake, leaf litter, T. Sachse (WAM T127011); 1 q, $19.2 \mathrm{~km} \mathrm{SE}$. of New Norcia, 31 $03^{\circ} 11^{\prime \prime} \mathrm{S}, 116^{\circ} 23^{\prime} 23^{\prime \prime} \mathrm{E}, 5$ October 2012, leaf litter rake, leaf litter, N. Watson (WAM T127304); 1 ㅇ, $11.5 \mathrm{~km} \mathrm{NE}$. of New Norcia, 30 $55^{\prime} 09^{\prime \prime} \mathrm{S}$, $116^{\circ} 18^{\prime} 52^{\prime \prime} \mathrm{E}, 5$ October 2012, pitfall trap, found in pit, N. Watson and S. Ford (WAM T127305); 1 q, $18.5 \mathrm{~km}$ SE. of New Norcia, $31^{\circ} 02^{\prime} 00^{\prime \prime} \mathrm{S}, 116^{\circ} 23^{\prime} 32^{\prime \prime} \mathrm{E}, 5$ October 2012, pitfall trap, found in pit, N. Watson and S. Ford (WAM T127306); 19, $19 \mathrm{~km} \mathrm{SE}$. of New Norcia, 31 ${ }^{\circ} 03^{\prime} 13^{\prime \prime} \mathrm{S}, 116^{\circ} 23^{\prime} 32^{\prime \prime} \mathrm{E}, 5$ October 2012, in bucket, N. Watson and S. Ford (WAM T127307); 1 , $19 \mathrm{~km}$ SE. of New Norcia, 31 $03^{\prime} 13^{\prime \prime} \mathrm{S}, 116^{\circ} 23^{\prime} 32^{\prime \prime} \mathrm{E}, 7$ October 2012, pitfall trap, found in pit, N. Watson and S. Ford (WAM T127308); 1 ô, Wooroloo Regional Park, nr junction of Cook /Neptune Rds, 31 $52^{\prime} 06^{\prime \prime} \mathrm{S}$, $116^{\circ} 13^{\prime} 21^{\prime \prime} \mathrm{E}, 3$ June 2013 , by hand, in very large fallen log, C.A. Car (WAM T130379); 4 ふ̂, 3 juveniles, Wooroloo Regional Park, nr junction of Cook / Neptune Rds, 31 $51^{\prime} 54^{\prime \prime} \mathrm{S}, 116^{\circ} 13^{\prime} 46^{\prime \prime} \mathrm{E}, 3$ June 2013, by hand, under bark pieces on ground, C.A. Car (WAM T130380); 1 $\widehat{o}$, between Omeo Road and Beraking Pool Roads, near Brookton Highway, 32¹2'12"S, $116^{\circ} 17^{\prime} 48^{\prime \prime}$ E, 28 September 2003, by hand, J.M. Waldock (WAM T73402); 1 juvenile, corner of Warradale Road and Brookton Highway, 32²3'20.53"S, 116 33'08.18"E, 8-13 September 2007, W. Bancroft (WAM T82727); 1 ふै, 1 , hill top, E. of Yarra Road, N. of Brookton Highway (site 4), $32^{\circ} 13^{\prime} 03^{\prime \prime} \mathrm{S}, 116^{\circ} 26^{\prime} 35^{\prime \prime} \mathrm{E}, 19$ September 2004, by hand, at base of Xanthorrhoea preissii, S. Slack-Smith (WAM T62599); 1 juvenile , 0.4 km N. of Brookton Highway on Yarra Rd, $32 \mathrm{~km}$ E. of Karragullen, $32^{\circ} 13^{\prime} 42.6^{\prime \prime} \mathrm{S}, 116^{\circ} 26^{\prime} 06.2^{\prime \prime} \mathrm{E}, 8$ June 2013 , by hand, in litter under low Xanthorrhea skirts, C.A. Car and J. M. Waldock (WAM T130383); 1 ô, Christmas Tree Well, Brookton Highway, $31.5 \mathrm{~km}$ E. of Karragullen, $32^{\circ} 13^{\prime} 39.4^{\prime \prime} \mathrm{S}, 116^{\circ} 25^{\prime} 20.2^{\prime \prime} \mathrm{E}, 8$ June 2013 , by hand, under bark litter, base of eucalypt, C.A. Car and J. M. Waldock (WAM T130384); 1 ઈ, 1 q, $2.18 \mathrm{~km} \mathrm{~N}$. of Brookton Highway on Yarra Rd, $32 \mathrm{~km} \mathrm{E.} \mathrm{of}$ Karragullen, 32¹3'40.8'S, 116²6'11.1"E, 8 June 2013, by hand, in deep litter, $2 \mathrm{~m}$ from marri tree, C.A. Car and J. M. Waldock (WAM T130386); 1 o, Boonanarring Nature Reserve, off Wannamal Rd 
West, 31 $10^{\circ} 28.7^{\prime \prime} \mathrm{S} 115^{\circ} 50^{\prime} 29.6^{\prime \prime} \mathrm{E}, 25$ May 2008, by hand, from leaf litter, J. M. Wojcieszek and M.G. Rix (WAM T130420); 1 §, Mt Frankland National Park, off Preston Rd, 3443'13.8"S, 116 $36^{\circ} 11^{\prime} 07^{\prime \prime}$ E, 28 June 2008, by hand, from leaf litter, J. M. Wojcieszek and M.G. Rix (WAM T130422); 1 ô, Unnamed Reserve, north of Manjimup, off Seaton Ross Rd, 34 $05^{\prime} 07.6^{\prime \prime} \mathrm{S}$, $116^{\circ} 11^{\prime} 03.0^{\prime \prime} \mathrm{E}, 29$ June 2008, by hand, from leaf litter, J. M. Wojcieszek and M.G. Rix (WAM T130425); 1 q, 10 miles E. of Northam, 31 $39^{\prime} \mathrm{S}, 116^{\circ} 50^{\prime} \mathrm{E}, 14$ September 1962, E.S. Ross and D.Q. Cavagnaro
(CAS); 3 o, 1 ㅇ, Mersea Forest', near Seaton Ross Road, $15 \mathrm{~km} \mathrm{~S}$. of Bridgetown along South-Western Highway, $34^{\circ} 05^{\prime} 08^{\prime \prime} \mathrm{S}, 116^{\circ} 11^{\prime} 04^{\prime \prime} \mathrm{E}, 2$ July 2009 , by hand, under logs, J.M. Wojcieszek and M.G. Rix (WAM T100206); 1 ㅇ, 13 miles W. of Bridgetown, $33^{\circ} 58^{\prime}$ S, $115^{\circ} 54^{\prime} \mathrm{E}, 25$ September 1962, E.S. Ross and D.Q. Cavagnaro (CAS); 1 ภ, Glen Forrest, 31 ${ }^{\circ} 54$ 'S, 116 $06^{\prime}$ E, 1971 - 1972, S.M. Wade (WAM T73133); 13

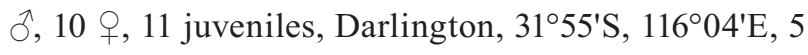
September 1962, E.S. Ross and D.Q. Cavagnaro (CAS). 
APPENDIX 2 All non-type material examined of Antichiropus whistleri.

Australia: Western Australia: 1 तै (gonopods only), Buckland Hill (near Fremantle), Hamburger südwestaustralischen Forschungsreise Station $114\left[32^{\circ} 03^{\prime} \mathrm{S}\right.$, $\left.115^{\circ} 44^{\prime} \mathrm{E}\right]$, date unknown, W. Michaelsen and R. Hartmeyer (NHMW 8071); 1 ô, 1 juvenile, Cottesloe [31 $\left.59^{\prime} \mathrm{S}, 115^{\circ} 45^{\prime} \mathrm{E}\right], 16$ June 1913, C. Drummond (WAM T290, T372); 3 Oे, Inglewood, site 1, 31 ${ }^{\circ} 55^{\prime} 04^{\prime \prime} \mathrm{S}$, $115^{\circ} 52^{\prime} 41^{\prime \prime} \mathrm{E}, 24-29$. August 1993, dry pitfall trap, N. Cooper (WAM T41670); 1 ô, Carabooda area, A. Lombardos property, Babylon Cave, YN-508, 31 ${ }^{\circ} 36^{\prime} \mathrm{S}$, $115^{\circ} 43^{\prime} \mathrm{E}, 26$ June 1999, by hand, dry sandy floor, twilight zone, R. Foulds (WAM T41837); 1 ふ઼, Kings Park, 31 $57^{\circ} \mathrm{S}, 115^{\circ} 50^{\prime} \mathrm{E}, 14$ June 2000, J.M. Waldock (WAM T42295); 1 ふै, Kings Park, near Saw Ave, $31^{\circ} 57^{\prime} \mathrm{S}, 115^{\circ} 50^{\prime} \mathrm{E}, 16$ June 2002 , by hand, M.S. Harvey et al. (WAM T46804); 7, 5 o, 1 juvenile, Innaloo, cycleway beside Mitchell Freeway between Lilacdale and Dunster Roads, 31 ${ }^{\circ} 53^{\prime} 08^{\prime \prime} \mathrm{S}, 115^{\circ} 48^{\prime} 01^{\prime \prime} \mathrm{E}, 3$ June 2003, by hand on path beside stunted marri trees, J.M. Waldock (WAM T53360-T53370); 1 స, Lake Gwelup Reserve, W. side of lake, $31^{\circ} 52^{\prime} 29^{\prime \prime}$ S, $115^{\circ} 47^{\prime} 19^{\prime \prime} \mathrm{E}, 5$ June 2003, by hand, on cement footpath in grassed area, J.M. Waldock (WAM T53595); 1 đૈ, E. edge of Star Swamp Nature Reserve, North Beach, 3151'17"S, $115^{\circ} 46^{\prime} 02^{\prime \prime} \mathrm{E}, 8$ June 2003, by hand on limestone footpath, J.M. Waldock (WAM T53596); 1 ふै, Trigg Dune Bush, site TD1, 31 $52^{\prime} 09^{\prime \prime} \mathrm{S}, 115^{\circ} 45^{\prime} 38^{\prime \prime} \mathrm{E}, 13$ July 25 September 1995, wet pitfall trap, M.S. Harvey and J.M. Waldock(WAM T72796); 1 ô, Dianella Open Space, sites DO1, DO2, 31 ${ }^{\circ} 53^{\prime} \mathrm{S}, 115^{\circ} 50^{\prime} \mathrm{E}, 14$ November -11 December 1994, dry pitfall trap, N. Cooper (WAM T72797); 4 ふૈ, 3 ᄋ, 1 juvenile, Warwick Open Space, site WR2, 31 $50^{\prime} 33^{\prime \prime}$ S, $115^{\circ} 49^{\prime} 00^{\prime \prime}$ E, 13 July - 25 September 1995, wet pitfall trap, M.S. Harvey and J.M. Waldock

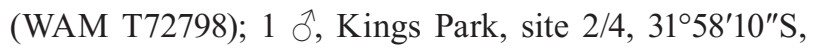
11549'00"E, 23 July 1992, pitfall trap, J. Dell (WAM T72799); 1 ô, Kings Park, site 3/9, 3158'15"S, 11549'20"E, 23 July 1992, pitfall trap, J. Dell (WAM

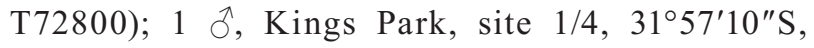
11549'55"E, 24 April 1993, pitfall trap, J. Dell (WAM T72801); 1 ô, 1 , Landsdale Farm School, site LS1, $31^{\circ} 49^{\prime} 14^{\prime \prime} \mathrm{S}, 115^{\circ} 51^{\prime} 01^{\prime \prime} \mathrm{E}, 1-15$ October 1995 , dry pitfall trap, J. Dell (WAM T72802); 3 ô, Landsdale Farm School, site LS1, 31 $49^{\prime} 14^{\prime \prime}$ S, $115^{\circ} 51^{\prime} 01^{\prime \prime}$ E, 13 July - 25 September 1995, wet pitfall trap, M.S. Harvey and J.M. Waldock (WAM T72803, T72804, T73255); 1 o, Tuart Hill, site TH3, 31 $52^{\prime} 50^{\prime \prime} \mathrm{S}, 115^{\circ} 51^{\prime} 34^{\prime \prime} \mathrm{E}, 10$ May - 20 July 1993, wet pitfall trap, M.S. Harvey and J.M. Waldock (WAM T72832); 1 ふ઼, Tuart Hill, site TH1, 31'52'49"S, 11551'30"E, 18-31 October 1993, H. Cooper
(WAM T72833); 1 §ิ, 1 , 24 September - 18 November 1993, same details, wet pitfall trap, J.M. Waldock et al. (WAM T72834); 3 ふै, same details, 10 May - 20 July 1993, wet pitfall trap, M.S. Harvey and J.M. Waldock (WAM T72835); 1 ふै, 2 o, 1 juvenile, Tuart Hill, site TH2, 31 $52^{\prime} 50^{\prime \prime}$ S, 115 51'32"E, 20 July - 23 September 1993, wet pitfall trap, J.M. Waldock, A. Sampey and A. Thorpe (WAM T72836); 3 ô, 3 q, 4 juveniles, Tuart

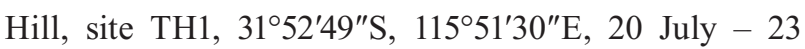
September 1993, wet pitfall trap, J.M. Waldock, A. Sampey and A. Thorpe (WAM T72837); 1 ふै, 1 ㅇ,

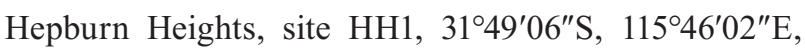
1-15 October 1995, dry pitfall trap, J. Dell (WAM T72838); 1 ふै, 1 ㅇ, Hepburn Heights, site HH2, $31^{\circ} 49^{\prime} 07^{\prime \prime} \mathrm{S}, 115^{\circ} 46^{\prime} 11^{\prime \prime} \mathrm{E}, 1-15$ October 1995, dry pitfall trap, J. Dell (WAM T72839); 7 đ, Hepburn Heights, site HH3, 31 $49^{\prime} 02^{\prime \prime}$ S, $115^{\circ} 46^{\prime} 13^{\prime \prime}$ E, 13 July - 25 September 1995, wet pitfall trap, M.S. Harvey and J.M. Waldock (WAM T72840, T72841, T73246, T73237,T73247-9); 2

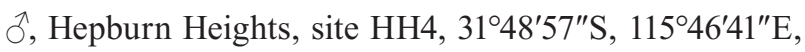
13-25 July 1995, wet pitfall trap, M.S. Harvey and J.M. Waldock (WAM T72842, T72843); 1 O̊, same details, 25 September - 28 November 1995 (WAM T73251) ; 4 ふै, 2

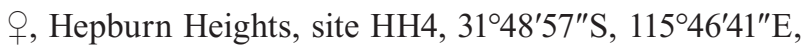
1-15 October 1995, dry pitfall trap, J. Dell (WAM T72844); 1 ô, Marangaroo Reserve, site MR1, 31 499'51"S, 11550'03"E, 13 July - 25 September 1995, wet pitfall trap, M.S. Harvey and J.M. Waldock (WAM T72845); 1 ô, Marangaroo Reserve, site MR2

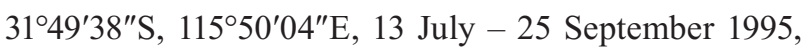
wet pitfall trap, M.S. Harvey and J.M. Waldock (WAM T72846); 1 ô, Gnangara, 314ㅇ's, $115^{\circ} 52^{\prime} \mathrm{E}, 27$ November 1969, pitfall trap, J.A. Springett (WAM T72847); 1 ô, Shenton Bush, site B, 31 $57^{\prime} 45.8^{\prime \prime} \mathrm{S}$, $115^{\circ} 47^{\prime} 53.7^{\prime \prime} \mathrm{E}$, September 1998, dry pitfall traps P. Berry (WAM T73134); 5 § Hepburn Heights, site HH4, 31 48'57"S, 11546'41"E, 13 July - 25 September 1995, wet pitfall trap, M.S. Harvey and J.M. Waldock (WAM T73236, T73250, T73252-4); 1 ô, same details, 25 September - 28 November 1995 (WAM T73251); 1 ઈ Burns Beach, 4 km ESE., 31 $45^{\circ} \mathrm{S}, 115^{\circ} 45^{\prime} \mathrm{E}, 21$ June 1977, collected by hand, active on limestone 'KunKar' in open heath, A. Chapman (WAM T73238); 2 q, 2 juveniles, Shenton Bush, site A, 31 $57^{\prime} 52.5^{\prime \prime} \mathrm{S}$, $115^{\circ} 47^{\prime} 57^{\prime \prime}$, September 1998, dry pitfall traps, P. Berry (WAM T73240); 1 ô, Reabold Hill, site RH 6, 31 ${ }^{\circ} 57^{\prime}$ S, $115^{\circ} 46^{\prime} \mathrm{E}, 21-28$ July 1976, pitfall trap, J.D. Majer (WAM T73241); 2 ภ, 2 , 1 juvenile, Reabold Hill, 3157'S, $115^{\circ} 46^{\prime}$ E, 12 April 1968, by hand, E.G. Cockett (WAM T73242); 1 ऽे, Yanchep National Park, on track between 
caves $\mathrm{YN}-14$ and $\mathrm{YN}-18,31^{\circ} 35^{\prime} \mathrm{S}, 115^{\circ} 40^{\prime} \mathrm{E}, 16$ September 2000, by hand, in hole in track, R. Foulds (WAM T73243); 1 స, 1 , 2 juveniles, Reabold Hill, site RH 6, 31 ${ }^{\circ} 57^{\prime} \mathrm{S}, 115^{\circ} 46^{\prime} \mathrm{E}, 21-28$ July 1976 , pitfall trap, J.D. Majer (WAM T73244); 2 o, 1 juvenile, Gnangara, site $2,31^{\circ} 50^{\prime} \mathrm{S}, 115^{\circ} 50^{\prime} \mathrm{E}, 21$ July 1970 , pitfall trap, J.A. Springett (WAM T73245); 1 ô, Neerabup National Park, $31^{\circ} 39^{\prime} \mathrm{S}, 115^{\circ} 43^{\prime} \mathrm{E}, 18$ May - 1 June 1977, G. Barron and

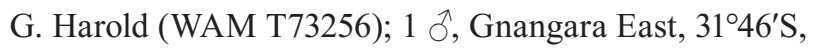
$115^{\circ} 54^{\prime} \mathrm{E}$, 8 June 1969, by hand, A.M. Douglas (WAM T73257) 1 đ,, 2 q, 1 juvenile, same details 10 June 1969

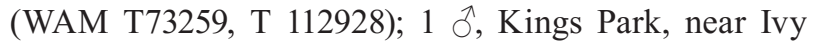
Watson playground, $31^{\circ} 58^{\prime} \mathrm{S}, 115^{\circ} 50^{\prime} \mathrm{E}, 19$ July 1998 , by hand, on grass in daytime, M.S. Harvey (WAM T73258); 1 ô, 1 juvenile, Along road between Burns Beach and Wanneroo Road, half a mile along track to south, $31^{\circ} 45^{\prime} \mathrm{S}, 115^{\circ} 45^{\prime} \mathrm{E}, 2$ June 1975 , by hand, tuart and banksia bushland, S. Slack-Smith (WAM T73260); 1 ô, 2 \%, Perth, 31 ${ }^{\circ} 57^{\prime} \mathrm{S}, 115^{\circ} 51^{\prime} \mathrm{E}, 1976$, by hand, J.D. Majer (WAM T73261); 10 ๙ै, 1 q, Kings Park, Perth, 31'57'24"S, 11549'39"E, 14 June 2000, by hand, on cycleway in rain, J.M. Waldock (WAM T73383, T73389); 1 §, Cooljarloo, $260 \mathrm{~km} \mathrm{~N}$. of Perth, 30³9'S, $115^{\circ} 22^{\prime} \mathrm{E}$, September 2009, M. Bamford (WAM

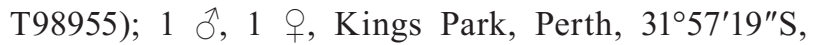
$115^{\circ} 50^{\prime} 00^{\prime \prime}$ E, 7 June 2007, by hand, under log, M.G. Rix (WAM T100204, T100205); 1 ઈ, 1 क, Pearce Airforce Base, $31^{\circ} 31^{\prime} 14.64^{\prime \prime} \mathrm{S}, 116^{\circ} 01^{\prime} 49.32^{\prime \prime} \mathrm{E}, 23$ June -8 August 2008, wet pitfall trap, J. Nolthenous and F. Bochari
(WAM T109215); 3 ふै, Craigie Open Space, near

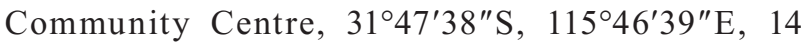
September 2010, by hand, C.A. Car (WAM T112618, T111733); 2 ふै, Innaloo, cycleway crossing over Mitchell freeway, near Hertha Rd, 31 $53^{\prime} 21^{\prime \prime} \mathrm{S}, 115^{\circ} 48^{\prime} 06^{\prime \prime} \mathrm{E}, 4$ June 2003, J.M. Waldock (WAM T53371, T112926); 1 ô, Kings Park, Perth, along bike path W. of May Drive, 31 57'32"S, 115 49'37"E, 10 September 2011, by hand, on bike path, M.G. Rix and J.M. Wojcieszek (WAM T116229); 4 गे, Waterman, Star Swamp, 31 $50^{\prime} 35^{\prime \prime} \mathrm{S}$, $115^{\circ} 45^{\prime} 42^{\prime \prime}$ E, 24 August 2010, by hand, C.A. Car (WAM T111732, T117505); 1 क, Just east of Nilgen Nature Reserve, adjacent to Sappers Rd, $31^{\circ} 01^{\prime} 08^{\prime \prime} \mathrm{S}$, $115^{\circ} 25^{\prime} 04^{\prime \prime} \mathrm{E}, 14$ June 2007, sifting leaf litter, M.G. Rix (WAM T124581); 1 $\hat{\sigma}$, Lake Pinjar wetlands, north-east of Joondalup, $31^{\circ} 37^{\prime} 42^{\prime \prime} \mathrm{S}, 115^{\circ} 48^{\prime} 35^{\prime \prime} \mathrm{E}, 10$ June 2009, hand collected in leaf litter, A. Silla (WAM T126014); 1 o, same details, 3 June 2009, (WAM T126085); 2 o, 3 +, $4 \mathrm{~km}$ SSE. of Cooljarloo, Cooljarloo South Mine, $30^{\circ} 41^{\prime} 00^{\prime \prime} \mathrm{S}, 115^{\circ} 25^{\prime} 00^{\prime \prime} \mathrm{E}, 1$ September 2012, M. Bamford (WAM T126884); 1 ग̃, 1 †, $34 \mathrm{~km} \mathrm{E.} \mathrm{of}$ Cooljarloo, Cooljarloo Falcon Mine, 30³5'00"S, $115^{\circ} 44^{\prime} 00^{\prime \prime} \mathrm{E}$, 1 September 2012, M. Bamford (WAM T126886); 2 §ै, 3 juveniles, Cooljarloo, $10 \mathrm{~km} \mathrm{~N}$. of Cataby, 30³7'30"S, $115^{\circ} 24^{\prime} 58^{\prime \prime} \mathrm{E}, 10$ August 2011, M. Bamford (WAM T129424, T129425); 2 ふૈ, Yellagonga Regional Park, Perth, Joondalup, 31 43'36"S, $115^{\circ} 47^{\prime} 05^{\prime \prime} \mathrm{E}, 26$ May 2013, hand collected, walking on path near pine plantation, C.A. Car (WAM T130172). 